
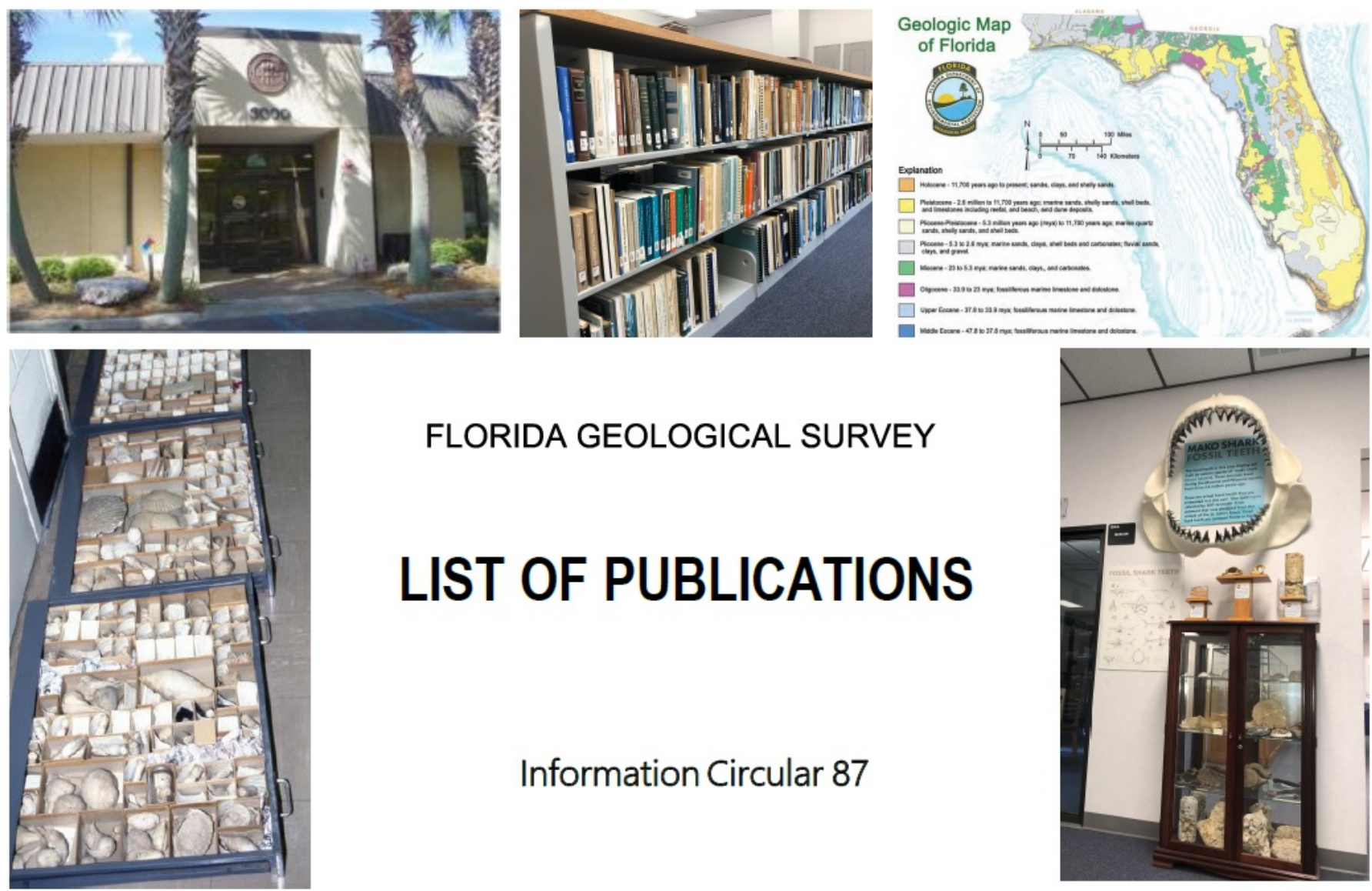

FLORIDA GEOLOGICAL SURVEY

\title{
LIST OF PUBLICATIONS
}

Information Circular 87
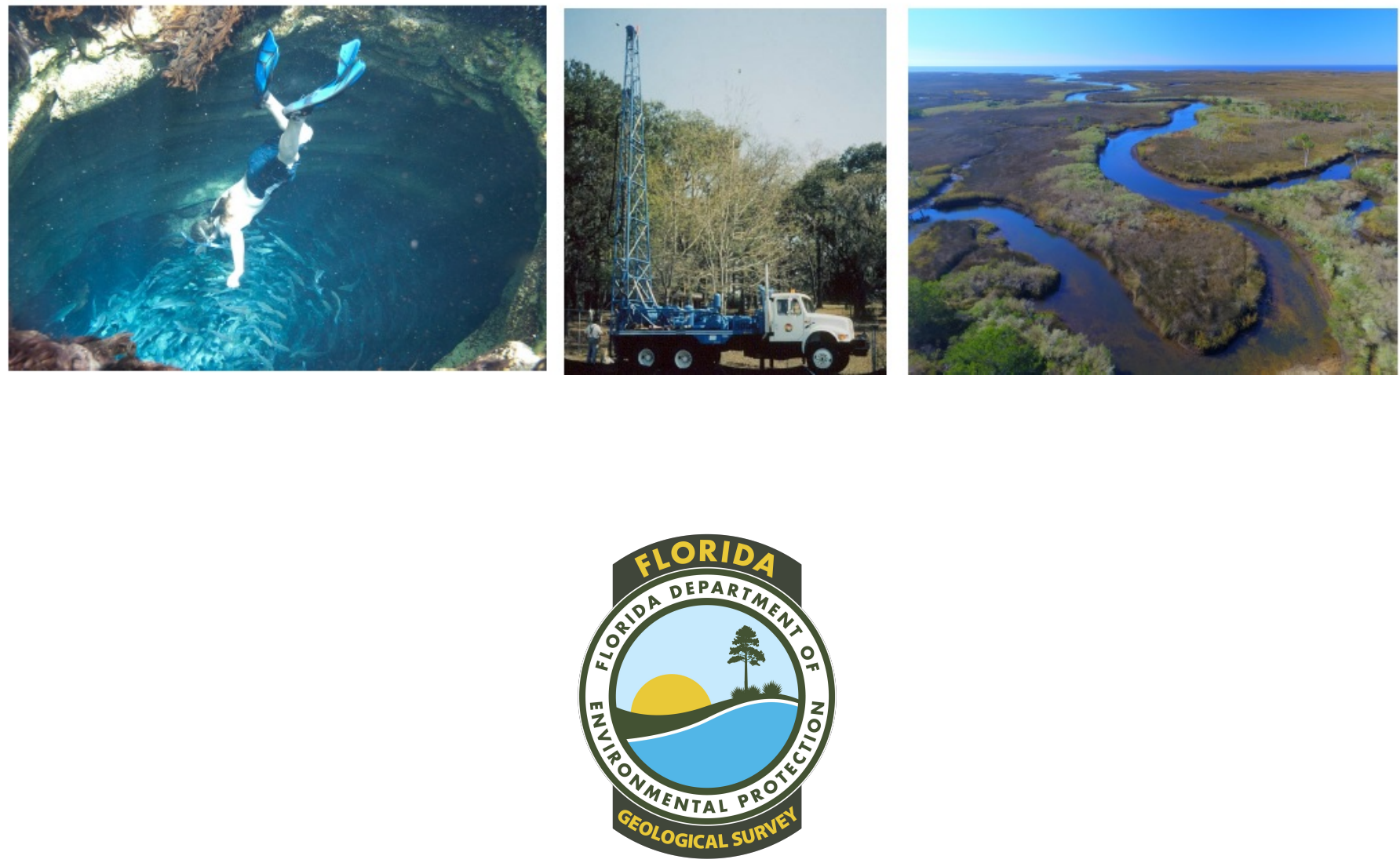

Tallahassee, Florida 2022 
Cover-- Clockwise from top left:

1. FGS headquarters building.

2. FGS Research Library.

3. FGS Geologic Map of Florida postcard.

4. Walter Schmidt Museum of Florida Geology.

5. Big Spring Creek from above, January 2016.

6. Drill rig in the field, Hernando county.

7. Diving into vent at Silver Glen Spring.

8. FGS Invertebrate Collection.

\section{Counties of Florida}

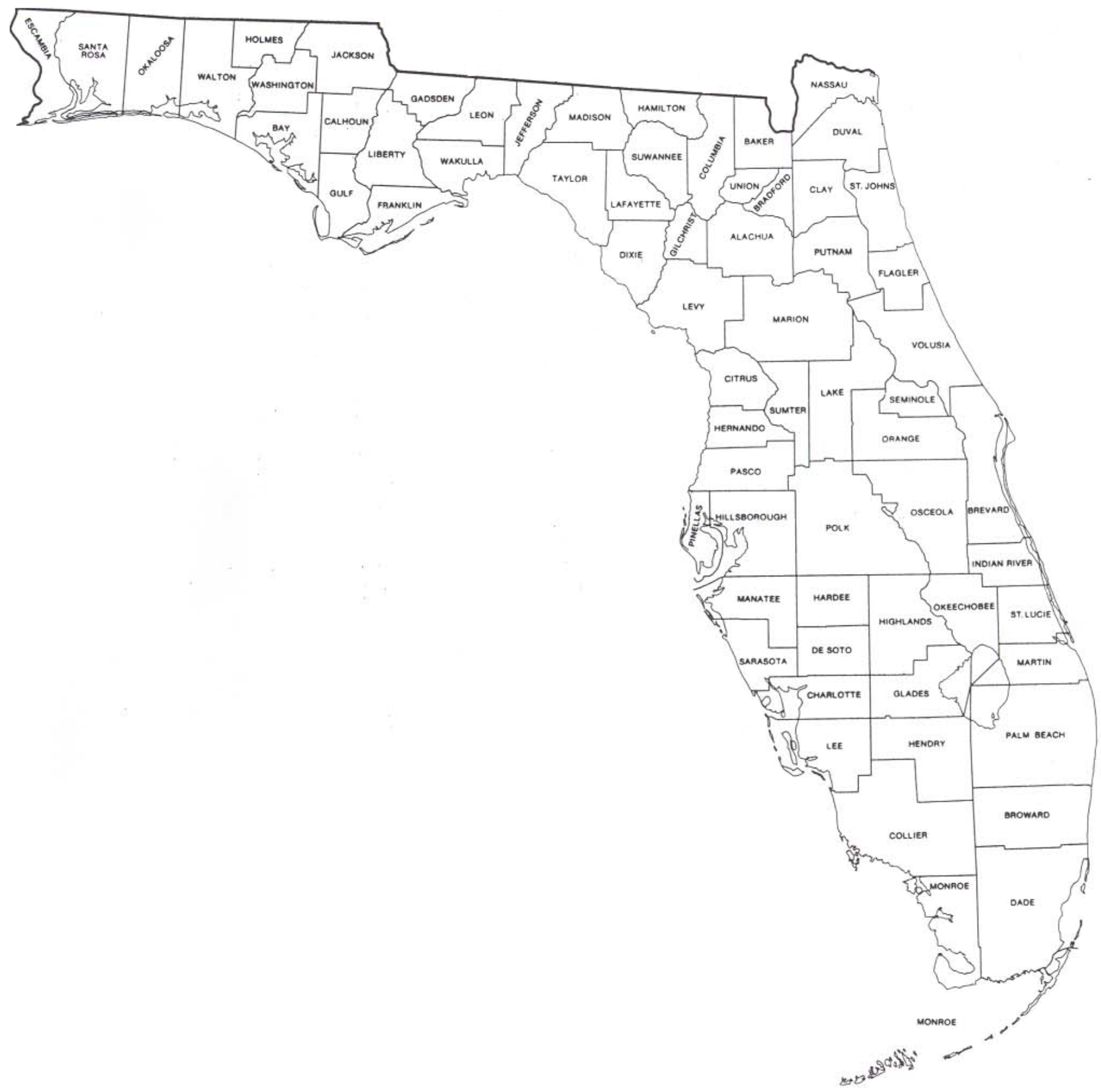




\section{STATE OF FLORIDA}

\section{DEPARTMENT OF ENVIRONMENTAL PROTECTION}

\section{REGULATORY PROGRAMS}

\section{FLORIDA GEOLOGICAL SURVEY}

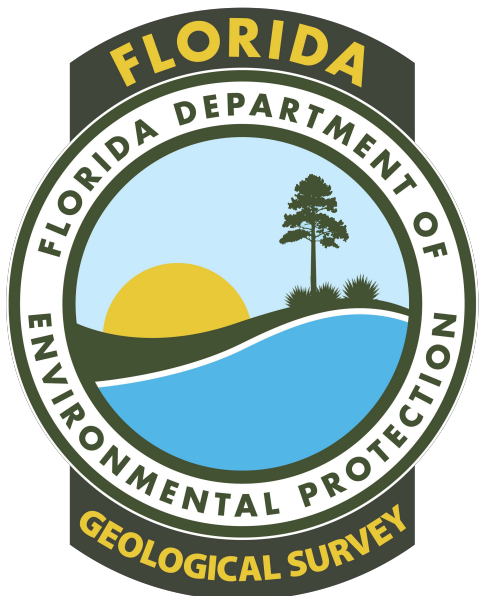

Information Circular 87

\section{List of Publications}

Edited by: Doug Calman, Frank Rupert, and Kathryn Etheridge

2022 Edition

ISSN 0085-0616 


\section{CONTENTS}

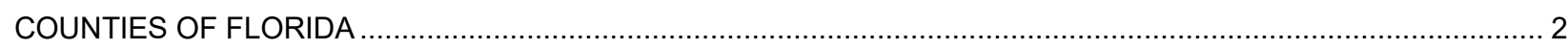

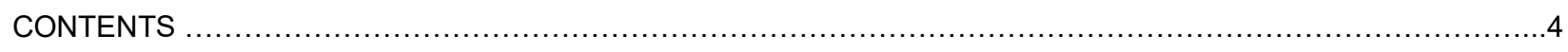

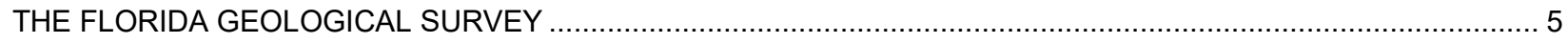

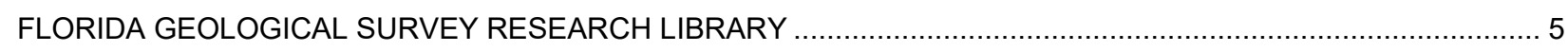

PUBLICATIONS OF THE FLORIDA GEOLOGICAL SURVEY ON THE WEB ….............................................. 5

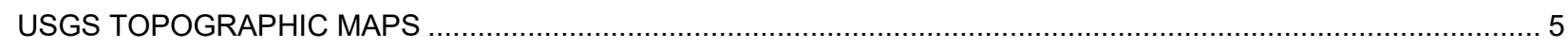

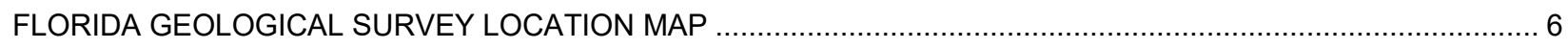

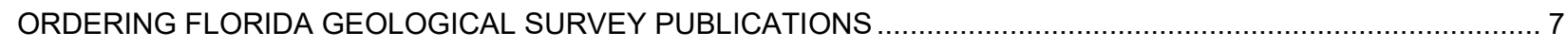

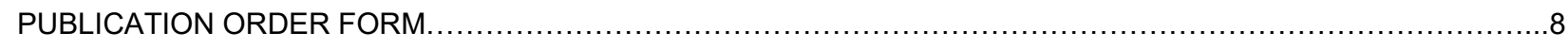

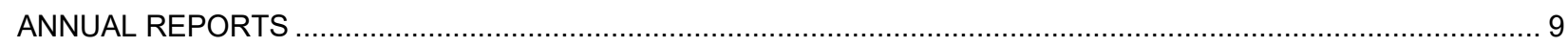

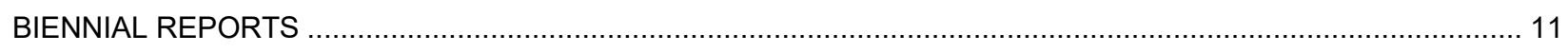

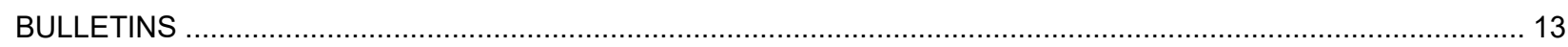

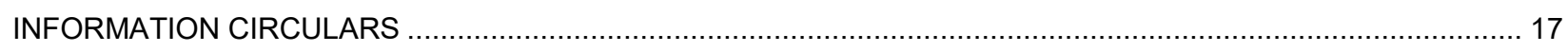

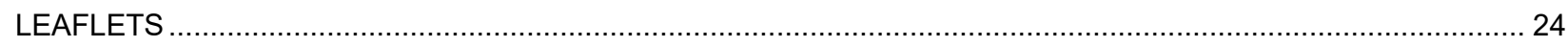

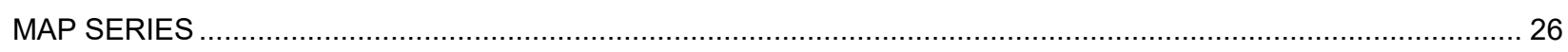

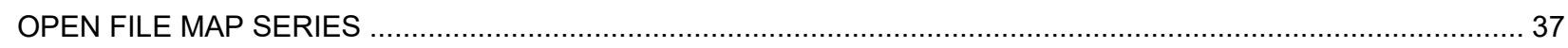

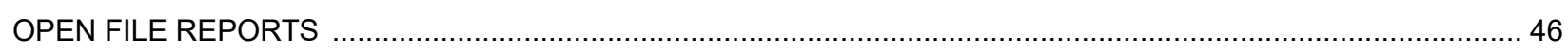

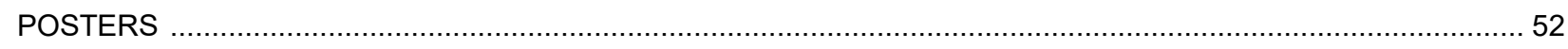

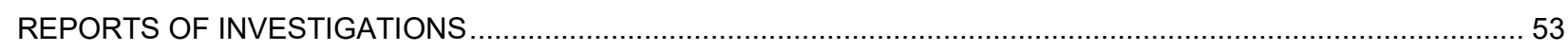

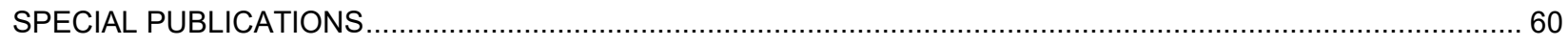

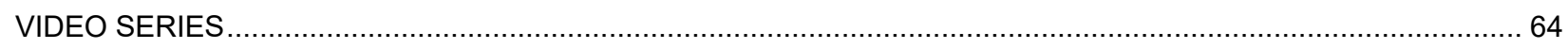

INDEX

LIBRARIES HOLDING OUT-OF-PRINT FLORIDA GEOLOGICAL SURVEY PUBLICATIONS............................... 74

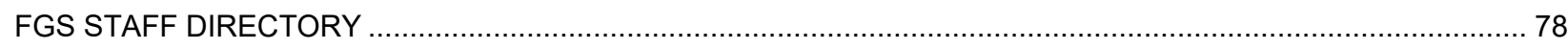




\section{THE FLORIDA GEOLOGICAL SURVEY}

The Florida Geological Survey (FGS) is an office under Regulatory Programs, in the Florida Department of Environmental Protection. The mission of the FGS is to collect, interpret and provide objective quality geologic information about Florida. Additional information about the programs of the FGS may be obtained from our website at:

http://www.dep.state.fl.us/geology/default.htm

\section{FLORIDA GEOLOGICAL SURVEY RESEARCH LIBRARY}

The FGS library provides access to basic research materials, including books, state and federal documents, maps, photographs and periodicals. Materials are collected on various aspects of geology, including mining and mineral resources, environmental geology, hydrogeology, coastal geology and other related topics. The library is open to the public and is frequently used by students, private consulting firms, various governmental agencies and the general public. The library also provides detailed information on the FGS's more than 700 published documents and reports, and oversees the distribution of those documents currently in print.

\section{PUBLICATIONS OF THE FLORIDA GEOLOGICAL SURVEY ON THE WEB}

Visit our website at: http://www.dep.state.fl.us/geology/publications/listofpubs.htm.

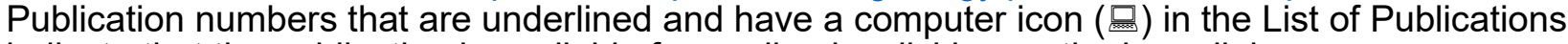
indicate that the publication is available free online by clicking on the hyperlink.

\section{USGS TOPOGRAPHIC MAPS}

The Florida Geological Survey does not distribute Florida topographic maps. Topographic maps are prepared by the U.S. Geological Survey and information on pricing and ordering is available from the USGS at:

USGS Information Services

Box 25286

Denver, CO 80225

Phone 1 -888-ASK-USGS or 1-303-202-4700 Fax: 1-303-202-4693

Information on identifying and ordering topographic maps may also be obtained at the USGS website:

\section{http://www.usgs.gov/pubprod/}

Information regarding local Florida distributors of USGS maps may be obtained through the links provided at the site above or by consulting your local yellow pages for commercial dealers that sell USGS maps and contacting them directly for pricing and ordering information. 


\section{FLORIDA GEOLOGICAL SURVEY LOCATION MAP}

The Florida Geological Survey Library is located at our new main headquarters building, 3000 Commonwealth Boulevard, in northwest Tallahassee. From I-10 exit 196 proceed south on Capital Circle NW approximately 0.2 miles. Turn east onto Commonwealth Boulevard. Continue 0.5 miles to FGS headquarters on the left.
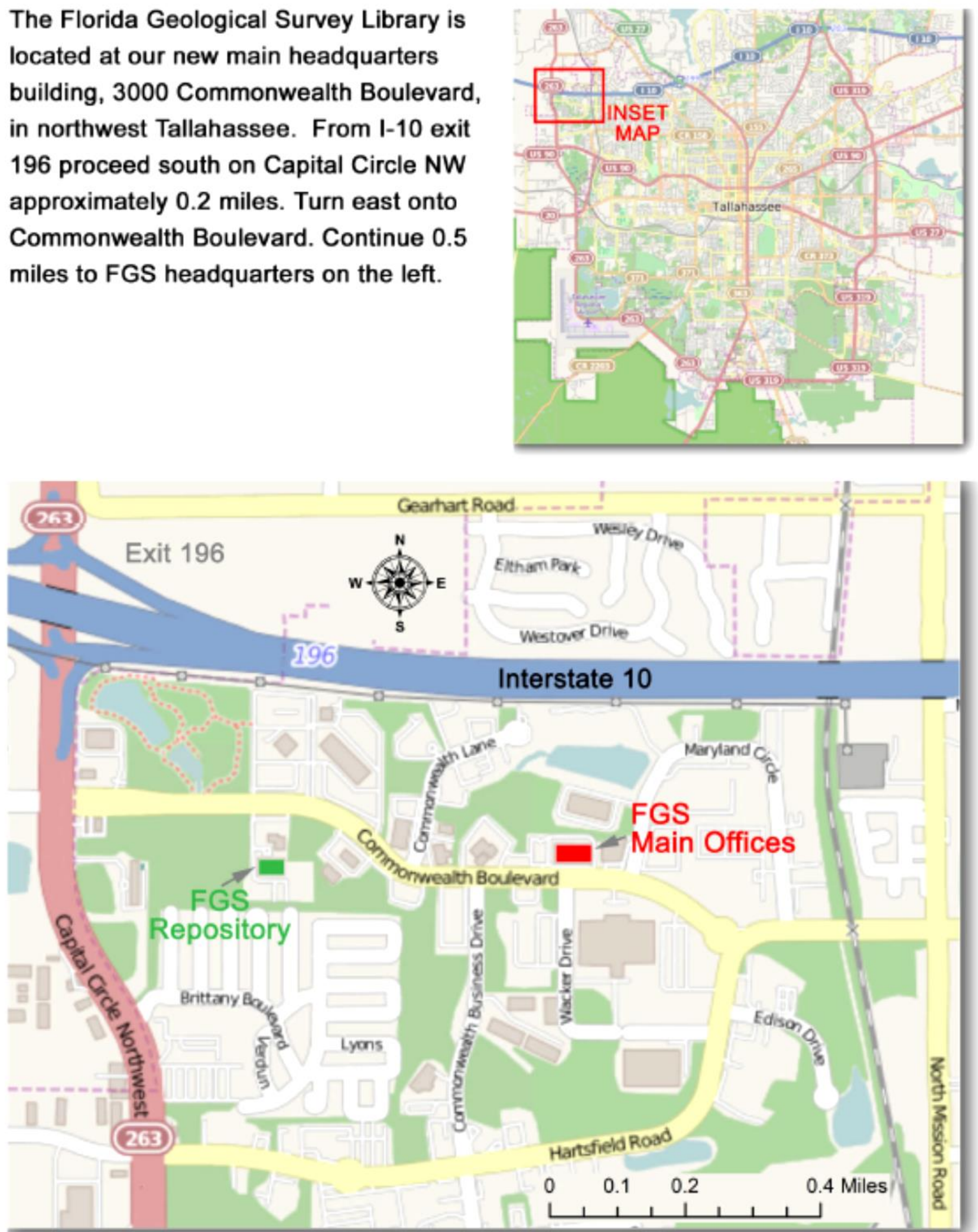


\section{ORDERING FLORIDA GEOLOGICAL SURVEY PUBLICATIONS}

\section{Full text of some Publications available online - FREE}

Hyperlinks in the online List of Publications (Information Circular 87) indicate that the full publication has been scanned into a PDF or HTML file and is available by clicking on the hyperlink. You may then read it online, or print it at no charge.

\section{Address all orders and correspondence to:}

Publications Office Florida Geological Survey

3000 Commonwealth Blvd., Suite 1, Tallahassee, FL 32303-3157,

Phone No. 850/617-0316

PAYMENT TERMS: Pre-payment is required on all orders. Checks or money orders are accepted. No credit card orders. Make checks/money-orders payable to "Florida Department of Environmental Protection." Due to limited supply, in-print orders are limited to five copies per title.

\section{SHIPPING AND HANDLING:}

In addition to the list price, please add shipping and handling charges as follows. Shipping charges for free posters will be a minimum of $\$ 4.00$ per order to cover the cost of mailing tubes and postage.

\begin{tabular}{|lr|rr|}
\hline Orders of: & add: & Orders of: & add: \\
\hline up to $\$ 2.00$ & $\$ 1.00$ & $\$ 12.01-20.00$ & $\$ 5.00$ \\
$2.01-4.00$ & 2.00 & $20.01-50.00$ & 7.00 \\
$4.01-8.00$ & 2.50 & $50.01-100.00$ & 10.00 \\
$8.01-12.00$ & 3.00 & 100.01 and up & 15.00 \\
\hline
\end{tabular}

\section{TO SPEED PROCESSING:}

Use the order form on the next page. Specify series name and number of publications. Examples: Bulletin 43, B-43. Do not order multiple copies of a document. Do not order out-of-print publications.

\section{OUT-OF-PRINT PUBLICATIONS:}

Out of print publications are not available for purchase. Try interlibrary loan through your local public library. FGS documents are becoming increasingly available on the Internet. Check the UF Libraries site at http://ufdc.ufl.edu/fgs.

Write to the Library / Publications Office of the Florida Geological Survey at the above address if a copy of an out-of-print document cannot be located.

\section{REFUNDS:}

Incorrect checks or money orders cannot be returned due to Department policy. All monies received by the Department must be deposited upon receipt. If a refund is necessary, arrangements will be made through the Publications Office. Following the ordering guidelines above will help eliminate delays in processing.

\section{GIFT/EXCHANGE PROGRAM:}

Send on school letterhead. College, University and Public libraries are eligible to enter the Florida Geological Survey's Gift/Exchange program. State government agencies in Florida may receive a complimentary copy of available publications.

Please contact the FGS Library / Publications Office for further details of the Gift/Exchange program. 


\section{PUBLICATION ORDER FORM}

For a fillable online form see: http://www.dep.state.fl.us/geology/publications/pub_order_form.pdf

Name

Company

Address

City State ZIP

Telephone E-Mail

\begin{tabular}{|c|c|c|c|}
\hline Qty. & $\begin{array}{l}\text { Series and } \\
\text { Number }\end{array}$ & Title (abbreviate) & Price \\
\hline 1 & & & \\
\hline 1 & & & \\
\hline 1 & & & \\
\hline 1 & & & \\
\hline 1 & & & \\
\hline 1 & & & \\
\hline 1 & & & \\
\hline 1 & & & \\
\hline 1 & & & \\
\hline 1 & & & \\
\hline & & Subtotal & \\
\hline & & Shipping and Handling (see chart below) & \\
\hline & & Total Amount Enclosed & \\
\hline
\end{tabular}

-LIMIT FIVE COPIES PER DOCUMENT (IN-PRINT ITEMS ONLY) -PREPAYMENT REQUIRED

-MAKE CHECKS/MONEY ORDERS PAYABLE TO

FL DEPARTMENT OF ENVIRONMENTAL PROTECTION

-Address Order to:

PUBLICATIONS OFFICE

FLORIDA GEOLOGICAL SURVEY

3000 COMMONWEALTH BLVD., SUITE 1 TALLAHASSEE, FL

32303-3157

(850) 617-0316

Shipping and Handling Orders of:

up to $\$ 2.00$

add

2.01-4.00

1.00

4.01-8.00

2.00

2.50

8.01-12.00

3.00

12.01-20.00

5.00

20.01-50.00

7.00

50.01-100.00

10.00

100.01 and up 


\title{
ANNUAL REPORTS
}

\begin{abstract}
Annual Reports (AR) record the results of geologic investigations and include administrative information of the Florida Geological Survey, including budget, staff lists, and facilities. Annual Reports ceased to be published in 1933.
\end{abstract}

\section{AR 1 믈 OUT OF PRINT}

First Annual Report, 1907-08, by E.H. Sellards, 1908, 114 p., 6 pl. Contains (1) a sketch of the geology of Florida, (2) mineral industries, including phosphate, kaolin ball clay, brick-making clays, fullers earth, peat, lime, cement, and roadmaking materials, (3) a bibliography of Florida geology.

\section{AR 2 믈 OUT OF PRINT}

Second Annual Report, 1908-09; 1909, 299 p., 19 pl., 5 fig., 1 map. Contains (1) a preliminary report on the geology of Florida, with special reference to stratigraphy, including a topographic and geologic map of Florida, (2) mineral industries, (3) the fullers earth deposits of Gadsden County, with notes on similar deposits found elsewhere in the state.

\section{AR 3 믈 OUT OF PRINT}

Third Annual Report, 1909-1910; 1910, 397 p., 30 fig. Contains (1) Preliminary Paper on the Florida Phosphate Deposits, (2) Some Florida Lakes and Lake Basins, (3) The Artesian Water Supply of Eastern Florida, (4) A Preliminary Report on the Florida Peat Deposits.

\section{AR 4 믈 OUT OF PRINT}

Fourth Annual Report, 1910-11; 1912, 175 p., 16 pl., 15 fig., 1 map. Contains (1) The Soils and Other Surface Residual Materials of Florida, (2) The Water Supply of West-Central and West Florida, (3) Production of Phosphate Rock and Fullers Earth in Florida During 1910 and 1911.

\section{AR 5 믈 OUT OF PRINT}

Fifth Annual Report, 1913, 306 p., 14 pl., 17 fig., 2 maps. Contains (1) Origin of the Hard Rock Phosphates of Florida, (2) List of Elevations in Florida, (3) Artesian Water Supply of Eastern and Southern Florida, (4) Production of Phosphate in Florida During 1912, (5) Statistics on Public Roads in Florida.

\section{AR 6 믈 OUT OF PRINT}

Sixth Annual Report, 1914, 451 p., 90 fig., 1 map. Contains (1) Mineral Industries and Resources of Florida, (2) Some Florida Lakes and Lake Basins, (3) The Relation Between the Dunnellon Formation and the Alachua Clays, (4) Geography and Vegetation of Northern Florida.

\section{AR 7 OUT OF PRINT}

Seventh Annual Report, 1915, 342 p., 80 fig., 4 maps. Contains (1) Statistics on Mineral Industries of Florida for the Calendar Year, 1914, (2) The Pebble Phosphates of Florida, (3) The Natural Resources of an Area in Central Florida, Including a Part of Marion, Levy, Citrus and Sumter Counties, (4) Soil Survey of Bradford County, (5) Soil Survey of Pinellas County.

\section{AR 8 믐 OUT OF PRINT}

Eighth Annual Report, 1916, 168 p., 31 pl., 14 fig. Contains (1) Mineral Industries of Florida During 1915, (2) Description of Some Florida Fossil Vertebrates, Belonging Mostly to the Pleistocene, (3) Fossil Vertebrates from Florida; A New Miocene Fauna; New Pliocene Species; The Pleistocene Fauna, (4) Human Remains and Associated Fossils from the Pleistocene of Florida. https://doi.org/10.35256/AR08.

\section{AR 9 믐 OUT OF PRINT}

Ninth Annual Report, 1917, 151 p., 8 pl., 13 fig., 2 maps. Contains (1) Mineral Industries of Florida During 1916, (2) Additional Studies in the Pleistocene at Vero, Florida, (3) Geology Between the Ocklocknee (sic) and Aucilla Rivers in Florida. https://doi.org/10.35256/AR09.

\section{AR 10/11 9 OUT OF PRINT}

Tenth and Eleventh Annual Reports, 1918, 130 p., 4 pl., 9 fig., 2 maps. Contains (1) Geology Between the Apalachicola and Ocklocknee Rivers, (2) The Skull of a Pleistocene Tapir Including Description of a new Species and a Note on the Associated Fauna and Flora, (3) Geology Between the Choctawhatchee and Apalachicola Rivers, (4) Statistics on Mineral Production in Florida During 1917, (5) Molluscan Fauna from the Calcareous Marls in the Vicinity of DeLand, Volusia County, Florida. 


\section{AR 12 믐 OUT OF PRINT}

Twelfth Annual Report, 1919, 153 p., 4 maps. Contains (1) Literature Relating to Human Remains and Artifacts at Vero, Florida, (2) Fossil Beetles from Vero, Florida, (3) Elevations in Florida, (4) Geologic Section Across the Everglades of Florida, (5) The Age of the Underlying Rocks of Florida as Shown by the Foraminifera of Well Borings, (6) Review of the Geology of Florida with Special Reference to Structural Conditions.

\section{AR 13 믕 OUT OF PRINT}

Thirteenth Annual Report, 1921, 307 p., 43 fig. Contains (1) Oil Prospecting in Florida, (2) Statistics of Mineral Production, in Florida, 1918, (3) Foraminifera from the Deep Wells of Florida, (4) Geography of Central Florida.

\section{AR 14 므 OUT OF PRINT}

Fourteenth Annual Report, 1921-1922; 1922, 135 p., 10 fig., 1 map. Contains (1) Mineral Production in Florida During 1919, (2) Statistics on Mineral Production During 1920, (3) On the Petroleum Possibilities of Florida, (with a geologic map).

\section{AR 15 믕 OUT OF PRINT}

Fifteenth Annual Report, 1922-1923; 1924, 266 p., 2 pl., 55 fig. Contains (1) Statistics on Mineral Production in Florida During 1921 and 1922, (2) A Contribution to the Late Tertiary and Quaternary Paleontology of Northeastern Florida, (3) A Preliminary Report on Clays of Florida.

\section{AR 16 믐 OUT OF PRINT}

Sixteenth Annual Report, 1923-1924; 1925, 203 p., 52 fig., 2 maps. Contains (1) Statistics on Mineral Production in Florida During 1923, (2) A Preliminary Report on the Limestones and Marls of Florida.

\section{AR 17 믐 OUT OF PRINT}

Seventeenth Annual Report, 1924-1925; 1926, 275 p., 5 fig., 2 maps. Contains (1) Statistics of Mineral Production in Florida During 1924, (2) History of Soil Investigation in Florida and Description of the New Soil Map, (3) Elevations in Florida,(4) Review of Structure and Stratigraphy of Florida, with Special Reference to the Petroleum Possibilities.

\section{AR 18 自 OUT OF PRINT}

Eighteenth Annual Report, 1925-1926; 1927, 206 p., 58 fig. Contains (1) Statistics of Mineral Production in Florida During 1925, (2) Natural Resources of Southern Florida.

\section{AR 19 맸 OUT OF PRINT}

Nineteenth Annual Report, 1926-1927; 1928, 183 p., 5 pl., 36 fig., 9 tables. Contains (1) Statistics of Mineral Production in Florida During 1926, (2) Sand and Gravel Deposits of Florida, (3) Beach Deposits of IImenite, Zircon, and Rutile in Florida, (4) New Species of Operculina and Discocyclina from the Ocala Limestone, (5) New Species of Coskinolina and Dictyoconus? from Florida.

\section{AR 20 OUT OF PRINT}

Twentieth Annual Report, 1927-1928; 1929, 294 p., 40 pl., 4 fig., 1 map. Contains (1) Statistics of Mineral Production in Florida During 1927, (2) Geology of Florida (with geologic map), (3) The Extinct Land Mammals of Florida.

\section{AR 21/22 믈 OUT OF PRINT}

Twenty-First - Twenty-Second Annual Reports, 1928-1930; 1931, 129 p., 39 fig. Contains (1) Statistics of Mineral Production in Florida During 1928-1929, (2) Need for Conservation and Protection of Our Water Supply, with Special Reference to Waters from the Ocala Limestone, (3) The Possibility of Petroleum in Florida, (4) Beaches of Florida, (5) A Palm Nut of Attalea from the Upper Eocene of Florida.

\section{AR 23/24 믈 OUT OF PRINT}

Twenty-Third - Twenty-Fourth Annual Report, 1930-1932; 1933, 227 p., fig;, 3 tables. Contains (1) Mineral Production in Florida in 1930 and 1931, (2) Northern Disjuncts in Northern Florida (3) Cypress Domes, (4) Notes on the Geology and the Occurrence of Some Diatomaceous Earth Deposits of Florida (5) Diatoms of the Florida Peat Deposits, (6) Ground Water Resources of Sarasota County, Florida. 


\section{BIENNIAL REPORTS}

Biennial Reports (BR) record the administrative workings of the Florida Geological Survey including descriptions of the budget, programs and personnel. Biennial Reports began in 1934 upon termination of the AR series. The BR series was not published from 1960 through 1986.

\section{BR 1 믐 OUT OF PRINT}

First Biennial Report To State Board of Conservation, Biennium Ending December 31, 1934, Part IV, State

Geological Survey; 1935, 25 p.

\section{BR 2 OUT OF PRINT}

Second Biennial Report To State Board of Conservation, Biennium Ending December 31, 1936, Part III, State Geological Survey; 1937, 29 p.

\section{BR 3 믈 OUT OF PRINT}

Third Biennial Report, Biennium Ending December 31, 1938; 1939, 28 p.

\section{BR 4 믈 OUT OF PRINT}

Fourth Biennial Report, Biennium Ending December 31, 1940; 1941, 30 p.

\section{BR 5 어 OF PRINT}

Fifth Biennial Report, Biennium Ending December 31, 1942; 1943, 32 p.

\section{BR 6 믈 OUT OF PRINT}

Sixth Biennial Report, Biennium Ending December 31, 1944; 194529 p.

\section{BR 7 믄 OUT OF PRINT}

Seventh Biennial Report, Biennium Ending December 31, 1946; 1947, 22 p.

\section{BR 8 OUT OF PRINT}

Eighth Biennial Report of the Florida Geological Survey, Covering Period January 1, 1947, Through December 31, 1948; 1949, $30 \mathrm{p}$.

\section{BR 9 믈 OUT OF PRINT}

Ninth Biennial Report of the Florida Geological Survey, Covering Period January 1, 1949, Through December 31 , 1950; 1951, 32 p.

\section{BR 10 OUT OF PRINT}

Tenth Biennial Report of the Florida Geological Survey, Covering Period January 1, 1951, Through December 31, 1952; 1953, $54 \mathrm{p}$.

\section{BR 11 므 OUT OF PRINT}

Eleventh Biennial Report of the Florida Geological Survey, Covering Period January 1, 1953, Through December 31, 1954; 1955, 60 p.

\section{BR 12 OUT OF PRINT}

Twelfth Biennial Report of the Florida Geological Survey, Covering Period January 1, 1955, Through December 31, 1956; 1957, 86 p.

\section{BR 13 品 OUT OF PRINT}

Thirteenth Biennial Report of the Florida Geological Survey, Covering Period January 1, 1957, Through December 31, 1958; 1959, 84 p.

\section{BR 14 量 OUT OF PRINT}

Fourteenth Biennial Report of the Florida Geological Survey, Covering Period January 1, 1959, Through December 3, 1960; 1961, 184 p. 
BR 15 OUT OF PRINT

Biennial Report 1987-1988, by P.A. Bond, 1990, 34 p.

BR 16 品 OUT OF PRINT

Biennial Report 16, 1989-1990, by P.A. Bond, 1991, 40 p.

BR 17 OUT OF PRINT

Biennial Report 17, 1991-1992, by P.A. Bond, 1993, 50 p.

BR 18 点 OUT OF PRINT

Biennial Report 18, 1993-1994, by E. Lane, 1995, 42 p.

BR 19 OUT OF PRINT

Biennial Report 19, 1995-1996, by F.R. Rupert, 1997, 43 p.

BR 20 量 OUT OF PRINT

Biennial Report 20, 1997-1998, by J. M. Lloyd, 1999, 67 p.

BR 21 OUT OF PRINT

Biennial Report 21, 1999-2000, by R.C. Green and G.H. Means, 2001, 67 p.

BR 22 OUT OF PRINT

Biennial Report 22, 2001-2002, by J. H. Balsillie, 2003, 115 p.

BR 23 OUT OF PRINT

Biennial Report 23, 2003-2004, by T. Greenhalgh, J. Ladner, and F. Rupert, 2005, 112 p.

BR 24 OUT OF PRINT

Biennial Report 24, 2005-2006, by R.W. Hoenstine, 2009, 80 p.

BR 26 OUT OF PRINT

Biennial Report 26, 2009-2010, by P.A. Bond and F.R. Rupert, 201121 p.

BR 27 哥 OUT OF PRINT

Biennial Report 27, 2011-2012, by F.R. Rupert, 201320 p.

BR 28 OUT OF PRINT

Biennial Report 28, 2013-2014, by F.R. Rupert, 2016, 25 p.

BR 29 OUT OF PRINT

Biennial Report 29, 2015-2016, by S.A. Erb, 2017, 26 p.

BR 30 OUT OF PRINT

Biennial Report 30, 2017-2018, by S.A. Erb, 2021, 22 p.

BR 31 OUT OF PRINT

Biennial Report 31, 2019-2020, by S.A. Erb, 2022, 23 p. 


\section{BULLETINS}

\section{Bulletins (B) are comprehensive reports on geologic-related studies. They generally cover a broad subject area and/or geographic location.}

B 1 OUT OF PRINT

A Preliminary Report on the Underground Water Supply of Central Florida, by E.H. Sellards, 1908, 103 p., 6 pl., 6 text fig.

\section{B 2 OUT OF PRINT}

Roads and Road Materials of Florida, by E.H. Sellards, H. Gunter and N.H. Cox, 1911, 31 p., 4 pl.

\section{B 3 品 OUT OF PRINT}

Miocene Gastropods and Scaphopods of the Choctawhatchee Formation of Florida, by W.C. Mansfield, 1930, 189 p., $21 \mathrm{pl}$.

B 4 品 OUT OF PRINT

The Foraminifera of the Choctawhatchee Formation of Florida, by J.A. Cushman, 1930, 93 p., 12 pl.

\section{B 5 品 OUT OF PRINT}

Contains: A Fossil Teleost Fish of the Snapper Family (Lutianidae) from the Lower Oligocene of Florida, by W.K. Gregory, and The Foraminifera of the Marianna Limestone of Florida, by W.S. Cole and G.M. Ponton, 1930, 61 p., 11 pl., 2 fig.

B 6 是 OUT OF PRINT

The Pliocene and Pleistocene Foraminifera of Florida, by W.S. Cole, 1931, 79 p., 3 fig., 2 tables.

\section{B 7 OUT OF PRINT}

The Pensacola Terrace and Associated Beaches and Bars of Florida, by F. Leverett, 1931, 44 p., 8 fig., 1 map.

\section{B 8 OUT OF PRINT}

Miocene Pelecypods of the Choctawhatchee Formation of Florida, by W.C. Mansfield, 1932, 240 p., 34 pl., 3 fig.

\section{B 9 맬 OUT OF PRINT}

The Foraminifera of the Upper, Middle, and Part of the Lower Miocene of Florida, by J.A. Cushman and G.M.

Ponton, 1932, 147 p., 17 pl., 2 tables, 1 map.

\section{B 10 믈 OUT PRINT}

Miocene Vertebrates from Florida, Contains: (1) Miocene Land Mammals From Florida, by G.G. Simpson, (2) New Heteromyid Rodents from the Miocene of Florida, by A.E. Wood, (3) Aphelops from the Hawthorn Formation of Florida, by E.H. Colbert, 1932, 58 p., 30 fig.

\section{B 11 믈 OUT OF PRINT}

Ground Water Investigations in Florida, by V.T. Stringfield, 1933, 33 p.

\section{B 12 OUT OF PRINT}

New Miocene Gastropods and Scaphopods FromAlaqua Creek Valley, Florida, by W.C.Mansfield, 1935, 50 p., 5 pl.

\section{B 13 OUT OF PRINT}

Ostracoda of the Arca Zone of the Choctawhatchee Miocene of Florida, by H.V. Howe,1935, 47 p., 4 pl.

\section{B 14 믈 OUT OF PRINT}

Additions to the Molluscan Fauna of the Alum Bluff Group of Florida, by J. Gardner, 1936, 82 p., 10 pl.

\section{B 15 OUT OF PRINT}

Mollusks of the Tampa and Suwannee Limestones of Florida, by W.C. Mansfield, 1937, 334 p., 21 pl.

\section{B 16 OUT OF PRINT}

Stratigraphy and Micropaleontology of Two Deep Wells in Florida, by W.S. Cole, 1938, 6 p., 12 pl., 3 fig.

\section{B 17 OUT OF PRINT}

Scenery of Florida Interpreted by a Geologist, by C.W. Cooke, 1939, 120 p., 58 fig.

\section{B 18 OUT OF PRINT}

Notes on the Upper Tertiary and Pleistocene Mollusks of Peninsular Florida, by W.C. Mansfield, 1939, 76 p., 4 pl., 2 fig., 5 tables. 


\section{B 19 믈 OUT OFINT}

Stratigraphic and Paleontologic Studies of Wells in Florida, United Brotherhood of Carpenters and Joiners of America, Power House Well No. 2, Peninsular Oil and Refining Company's J.W. Cory No. 1, With Description of a Species of Foraminifera From Another Well, by W.S. Cole, 1941, 94 p., 18 pl., 4 fig., 1 table.

\section{B 20 을 OUT OF PRINT}

Stratigraphic and Paleontologic Studies of Wells in Florida - No. 2, Suwannee Petroleum Corporation's Sholtz No. 1, Florida Oil Discovery Company's Cedar Keys No. 2, by W.S. Cole, 1942, 90 p., 16 pl., 4 fig.

\section{B 21 믈 OUT OF PRINT}

Geology of Holmes and Washington Counties, Florida, by R.O. Vernon, 1942, 90 p., 16 pl., 4 fig.

\section{B 22 믈 OUT OF PRINT}

Contributions to Florida Vertebrate Paleontology, Contains: (1) A Fossil Squirrel-Fish from the Upper Eocene of Florida, by G.M. Conrad, (2) The Rostrum of Felsinotherium ossivalense, by J.T. Gregory, 1941, 47 p., 5 pl., 3 fig.

\section{B 23 믈 OUT OF PRINT}

Florida Dunes and Scrub, Vegetation and Geology, by H. Kurz, 1942, 154 p., 25 pl., 24 fig., 3 tables.

\section{B 24 믈 OUT OF PRINT}

Florida Mineral Industry, with Summaries of Production for 1940 and 1941, by R.O. Vernon, 1943, 207 p., 40 fig., 25 tables.

\section{B 25 믈 OUT OF PRINT}

The Natural Features of Southern Florida, Especially the Vegetation and the Everglades, by J.H. Davis, Jr., 1943, 311 p., 66 fig., 5 maps, 10 tables.

\section{B 26 믐 OUT OF PRINT}

Stratigraphic and Paleontologic Studies of Wells in Florida - No. 3, City of Quincy Water Well, St. Mary's Oil Corporation, Hilliard Turpentine Company No. 1 Well, by W.S. Cole, 1944, 168 p., frontispiece, 29 pl., 5 fig.

\section{B 27 OUT OF PRINT}

Late Cenozoic Geology of Southern Florida, with a Discussion of the Ground Water, by G.G. Parker and C.W. Cooke, 1944, 119 p., 26 pl., 4 fig.

\section{B 28 OUT OF PRINT}

Stratigraphic and Paleontologic Studies of Wells in Florida - No. 4, City of Tallahassee Water Well no. 6, Dale Mabry Field Water Well "B", Ravlin-Brown V.G. Phillips No. 1 Well, by W.S. Cole, 1945, 160 p., 22 pl., 8 fig., 17 tables.

\section{B 29 OUT OF PRINT}

Geology of Florida, by C.W. Cooke, 1945, 342 p., 1 pl., 1 map, 47 fig.

\section{B 30 믐 OUT OF PRINT}

The Peat Deposits of Florida, Their Occurrence, Development, and Uses, by J.H. Davis, Jr., 1946, 250 p., frontispiece, 36 fig., 27 tables.

\section{B 31 을 OUT ORINT}

Springs of Florida, by G.E. Ferguson, C.W. Lingham, S.K. Love, and R.O. Vernon, 1947, 198 p., frontispiece, 1 map, 37 fig., 4 tables.

\section{B 31 (Revised) 믐 OUT OF PRINT}

Springs of Florida (Revised) by J.C. Rosenau, G.L. Faulkner, C.W. Hendry, Jr. and R.W. Hull, 1977, 461 p., 212 fig., 7 tables.

\section{B 32 品 OUT OF PRINT}

Elevations in Florida, by H. Gunter, 1948, 1160 p., 2 fig.

\section{B 33 믈 OUT OF PRINT}

Geology of Citrus and Levy Counties, Florida, by R.O. Vernon, 1951, 256 p., frontispiece, 2 pl. 1 map, 40 fig., 20 tables.

\section{B 34 멍 OF PRINT}

Paleontologic Studies: (1) New Tertiary Ostracode Fauna from Levy County, Florida, by H.V. Howe; (2) The Echinoid Fauna of the Inglis Member, Moodys Branch Formation, by A.G. Fischer; 1951, 112 p., 12 pl., 18 fig., 3 tables. 
B 35 OUT OF PRINT

Eocene Mollusks from Citrus and Levy Counties, Florida, by H.G. Richards and K.V.W. Palmer, 1953,96 p., 13 pl.

B 36 OUT OF PRINT

Contribution to the Study of the Miocene of the Florida Panhandle, by H.S. Puri, 1953, 345 p., 47 pl., 21 fig.,

15 tables, 1 map.

\section{B 37 믐 OUT OF PRINT}

Geology of Jackson County, Florida, by W.E. Moore, 1955, 101 p., frontispiece, 5 pl., 27 fig., 3 tables.

\section{B 38 OUT OF PRINT}

Stratigraphy and Zonation of the Ocala Group, by H.S. Puri, 1957, 248 p., 3 pl., 30 fig., 3 tables.

\section{B 39 믕 OUT PRINT}

Mining and Mineral Resources, by J.L. Calver, 1957, 132 p., 35 fig., 12 tables.

\section{B 40 OUT OF PRINT}

Stratigraphy and Paleontology of the Late Neogene Strata of the Caloosahatchee River Area of Southern Florida, by J.R. DuBar, 1958, 267 p., 4 pl., 49 fig., 10 tables.

\section{B 41 믈 OUT PRINT}

Some Geomorphic Features of Central Peninsular Florida, by W.A. White, 1958, 92 p., 3 pl., 14 fig.

\section{B 42 믈 OUT OF PRINT}

The Limestone Resources of Washington, Holmes, and Jackson Counties, Florida, by W.D. Reves, 1961, 121 p., 27 fig., 9 tables.

\section{B 43 믈 OUT OF PRINT}

Neogene Biostratigraphy of the Charlotte Harbor Area in Southwestern Florida, by J.R. DuBar, 1962, 83 p., 8 fig., 2 pl., 8 tables.

\section{B 44 믕 OUT OF PRINT}

Osteology and Paleontology of the Passerine Birds of Reddick, Florida, by J.H. Hamon, 1964, 209 p., 13 fig., 3 tables.

\section{B 45 믈 OUT OF PRINT}

The Regional Lithostratigraphic Analysis of Paleocene and Eocene Rocks of Florida, by C.S. Chen, 1965, 105 p., 44 fig., 1 table.

\section{B 46 믕 OUT OF PRINT}

Geology of Escambia and Santa Rosa Counties, Western Florida Panhandle, by O.T. Marsh, 1966, 140 p., 28 fig., 5 pl., 16 tables.

\section{B 47 믈 OUT OF PRINT}

Geology and Ground-Water Resources of Leon County, Florida, by C.W. Hendry, Jr. and C.R. Sproul, 1966, 178 p., 37 fig., 1 pl., 8 tables.

\section{B 48 믈 OUT OF PRINT}

Geology of Jefferson County, Florida, by J.W. Yon, Jr., 1966, 115 p., 2 fig., 1 pl., 9 tables.

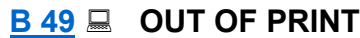

Geology of Dixie and Gilchrist Counties, Florida, by H.S. Puri, J.W. Yon, Jr., and W.R. Oglesby, 1967, 155 p., 55 fig., 2 pl., 18 tables.

\section{B 50 믈 OUT OF PRINT}

Mineral Resource Study of Holmes, Walton and Washington Counties, by J.W. Yon, Jr. and C.W. Hendry, Jr., 1969, $16 \mathrm{l}$ p., 16 fig., 11 tables.

\section{B 51 OUT OF PRINT}

The Geomorphology of the Florida Peninsula, by W.A. White, 1970, 164 p., 44 fig. 7 pl.

\section{B 52 믈 OUT OF PRINT}

Ancient Sea Level Stands in Florida, by E.C. Pirkle, W.H. Yoho, and C.W. Hendry, Jr., 1970, 61 p., 2 fig., 10 tables. 
B 53 品 OUT OF PRINT

Corals from the Chipola and Jackson Bluff Formations of Florida, by N.E. Weisbord, 1971, 100 p., 8 fig., 15 pl.

\section{B 54 OUT OF PRINT}

(1) Suwannee Limestone in Hernando and Pasco Counties, Florida, by J.W. Yon, Jr. and C.W. Hendry, Jr., 1972,42

p., 16 fig. 2 tables; (2) Petrography of the Suwannee Limestone, by A.F. Randazzo, 1972, 13 p., 7 fig., 1 table.

B 55 믈 OUT OF PRINT

Igneous and Metamorphic Basement Rocks of Florida, by C. Milton, 1972, 125 p., 85 fig., 6 tables.

B 56 品 OUT OF PRINT

$\overline{\mathrm{New}}$ and Little-Known Corals from the Tampa Formation of Florida, by N.E. Weisbord, 1973, 156 p., 35 pl.

B 57 OUT OF PRINT

Geology of Bay County, Florida, by W. Schmidt and M. Wiggs Clark, 1980, 96 p., 45 fig., 2 tables.

B 58 OUT OF PRINT

Neogene Stratigraphy and Geologic History of the Apalachicola Embayment, by W. Schmidt, 1984, 146 p., 64 fig.,

6 pl., 7 tables (Photocopy).

B 59 욜 $\$ 2.00$

The Lithostratigraphy of the Hawthorn Group (Miocene) of Florida, by T. M. Scott, 1988, 148 p., 81 fig., 1 table (Photocopy).

B 60 品 OUT OF PRINT

Geology of Wakulla County, Florida, by F. Rupert and S. Spencer, 1988, 46 p., 22 fig., 2 tables (Photocopy).

B 61 OUT OF PRINT

Geology and Ground-Water Resources of Madison County, Florida, by R. W. Hoenstine, S. M. Spencer, and T. O'Carroll, 1990, 98 p., 33 fig., 7 tables.

B 62 OUT OF PRINT

Geology of Gadsden County, Florida, by F. R. Rupert, 1990, 61 p., 30 fig., 2 tables.

B 63 믈 OUT OF PRINT

Geology of Gulf County, Florida, by F. R. Rupert, 1991, 51 p., 22 fig., 3 tables.

B 64 OUT OF PRINT

Geologic Framework of the Lower Floridan Aquifer System, Brevard County, Florida, by J.G. Duncan, W.L. Evans, III, and K.L. Taylor, 1994, 90 p., 45 fig., 5 plates.

B 65 品 OUT OF PRINT

Late Oligocene to Pliocene Evolution of the Central Portion of the South Florida Platform: Mixing of Siliciclastic and Carbonate sediments, by T. M. Missimer, 2002, 184 p., 67 fig., 12 tables, 6 plates.

\section{B 66 品 $\$ 8.00$}

Springs of Florida, by T.M. Scott, Guy H. Means, Rebecca P. Meegan, Ryan C. Means, Sam B. Upchurch, R.E. Copeland, James Jones, Tina Roberts and Alan Willet, 2004, 377 p., 172 fig., 217 tables. Digital appendices with more spring descriptions currently available online only.

\section{B 67 品Free and online only}

Florida aquifer vulnerability assessment: contamination potential models of Florida's principal aquifer systems, by J.D. Arthur, Alan E. Baker, James R. Cichon, and Alex R. Wood, 2017, 148 p., 66 fig., 18 tables, 2 appendices, 3 plates.

\section{B 68 吕 $\$ 8.00$}

Hydrogeologic framework of the Southwest Florida Water Management District, by J.D. Arthur, C. Fischler, C. Kromhout, J.M. Clayton, G.M. Kelley, R.A. Lee, L. Li, M. O'Sullivan, R. C. Green, and C.L. Werner, 2008,102 p., 175 p., 41 fig., 3 tables, 2 appendices, 59 plates.

\section{B 69 (Revised) 品 Free and online only}

Regional and statewide trends in Florida's spring and well groundwater quality (1991-2003) [revised], by

R. E. Copeland, Neal A. Doran, Aaron J. White, and Sam B. Upchurch, 2011, 393 p., online appendices.

\section{B 70 Gree and online only}

Changes In Groundwater Levels, Spring Discharge, and Concentrations of Saline and Rock-Matrix Indicators of the Floridan Aquifer System, Florida (1991-2011), by Rick Copeland and Andy Woeber, 2021, 277 p., 28 figs., 25 tables. 


\section{INFORMATION CIRCULARS}

Information Circulars (IC) are reports of a preliminary or interim nature, or updated reports on continuing investigations. They also provide compilations of large amounts of data.

IC 1 믈 OUT OF PRINT

Exploration for Oil and Gas in Florida, by H. Gunter, 1948, 68 p., 2 fig., 2 tables. Revised 1949, 106 p., 3 fig., 2 tables.

1949 Supplement, $\quad 1950, \quad 38$ p., 2 fig., 2 tables 1950 Supplement, $\quad 1951, \quad 25$ p., 2 fig., 1 table

1951 Supplement, 1952,11 p., 1 fig., 1 table 1952 Supplement, 1953,17 p., 1 fig., 1 table

1953 Supplement, $\quad 1954, \quad 40$ p., 2 fig., 1 table 1954 Supplement, $1955, \quad 35$ p., 2 fig., 2 tables

1955 Supplement, $1956, \quad 31$ p., 2 fig., 2 tables 1956 Supplement, $1957, \quad 16 \mathrm{p} \quad 2$ fig., 1 table

1957 Supplement, $1958, \quad 16$ p., 2 fig., 2 tables 1958 Supplement, $1959, \quad 13 p \quad 2$ fig., 1 table

1959 Supplement, $\quad 1960, \quad 15$ p., 2 fig., 1 table 1960 Supplement, $1961, \quad 15$ p. 2 fig., 4 tables

IC 2 昌 OUT OF PRINT

Florida Kaolins and Clays, by J.L. Calver, 1949, 59 p., 2 fig., 3 tables.

IC 3 므을 OF PRINT

Ground Water in Florida, by H.H. Cooper, Jr. and V.T. Stringfield, 1950, 6 p., 5 fig.

IC 4 믈 OUT OF PRINT

The Artesian Water of the Ruskin Area of Hillsborough County, Florida, Interim Report, by H.M. Peek, 1953, 22 p., 7 fig.

IC 5 믈 OUT OF PRINT

Interim Report on the Ground-Water Resources of Seminole County, Florida, by R.C. Heath and J.T. Barraclough, 1954, 43 leaves, 11 fig., 2 tables.

IC 6 믈 OUT OF PRINT

Interim Report on the Ground-Water Resources of Manatee County, Florida, by H.M. Peek and R.B. Anders, 1955, 38 p., 10 fig.

IC 7 葛 OUT OF PRINT

Interim Report on Surface Water Resources and Quality of Waters in Lee County, Florida, by W.E. Kenner and E. Brown, 1956, 69 p., 9 fig., 3 tables.

\section{IC 8 OUT OF PRINT}

Interim Report on Ground Water Resources of the Northeastern Part of Volusia County, Florida, by G.G. Wyrick and W.P. Leutze, 1956, 68 p., 14 fig., 4 tables.

IC 9 OUT OF PRINT

Interim Report on Salt-Water Encroachment in Dade County, Florida, by H. Klein, 1957, 5 p., 12 fig.

\section{IC 10 OUT OF PRINT}

Interim Report on the Progress of an Inventory of Artesian Wells in Florida, Leading to the Enforcement of Sections 370.051-370.054, Florida Statutes, by C.W. Hendry, Jr. and J.A. Lavendar, 1957, 178 p., 27 fig., 3 tables.

\section{IC 11 믈 OUT OF PRINT}

Interim Report on the Water Resources of Brevard County, Florida, With Special Reference to the Central Area, by D.W. Brown, W.E. Kenner, and E. Brown, 1957, 109 p., 30 fig., 15 tables.

\section{IC 12 믈 OUT OF PRINT}

Ground-Water Resources of the Stuart Area, Martin County, Florida, by W.F. Lichtler, 1957, 47 p., 9 fig., 4 tables.

IC 13 믄 OUT OF PRINT

Interim Report on the Ground-Water Resources of Flagler County, Florida, by B.J. Bermes, 1958, 32 p., 11 fig., 1 table.

\section{IC 14 믈 OUT OF PRINT}

Interim Report on the Ground-Water Resources of St. Johns County, Florida, by G.R. Tarver, 1958, 35 p., 13 fig., 1 table. 
IC 15 OUT OF PRINT

Interim Report on the Ground-Water Resources of Putnam County, Florida, by G.W. Leve, 1958, 32 p., 11 fig., 1 table.

IC 16 点 OUT OF PRINT

Changes in the Chloride Content of Ground Water in Pinellas County, Florida, Between 1947 and 1956, by

D.W. Brown, 1958, 11 p., 4 fig., 1 table.

IC 17 虽 OUT OF PRINT

Flood of June 9, 1957, at Perry, Florida, by R.H. Musgrove, 1958, 12 p., 8 fig.

\section{IC 18 品 OUT OF PRINT}

Interim Report on Geology and Ground-Water Resources of Indian River County, Florida, by B.J. Bermes, 1958,74

p., 12 fig., 4 tables.

IC 19 品 OUT OF PRINT

Record of Wells in Manatee County, Florida, by H.M. Peek, 1958, 199 p., 3 fig., 1 table.

IC 20 OUT OF PRINT

Interim Report on Surface Water Resources of Baker County, Florida, by R.W. Pride, 1958, 32 p., 7 fig., 2 tables.

\section{IC 21 OUT OF PRINT}

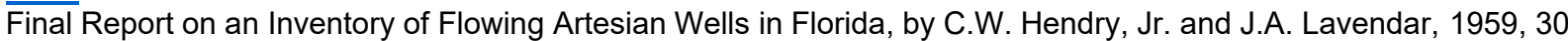
p., 9 fig., 3 tables.

\section{IC 22 OUT OF PRINT}

Record of Wells in Ruskin Area of Hillsborough County, Florida, by H.M. Peek, 1959, 85 p., 2 fig., 2 tables.

\section{IC 23 品 OUT OF PRINT}

Interim Report on the Geology and Ground-Water Resources of Northwestern Polk County, Florida, by H.G.

Stewart, Jr., 1959, 83 p., 19 fig., 9 tables.

\section{IC 24 品 OUT OF PRINT}

Record of Wells in Volusia County, Florida, by G.G. Wyrick, 1961, 96 p., 2 fig., 1 pl., 1 table.

\section{IC 25 品 OUT OF PRINT}

Surface Water Resources of Polk County, Florida, by R.C. Heath, 1961, 123 p., 50 fig., 9 tables.

\section{IC 26 OUT OF PRINT}

Interim Report on the Hydrologic Features of the Green Swamp Area in Central Florida, by R.W. Pride, F.W. Meyer, and R.N. Cherry, 1961, 96 p., 22 fig., 3 tables.

\section{IC 27 OUT OF PRINT}

Preliminary Investigation of the Ground-Water Resources of Northeast Florida, by G.W. Leve, 1961,28 p., 11 fig., 2 tables.

\section{IC 28 葛 OUT OF PRINT}

Reconnaissance of the Ground-Water Resources of the Fernandina Area, Nassau County, Florida, by G.W. Leve, 1961, 24 p., 7 fig., 2 tables.

\section{IC 29 皇 OUT OF PRINT}

Ground-Water Resources of Northwestern Collier County, Florida, by C.B. Sherwood and H. Klein, 1961,44 p., 17 fig., 2 tables.

\section{$\underline{I C} 30$ 点 OUT OF PRINT}

Interim Report on the Water Resources of Escambia and Santa Rosa Counties, Florida, by R.H. Musgrove, J.T. Barraclough, and O.T. Marsh, 1961, 89 p., 30 fig., 1 table.

\section{IC 31 OUT OF PRINT}

Stage Characteristics of Florida Lakes, by W.E. Kenner, 1961, 82 p., 62 fig.

\section{IC 32 OUT OF PRINT}

Water-Resource Records of Brevard County, Florida, by D.W. Brown, W.E. Kenner, J.W. Crooks, and J.B. Foster, 1962, 180 p., 7 fig., 16 tables.

\section{IC 33 品 OUT OF PRINT}

Water Levels in Artesian and Nonartesian Aquifers of Florida in 1960, by H.G. Healy, 1962, 19 p., 3 fig., 3 tables. 
IC 34 量 OUT OF PRINT

Ground-Water Records of Seminole County, Florida, by J.T. Barraclough, 1961, 148 p., 3 fig., 3 tables.

IC 35 品 OUT OF PRINT

Well Design as a Factor Contributing to Loss of Water from the Floridan Aquifer, Eastern Clay County, Florida, by J.B. Foster, 1962, 10 p., 4 fig.

IC 36 点 OUT OF PRINT

Interim Report on the Water Resources of Alachua, Bradford, Clay and Union Counties, Florida, by W.E. Clark, R.H. Musgrove, C.G. Menke, and J.W. Cagle, Jr., 1962, 92 p., 46 fig., 6 tables.

IC 37 嵒 OUT OF PRINT

Ground-Water Records of Flagler, Putnam, and St. Johns Counties, Florida, by B.J. Bermes, G.W. Leve, and G.R. Tarver, 1963, 89 p., 5 fig., 3 tables.

\section{IC 38 品 OUT OF PRINT}

Records of Wells and Other Water-Resources Data in Polk County, Florida, by H.G. Stewart, Jr., 1963,144 p., 4 fig., 9 tables.

\section{IC 39 OUT OF PRINT}

Surface-Water Resources of St. Johns, Flagler, and Putnam Counties, Florida, by W.E. Kenner and J.W. Crooks, 1963, 44 p., 10 fig., 16 tables.

\section{IC 40 OUT OF PRINT}

Maps Showing Depths of Selected Lakes in Florida, by W.E. Kenner, 1964, 82 p., 76 fig., 2 tables.

\section{IC 41 品 OUT OF PRINT}

Interim Report on the Water Resources of Orange County, Florida, by W.F. Lichtler, W. Anderson and B.F. Joyner, 1964, 50 p., 13 fig., 6 tables.

\section{IC 42 呢 OUT OF PRINT}

Summary of Florida Petroleum Production and Exploration in 1962, by C. Babcock, 1964, 29 p., 4 fig., 5 tables.

\section{IC 43 品 OUT OF PRINT}

Water-Resources Data for Alachua, Bradford, Clay, and Union Counties, Florida, by W.E. Clark, R.H. Musgrove, C.G. Menke, and J.W. Cagle, Jr., 1964, 154 p., 4 fig., 8 tables.

\section{IC 44 品 OUT OF PRINT}

Water-Resources Records of Hillsborough County, Florida, by C.G. Menke, E.W. Meridith, and W.S. Wetterhall, 1964, 95 p., 4 fig., 13 tables.

\section{IC 45 品 OUT OF PRINT}

Summary of Florida Petroleum Production and Exploration in 1963, by C. Babcock, 1964, 63 p., 4 fig., 12 tables, 3 pl.

\section{IC 46 OUT OF PRINT}

Ceramic Clay Investigations in Alachua, Clay, and Putnam Counties, Florida, by R.C. Hickman and H.P. Hamlin, 1964, 46 p., 4 fig.

\section{IC 47 ㅁT OF PRINT}

Control of Lake Levels in Orange County, Florida, by W. Anderson, W.F. Lichtler, and B.F. Joyner, 1965,15 p., 7 fig.

\section{IC 48 品 OUT OF PRINT}

Water Levels in Artesian and Nonartesian Aquifers in Florida, 1961-62, by H.G. Healy, 1966, 72 p., 45 fig., 1 table.

\section{IC 49 品 OUT OF PRINT}

Florida Petroleum Exploration, Production and Prospects, 1964, by C. Babcock, 1966, 117 p., 12 fig., 11 tables.

\section{IC 50 品 OUT OF PRINT}

Water Resources Records of Escambia and Santa Rosa Counties, Florida, by R.H. Musgrove, J.T. Barraclough, and R.G. Grantham, 1966, 106 p., 4 fig., 8 tables.

\section{IC 51 品 OUT OF PRINT}

Ground Water in the Immokalee Area, Collier County, Florida, by H.J. McCoy, 1967, 31 p., 11 fig., 1 table.

\section{IC 52 品 OUT OF PRINT}

Water Levels in Artesian and Nonartesian Aquifers of Florida, 1963-64, by H.G. Healy, 1968, 68 p., 46 fig., 1 table. 
IC 53 말 OUT PRINT

Ground-Water Resources Data of Charlotte, DeSoto, and Hardee Counties, Florida, by M.I. Kaufman and N.P. Dion, 1968, 24 p., 4 fig., 4 tables.

IC 54 OUT OF PRINT

Oil and Gas Activities in Florida, 1965, by C. Babcock, 1968, 50 p., 2 fig., 2 tables.

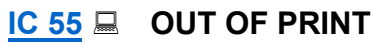

Oil and Gas Activities in Florida, 1966, by C. Babcock, 1968, 35 p., 3 fig., 2 tables.

\section{IC 56 虽 OUT OF PRINT}

Test Well Exploration in the Myakka River Basin Area, Florida, by H. Sutcliffe, Jr. and B.F. Joyner, 1968,61 p., 15 fig., 3 tables.

IC 57 OUT OF PRINT

Water Resource Records of the Econfina Creek Basin Area, Florida, by R.H. Musgrove, J.B. Foster, and L.G. Toler, 1968, 127 p., 9 fig., 14 tables.

\section{IC 58 OUT OF PRINT}

Production and Utilization of Water in the Metropolitan Area of Jacksonville, Florida, by G.W. Leve and D.A. Goolsby, 1969, 37 p., 9 fig., 14 tables.

\section{IC 59 品 OUT OF PRINT}

Seepage Tests in L-D1 Borrow Canal at Lake Okeechobee, Florida, by F.W. Meyer and J.E. Hull, 1969,31 p., 13 fig., 1 table.

\section{IC 60 品 OUT OF PRINT}

Geology of the Upper Cretaceous Clastic Section Northern Peninsular Florida, by C. Babcock, 1969,44 p., 20 fig.

\section{IC 61 品 OUT OF PRINT}

Water Levels in Artesian and Nonartesian Aquifers of Florida, 1965-66, by H.G. Healy, 1970, 55 p., 47 fig., 1 table.

\section{IC 62 OUT OF PRINT}

A Test of Flushing Procedures to Control Salt-Water Intrusion at the W.P. Franklin Dam near Ft. Myers, Florida, 15 p., 8 fig., 3 tables; and The Magnitude and Extent of Salt-Water Contamination in the Caloosahatchee River Between LaBelle and Olga, Florida, by D.H. Boggess, 1970, p. 17-39, 8 fig., 2 tables.

\section{IC 63 品 OUT OF PRINT}

Oil and Gas Activities in Florida, 1967, by C. Babcock, 1970, 32 p., 7 fig., 3 tables.

\section{IC 64 虽 OUT OF PRINT}

Report on Geophysical and Television Explorations in City of Jacksonville Water Wells, by G.W. Leve, 1970,15 p., 9 fig.

\section{IC 65 OUT OF PRINT}

Oil and Gas Activities in Florida, 1968, by C. Babcock, 1970, 40 p., 10 fig., 7 tables.

\section{IC 66 品 OUT OF PRINT}

Mineral Producers in Florida, 1968, by E.L. Maxwell, 1970, 40 p., 4 fig.

\section{IC 67 맵 OUT OFINT}

Selected Water Resource Records for Okaloosa County and Adjacent Areas, by J.B. Foster and C.A. Pascale, 1971, 95 p., 4 fig., 9 tables.

\section{IC 68 品 OUT OF PRINT}

Water Levels in Artesian and Nonartesian Aquifers of Florida, 1967-68, by H.G. Healy, 1970, 78 p., 51 fig., 1 table.

\section{IC 69 品 OUT OF PRINT $\mathbf{h}$}

Selected Flow Characteristics of Florida Streams and Canals, Summaries of Flow Duration and of Low and High Flows at Gaging Stations, by R.C. Heath and E.T. Wimberly, 1971, 595 p., 7 fig.

\section{IC 70 品 OUT OF PRINT}

The Beneficial Uses of Zones of High Transmissivities in the Florida Subsurface for Water Storage and Waste Disposal, by R.O. Vernon, 1970, 39 p., 15 fig., 1 table. 
IC 71 OUT OF PRINT

Oil and Gas Activities in Florida, 1969, by C. Babcock, 1971, 48 p., 7 fig., 7 tables.

IC 72 OUT OF PRINT

Land Use Conflicts and Phosphate Mining in Florida, by J.W. Sweeney, 1971, 41 p., 6 fig., 2 tables.

IC 73 品 OUT OF PRINT

Water Levels in Artesian and Nonartesian Aquifers of Florida, 1969-70, by H.G. Healy, 1972, 73 p., 54 fig., 1 table.

\section{IC 74 曷 OUT OF PRINT}

Construction of Waste-Injection Monitor Wells Near Pensacola, Florida, by J.B. Foster and D.A. Goolsby, 1972,34 p., 16 fig., 7 tables.

\section{IC 75 品 OUT OF PRINT}

Saline-Water Intrusion From Deep Artesian Sources in the McGregor Isles Area of Lee County, Florida, by

C.R. Sproul, D.H. Boggess, and H.J. Woodard, 1972, 30 p., 9 fig., 3 tables.

\section{IC 76 맬 OUT OF PRINT}

Hydrologic Aspects of Freshening Upper Old Tampa Bay, Florida, by J.A. Mann, 1972, 39 p., 15 fig., 2 tables.

\section{IC 77 品 OUT OF PRINT}

Ground Water in the Hallandale Area, Florida, by H.W. Bearden, 1972, 32 p., 13 fig., 5 tables.

\section{IC 78 曷 OUT OF PRINT}

Records of Hydrologic Data, Walton County, Florida, by C.A. Pascale, C.F. Essig, Jr., and R.R. Herring, 1972,103 p., 5 fig., 9 tables.

\section{IC 79 品 OUT OF PRINT}

Flood of September 20-23, 1969, in the Gadsden County Area, Florida, by W.C. Bridges and D.R. Davis, 1972,37 p., 23 fig., 3 tables.

\section{IC 80 吕 OUT OF PRINT}

Oil and Gas Activities in Florida, 1970, by C. Babcock, 1972, 82 p., 6 fig., 13 tables.

\section{IC 81 品 OUT OF PRINT}

Public Water Supplies of Selected Municipalities in Florida, 1970, by H.G. Healy, 1972, 213 p., 28 fig., 4 tables.

\section{IC 82 OUT OF PRINT}

Flow and Chemical Characteristics of the St. Johns River at Jacksonville, Florida, by W. Anderson and D.A. Goolsby, 1973, 33 fig.

\section{IC 83 물 OF PRINT}

Estimated Use of Water in Florida, 1970, by R.W. Pride, 1973, 31 p., 6 fig., 10 tables.

\section{IC 84 品 OUT OF PRINT}

The Mineral Industry of Florida, 1971, by W.F. Stowasser, 1973, 12 p., 1 fig., 11 tables.

\section{IC 85 品 OUT OF PRINT}

Water Levels in Artesian and Nonartesian Aquifers of Florida, 1971-72, by H.G. Healy, 1974, 94 p., 54 fig., 1 table.

\section{IC 86 品 OUT OF PRINT}

Hydrogeologic Characteristics of the Surficial Aquifer in Northwest Hillsborough County, Florida, by W.C. Sinclair, 1974, 98 p., 1 fig., 4 tables.

\section{IC 87 品 FREE}

List of Publications. (Revised periodically). Available at no charge. Most recent revision available on web site.

\section{IC 88 品 OUT OF PRINT}

The Mineral Industry of Florida, 1972, by W.F. Stowasser and W.R. Oglesby, 1974, 13 p., 10 tables.

\section{IC 89 品 OUT OF PRINT}

The Mineral Industry of Florida, 1973, by W.F. Stowasser and C.W. Hendry, Jr., 1976, 13 p., 9 tables.

\section{IC 90 品 OUT OF PRINT}

The Mineral Industry of Florida, 1974, by J.W. Sweeney and C.W. Hendry, Jr., 1977, 14 p., 11 tables. 
IC 91 OUT OF PRINT

The Mineral Industry of Florida, 1975, by J.W. Sweeney and C.W. Hendry, Jr., 1979, 16 p., 11 tables.

IC 92 点 OUT OF PRINT

The Mineral Industry of Florida, 1976, by J.W. Sweeney and C.W. Hendry, Jr., 1979, 14 p., 7 tables.

\section{IC 93 品 OUT OF PRINT}

Earthquakes and Seismic History of Florida, by E. Lane, 1983, 8 p., 5 fig., 1 table. (Updated by Open File Report 40).

\section{IC 94 品 OUT OF PRINT}

The Mineral Industry of Florida, 1977, 1978, 1979, by J.R. Boyle and C.W. Hendry, Jr., 1981, 10 p., 7 tables.

\section{IC 95 品 OUT OF PRINT}

The Mineral Industry of Florida, 1980, by J.R. Boyle and C.W. Hendry, Jr., 1982, 11 p., 7 tables.

\section{IC 96 品 OUT OF PRINT}

The Mineral Industry of Florida, 1981, by J.R. Boyle and C.W. Hendry, Jr., 1983, 11 p., 6 tables.

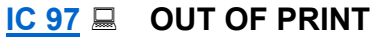

The Mineral Industry of Florida, 1982, by J.R. Boyle and C.W. Hendry, Jr., 1984, 11 p., 6 tables.

\section{IC 98 品 OUT OF PRINT}

Annotated Bibliography of Florida Basement Geology and Related Regional and Tectonic Studies, Including an Appendix of Florida Deep Well Data, by J.M. Lloyd, 1985, 72 p.

\section{IC 99 点 OUT OF PRINT}

The Mineral Industry of Florida, 1983-, published by U.S. Bureau of Mines and U.S. Geological Survey.

See: http://minerals.usgs.gov/minerals/pubs/state/fl.html.

\section{IC 100 OUT OF PRINT}

Palynology and Paleoecology of a Lignitic Peat from Trail Ridge, Florida, by F.J. Rich, 1985, 15 p., 4 fig., 1 pl.

\section{IC 101 OUT OF PRINT}

Summary of Florida Petroleum Production and Exploration Onshore and Offshore, Through 1984, by A.V. Applegate and J.M. Lloyd, 1985, 69 p., 16 fig., 2 pl.

\section{IC 102 品 OUT OF PRINT}

The Industrial Minerals of Florida, by K.M. Campbell, 1986, 94 p., 18 fig., 1 table.

\section{IC 103 䓛 OUT OF PRINT}

Shallow Stratigraphic Core Tests on File at the Florida Geological Survey, compiled by R.A. Johnson, 1986,431 p., 1 fig. (Includes a copy of Map Series 111).

\section{IC 104 回 OUT OF PRINT}

(1) 1985 Florida Petroleum Production and Exploration, by J.M. Lloyd and A.V. Applegate; (2) The Brown Dolomite Zone of the Lehigh Acres Formation (Aptian) in the South Florida Basin - A Potentially Prolific Producing Horizon Offshore, by A.V. Applegate, 1987, 66 p., 15 fig., 1 table, 5 appendices.

\section{IC 105 OUT OF PRINT}

(1) The Industrial Minerals Industry Directory of Florida, by S.M. Spencer; (2) Geology, Mining and Reclamation at the Radar Hill Quarry, Citrus County, Florida, by J.W. Yon, W.R. Waite, and C.T. Williams, 1989, 51 p., 10 figures.

\section{IC 106 OUT OF PRINT}

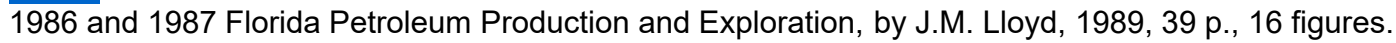

\section{IC 107 OUT OF PRINT}

(1) 1988 and 1989 Florida Petroleum Production and Exploration, by J.M. Lloyd, Including Florida Petroleum Reserve Estimates, by C.H. Tootle; (2) Petroleum Exploration and Development Policies in Florida: Response to Public Concern for Sensitive Environments, by J.M. Lloyd and J.M. Ragland; (3) Petrology and Provenance of the Norphlet Formation, Panhandle, Florida, by G.W. Scott, 1991, 121 p.

IC 108 OUT OF PRINT

1990 and 1991 Florida Petroleum Production and Exploration, by J.M Lloyd, Including Florida Petroleum Reserve Estimates, by C.H. Tootle, 1992, 31 p., 12 figures. 


\section{IC 109 OUT OF PRINT}

Industrial Minerals Industry Directory of Florida, by S.M. Spencer, 1993, 30 p., 1 fig., 2 tables, 1 plate. (Includes a copy of Map Series 139).

IC 110 OUT OF PRINT

1992 and 1993 Florida Petroleum Production and Exploration, by J.M. Lloyd, Including Florida Petroleum

Reserve Estimates, by C.H. Tootle, 1994, 30 p., 12 fig., 10 tables.

IC 111 鸮 OUT OF PRINT

1994 and 1995 Florida Petroleum Production and Exploration, by J.M. Lloyd, 1997, 62 p.

IC 112 OUT OF PRINT

Industrial Minerals Industry Directory of Florida, by S.M. Spencer, 1999, 26 p. 


\section{LEAFLETS}

Leaflets (L) are short publications related to areas of general, educational, or public interest.

\section{1 OUT OF PRINT}

Your Water Resources: Storage, Origin, Needs, Uses, Movement, Conservation, prepared by Florida Geological Survey, 1960, 24 p., 22 fig.

\section{1 (Revised) 믕 OUT OF PRINT}

Your Water Resources: Origin, Quality, Needs, Uses, Quantity, Movement, Occurrence, Conservation, prepared by Florida Geological Survey, Revised 1963, 35 p., 23 fig.

\section{2 OUT OF PRINT}

Water for Thirsty Industry - It's Your Problem, prepared by Florida Geological Survey, 9 p., 7 fig.

\section{3 뭉 OUT OF PRINT}

The Pensacola Area's Water, prepared by Florida Geological Survey, 1965, 13 p., 16 fig.

\section{3 (Revised) 吕 OUT OF PRINT}

Water in the Pensacola, Florida, Area, Revised 1979. U.S. Geological Survey Water-Resources Investigations Report 79-89.

\section{4 品 OUT OF PRINT}

Chronological Bibliography of Principal Published Ground-Water Reports in Florida Prepared by the U.S.

Geological Survey or the Florida Geological Survey, 1908-1963, by L.W. Hyde, 1964, 18 p., 5 fig.

\section{$\underline{5}$ OUT OF PRINT}

Water Control vs. Sea-Water Intrusion, Broward County, Florida, by C.B. Sherwood and R.G. Grantham, 1965, 13 p., 9 fig.

\section{5 (2nd ed.) 品 OUT OF PRINT}

Water Control vs. Sea-Water Intrusion, Broward County, Florida, by C.B. Sherwood and R.G. Grantham, Second Edition, 1966, 15 p., 13 fig.

\section{6 믈 OUT OF PRINT}

Jacksonville's Water, by G.W. Leve, 1965, 12 p., 3 fig., 2 tables.

\section{$\underline{4} 7$ OUT OF PRINT}

Salt Intrusion Can Be Controlled, by H. Klein, 1965, 6 p., 3 fig.

\section{8 믈 OUT OF PRINT}

Water in Orange County, Florida, by B.F. Joyner, W.F. Lichtler, and W. Anderson, 1968, 17 p., 12 fig.

\section{9 OUT OF PRINT}

Large Springs of Florida's "Sun Coast": Citrus and Hernando Counties, by J.A. Mann and R.N. Cherry, 1969, 23 p., 15 fig., 1 table.

\section{10 믈 OUT OF PRINT}

Florida Caverns State Park, a Nature-Made Geologic Wonderland, by W. Schmidt, 1982, 16 p., 8 fig.

\section{11 OUT OF PRINT}

The Geology of Torreya State Park, by K.M. Campbell and R.W. Hoenstine, 1982, 8 p.

\section{12 믈 OUT OF PRINT}

A Geologic Guide to the Suwannee River, Ichetucknee Springs, O'leno and Manatee Springs State Parks, by R.W. Hoenstine and S. Weissinger, 1982, 28 p.

\section{$\underline{\underline{A G}} \underline{\mathrm{B}}$ OUT OF PRINT}

A Geologic Guide to the State Parks of the Florida Panhandle Coast: St. George Island, St. Joseph Peninsula, St. Andrews and Grayton Beach Parks and Recreation Areas, by K.M. Campbell, 1984, 23 p.

\section{14 믈 OUT OF PRINT}

Geology of the State Parks in the Florida Keys, by E. Lane, 1986, 28 p., 21 fig. 
L 15 OUT OF PRINT

The Florida Geological Survey: Geological Research Contributing to Responsible Growth in Florida, by E. Lane, 1991, 6 p., 7 fig.

\section{16 OUT OF PRINT}

The Geology of Falling Waters State Recreation Area, by F.R. Rupert and E. Lane, 1992, 10 p., 8 fig.

\section{17 OUT OF PRINT}

This is the Florida Geological Survey, by F.R. Rupert, 2004, trifold, color.

\section{18 OUT OF PRINT}

Timeline of Highlights and Significant Historical Events in the Evolution of the Florida Geological Survey, by F.R. Rupert, 2007, trifold, color.

\section{19 员 FREE}

Florida's Rocks and Minerals, compiled and updated by J.M. Lloyd, P.A. Bond, and S.E. Ramdeen, 2009, trifold, monochrome, 2 p. Updated 2022.

\section{20 易FREE}

A Homeowner's Guide to Sinkholes in Florida, by L. Hannon and C. Kromhout, 2023, 11 p. 


\section{MAP SERIES}

Map Series (MS) contain geologic and other related data interpretations presented in graphic formats including maps, cross sections, and graphs, and generally include accompanying text.

\section{MS 1 品 OUT OF PRINT}

Piezometric Surface of the Floridan Aquifer in Florida: July 6-17, 1961, by H.G. Healy, 1962. Size: 15 x 15 inches. Scale: approx. 30 miles to 1 inch.

\section{MS 2 邑 OUT OF PRINT}

Maps Showing Mined-Out Areas and Ownership, in Parts of Polk and Hillsborough Counties, Land-Pebble Phosphate District, Florida, by J.B. Cathcart and E.L.M. Ward, 1953. In two sheets, each 22 x 17 inches. Scale: approx. 1 mile to 1 inch.

\section{MS 3 品 OUT OF PRINT}

Surface Occurrences of Geologic Formations in Florida, After Cooke, 1945, with revisions by Vernon, 1951. Size:

$10 \times 14$ inches. Scale: approx. 48 miles to 1 inch.

\section{MS 3 (Revised) 点 OUT OF PRINT}

Surface Occurrences of Geologic Formations in Florida, After Cooke, 1945, with revisions by Vernon and Puri, 1959. Size: 10 x 14 inches. Scale: approx. 48 miles to 1 inch.

\section{MS 4 OUT OF PRINT}

Piezometric Surface and Areas of Artesian Flow of the Floridan Aquifer in Florida, July 6-17, 1961, by G. Healy, 1962. Size: $17.5 \times 22$ inches. Scale: approx. 30 miles to 1 inch.

\section{MS 4 (2nd ed.) 믕 OUT OF PRINT}

Piezometric Surface and Areas of Artesian Flow of the Floridan Aquifer in Florida, July 6-17, 1961, by G. Healy, Second edition, 1975. Size: 17.5 × 22 inches. Scale: approx. 30 miles to 1 inch.

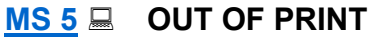

Hydrologic Features of the Floridan Aquifer in Seminole County, Florida, prepared by N.D. Hoy and J.R. Teel, 1963. Size: $19 \times 25$ inches. Scale: approx. 2 miles to 1 inch.

\section{MS 6 品 FREE}

An online interactive petroleum well location map of the entire state.

An historical set of the 26 map sheets listed below showing petroleum well locations is available for download at: http://publicfiles.dep.state.fl.us/FGS/FGS Publications/MS/MS6 complete.pdf

Regional Maps:
1. Pensacola
2. Tallahassee
3. Valdosta
4. Jacksonville
5. Apalachicola
6. Gainesville
7. Daytona Beach
8. Plant City
9. Orlando
10. Tampa
11. Fort Pierce
12. West Palm Beach
13. Miami
14. Key West

\section{Regional Maps:}

MS 7 品 OUT OF PRINT

Generalized Water-Table Contours in Southern Florida, prepared by N.D. Hoy, 1964. Size: 10 x 15 inches. Scale: approx. 25 miles to 1 inch.

\section{MS 8 OUT OF PRINT}

Mineral Resources and Industries of Florida, 1956, by J.L. Calver. Size 9 x 12-1/2 inches. Scale: approx. 50 miles to 1 inch.

\section{Field Maps:}

15. Jay, Mt. Carmel

16. Blackjack Creek

17. Lehigh Park, Lake Trafford, Corkscrew

18. West Sunoco Felda, Mid Felda

19. Sunniland,Sunoco Felda, Townsend Canal

20. Seminole

21. Bear Island, Pepper Hammock

22. 40 Mile Bend

23. Sweetwater Creek, McClellan

24. Baxter Island

25. Raccoon Point

26. Bluff Springs 


\section{MS 9 OUT OF PRINT}

Quality of Water from the Floridan Aquifer in Hillsborough County, Florida, 1963, by D.E. Shattles, 1965. Size: $19 \times 25$ inches. Scale: approx. 4 miles to 1 inch.

\section{MS 10 OUT OF PRINT}

Quality of Water from the Floridan Aquifer in the Econfina Creek Basin Area, Florida, 1962, by L.G. Toler and W.J. Shampine, 1965. Size: $19 \times 25$ inches. Scale: approx. 3 miles to 1 inch.

\section{MS 11 品 OUT OF PRINT}

Fluoride Content of Water from the Floridan Aquifer of Northwest Florida, 1963, by L.G. Toler, 1965. Size: $19 \times 25$ inches. Scale: 15 miles to 1 inch.

\section{MS 12 品 OUT OF PRINT}

Chloride Concentration in Water from the Upper Part of the Floridan Aquifer in Florida, by W.J. Shampine, 1965. Size: $17.5 \times 22$ inches. Scale: 30 miles to 1 inch.

\section{MS 12 (Revised) 品 OUT OF PRINT}

Chloride Concentration in Water from the Upper Part of the Floridan Aquifer in Florida, by W.J. Shampine, 1965, Revised 1975. Size: 17.5 x 22 inches. Scale: approx. 30 miles to 1 inch.

\section{MS 13 品 OUT OF PRINT}

Hardness of Water from the Upper Part of the Floridan Aquifer in Florida, by W.J. Shampine, 1965. Size: $17.5 \times 22$ inches. Scale: approx. 30 miles to 1 inch.

\section{MS 13 (Revised) 品 OUT OF PRINT}

Hardness of Water from the Upper Part of the Floridan Aquifer in Florida, by W.J. Shampine, 1965, Revised 1975. Size: $17.5 \times 22$ inches. Scale: approx. 30 miles to 1 inch.

\section{MS 14 品 OUT OF PRINT}

Dissolved Solids in Water from the Upper Part of the Floridan Aquifer in Florida, by W.J. Shampine, 1965. Size: $x 22$ inches. Scale: approx. 30 miles to 1 inch.

\section{MS 14 (Revised) 맬 OUT OF PRINT}

Dissolved Solids in Water from the Upper Part of the Floridan Aquifer in Florida, by W.J. Shampine, 1965, Revised 1975. Size: 17.5 x 22 inches. Scale: approx. 30 miles to 1 inch.

\section{MS 15 駡 OUT OF PRINT}

Sulfate Concentration in Water from the Upper Part of the Floridan Aquifer in Florida, by W.J. Shampine, 1965. Size: x 22 inches. Scale: approx. 30 miles to 1 inch.

\section{MS 15 (Revised) 매을 OUT OF PRINT}

Sulfate Concentration in Water from the Upper Part of the Floridan Aquifer in Florida, by W.J. Shampine, 1965, Revised 1975. Size: $17.5 \times 22$ inches. Scale: approx. 30 miles to 1 inch.

\section{MS 16 OUT OF PRINT}

Principal Aquifers in Florida, by L.W. Hyde, 1965. Size: 17.5 x 22 inches. Scale: approx. 30 miles to 1 inch.

\section{MS 16 (Revised) 品 OUT OF PRINT}

Principal Aquifers in Florida, by L.W. Hyde, 1965, Revised 1975. Size: 17.5 x 22 inches. Scale: approx. 30 miles to 1 inch.

\section{MS 17 OUT OF PRINT}

Quality of Water from the Floridan Aquifer in Brevard County, Florida, 1963, by W.J. Shampine, 1965. Size: $19 \times 25$ inches. Scale: approx. 10 miles to 1 inch.

\section{MS 18 OUT OF PRINT}

Geologic Map of Florida. Compiled by R.O. Vernon and H.S. Puri, 1964. Size: 19 x 25 inches. Scale: approx. 30 miles to 1 inch $(1: 1,900,800)$.

\section{MS 19 OUT OF PRINT}

Folio of South Florida Basin, A Preliminary Study, by W.R. Oglesby, 1965. Size: 9 x 14 inches. Scale: approx. 40 miles to 1 inch.

\section{MS 20 OUT OF PRINT}

Chloride Content of Ground Water in Pinellas County, Florida, in 1950 and 1963, by R.N. Cherry, 1966. Size: $20.5 \times 27$ inches. Scale: approx. 4-1/2 miles to 1 inch. 
MS 21, OUT OF PRINT

Availability of Ground Water in Orange County, Florida, by W.F. Lichtler and B.F. Joyner, 1966. Size: 27-3/4 x 36-3/4 inches. Scale: approx. 2 miles to 1 inch.

MS 22 OUT OF PRINT

Runoff in Florida, by W.E. Kenner, 1966. Size: 16 x 20 inches. Scale: approx. 30 miles to 1 inch.

MS 23 品 OUT OF PRINT

Fluoride Content of Water from the Floridan Aquifer in Northwestern Florida, by L.G. Toler, 1966 . Size: $16-3 / 4 \times 24$ inches. Scale: approx. 15 miles to 1 inch.

\section{MS 24 묘은 OUT OFINT}

Availability and Quality of Surface Water in Orange County, Florida, by W. Anderson and B.F. Joyner, 1966. Size: 22-3/4 x 34-1/2 inches. Scale: approx. 3 miles to 1 inch.

\section{MS 25 OUT OF PRINT}

Temperature and Chemical Characteristics of the St. John's River Near Cocoa, Florida, by K.A. MacKichan, 1967. Size: 25 x 18-3/4 inches, 12 fig.

\section{MS 26 OUT OF PRINT}

Ground-Water Features in Escambia and Santa Rosa Counties, Florida, by J.T. Barraclough, 1967. Size: 24 x 38 inches. Scale: approx. 10 miles to 1 inch.

\section{MS 27 OUT OF PRINT}

Chemical Character of Water in the Floridan Aquifer in Southern Peace River Basin, Florida, by M.I. Kaufman and N.P. Dion, 1967. Size: 26 × 31 inches. Scale: approx. 10 miles to 1 inch.

\section{MS 28 OUT OF PRINT}

Drainage Basins in Florida, by W.E. Kenner, R.W. Pride, and C.S. Conover, 1967. Size: 19 x 25 inches. Scale: approx. 30 miles to 1 inch.

\section{MS 29 OUT OF PRINT}

Water in Broward County, Florida, by H.J. McCoy, and C.B. Sherwood, 1968. Size: 25 x 38 inches. Scale: approx. 3-1/2 miles to 1 inch.

\section{MS 30 OUT OF PRINT}

Surface Drainage Characteristics in Volusia County, Florida, by D.D. Knochenmus, 1968. Size: 25.5 x 32 inches. Scale: approx. 6 miles to 1 inch.

\section{MS 31 品 OUT OF PRINT}

Seasonal Variation of Streamflow in Florida, by W.E. Kenner, 1969. Size: 17.5 x 22 inches. Scale: approx. 30 miles to 1 inch.

\section{MS 31 (Updated) 曷 OUT OF PRINT}

Seasonal Variation of Streamflow in Florida, by W.E. Kenner, 1969, Updated 1975. Size: 17.5 x 22 inches. Scale: approx. 30 miles to 1 inch.

\section{MS 32 OUT OF PRINT}

The Difference Between Rainfall and Potential Evaporation in Florida, by F.N. Visher and G.H. Hughes, 1969. Size: $17.5 \times 22$ inches. Scale: approx. 30 miles to 1 inch.

\section{MS 32 (2nd ed.) 믈 OUT OF PRINT}

The Difference Between Rainfall and Potential Evaporation in Florida, by F.N. Visher and G.H. Hughes, Second edition, 1975. Size: $17.5 \times 22$ inches. Scale: approx. 30 miles to 1 inch.

\section{MS 33 OUT OF PRINT}

Generalized Distribution and Concentration of Orthophosphate in Florida Streams, by M.I. Kaufman, 1969. Size: $17.5 \times 22$ inches. Scale: approx. 30 miles to 1 inch.

\section{MS 33 (Revised) 品 OUT OF PRINT}

Generalized Distribution and Concentration of Orthophosphate in Florida Streams, by M.I. Kaufman, 1969, Revised 1975. Size: $17.5 \times 22$ inches. Scale: approx. 30 miles to 1 inch.

\section{MS 34 OUT OF PRINT}

Average Flow of Major Streams in Florida, by W.E. Kenner, E.R. Hampton, and C.S. Conover, 1969. Size: $17.5 \times 22$ inches. Scale: approx. 30 miles to 1 inch. 
MS 34 (Updated) 묘 OUT OF PRINT

Average Flow of Major Streams in Florida, by W.E. Kenner, R. Hampton, and C.S. Conover, 1969, Updated 1975.

Size: 17.5 x 22 inches. Scale: approx. 30 miles to 1 inch.

\section{MS 35 몽 OUT OF PRINT}

Color of Water in Florida Streams and Canals, by M.I. Kaufman, 1969. Size: 17.5 x 22 inches. Scale: approx. 30 miles to 1 inch

\section{MS 35 (Revised) $\square \quad$ OUT OF PRINT}

Color of Water in Florida Streams and Canals, by M.I. Kaufman, 1969, Revised 1975. Size: 17.5 x 22 inches. Scale: approx. 30 miles to 1 inch.

\section{MS 36 믈 OUT PRINT}

Estimated Water Use in Florida, 1965, by R.W. Pride, 1970. Size: 17.5 x 22 inches. Scale: approx. 30 miles to 1 inch.

\section{MS 36 (2nd ed.) $\square \quad$ OUT OF PRINT}

Estimated Water Use in Florida, 1965, by R.W. Pride, Second Edition, 1975. Size: 17.5 x 22 inches. Scale: approx. 30 miles to 1 inch.

\section{MS 37 믐 OUT OF PRINT}

The $\mathrm{pH}$ of Water in Florida Streams and Canals, by M.I. Kaufman, 1970. Size: 17.5 x 22 inches. Scale: approx. 30 miles to 1 inch.

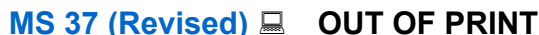

The pH of Water in Florida Streams and Canals, by M.I. Kaufman, 1970, Revised 1975. Size: 17.5 x 22 inches. Scale: approx. 30 miles to 1 inch.

\section{MS 38 므을 OF PRINT}

Hydrologic Setting of Deer Point Lake Near Panama City, Florida, by G.H. Hughes, 1970. Size: 34 x 23 inches. Scale: approx. $3 / 8$ mile to 1 inch.

\section{MS 39 믈 OUT ORINT}

Hydrologic Factors Affecting the Utilization of Land for Sanitary Landfills in Northern Hillsborough County, Florida, by J.W. Stewart and R.V. Hanan, 1970. Size: 34 × 24 inches. Scale: approx. 2 miles to 1 inch.

\section{MS 40 믈 OUT OF PRINT}

Annual and Seasonal Rainfall in Florida, by G.H. Hughes, E.R. Hampton, and D.F. Tucker, 1971. Size: 18 x 22 inches. Scale: approx. 100 miles to 1 inch.

\section{MS 41 몽 OUT OF PRINT}

Bouguer Anomaly Map of South Florida, by W.R. Oglesby and M.M. Ball, 1971. Size: 23 x 26 inches. Scale: approx. 8 miles to 1 inch.

\section{MS 42 묘 OUT OF PRINT}

Depth to Base of Potable Water in the Floridan Aquifer, by H. Klein, 1971. Size: 17.5 x 22 inches. Scale: approx. 30 miles to 1 inch.

\section{MS 42 (Revised) 믕 OUT OF PRINT}

Depth to Base of Potable Water in the Floridan Aquifer, by H. Klein, 1971, Revised 1975. Size: 17.5 x 22 inches. Scale: approx. 30 miles to 1 inch.

\section{MS 43 믐 OUT OF PRINT}

Temperature of Florida Streams, by W. Anderson, 1971. Size: 17.5 x 22 inches. Scale: approx. 30 miles to 1 inch.

\section{MS 43 (Revised) 品 OUT OF PRINT}

Temperature of Florida Streams, by W. Anderson, 1971, Revised 1975. Size: 17.5 x 22 inches. Scale: approx. 30 miles to 1 inch.

\section{MS 44 OUT OF PRINT}

Ground Water in Lake County, Florida, by D.D. Knochenmus, 1971. Size: 36 x 23 inches, 5 fig.

\section{MS 45 믐 OUT OF PRINT}

Streamflow Variation and Distribution in the Big Cypress Watershed During Wet and Dry Periods, by H.J. Freiberger, 1972. Size: $28 \times 23$ inches. Scale: approx. 7.5 miles to 1 inch. 
MS 46 品 OUT OF PRINT

Guide to Users of Ground Water in Bay County, Florida, by J.B. Foster, 1972, Size: 34.5 x 23 inches. Scale: approx.

7 miles to 1 inch.

\section{MS 47 OUT OF PRINT}

Sea-Water Intrusion in the Upper Part of the Floridan Aquifer in Coastal Pasco County, Florida, 1969, by

R.C. Reichenbaugh, 1972. Size: 36 × 22.5 inches. Scale: approx. 2 miles to 1 inch.

\section{MS 48 OUT OF PRINT}

A Hydrologic Description of Lake Thonotosassa Near Tampa, Florida, by R.C. Reichenbaugh and J.D. Hunn, 1972. Size: 36 x 22.5 inches. Scale: approx. 625 feet to 1 inch.

\section{MS 49 量 OUT OF PRINT}

A Hydrologic Description of Lake Magdalene Near Tampa, Florida, by J.D. Hunn and R.C. Reichenbaugh, 1971. Size: $36 \times 22$ inches. Scale: approx. 500 feet to 1 inch.

\section{MS 50 OUT OF PRINT}

Land Use in the Big Cypress Area, Southern Florida, by J.T. Armbruster, 1972. Size: 28 x 22.5 inches. Scale: approx. 4 miles to 1 inch.

\section{MS 51 OUT OF PRINT}

The Chemical Type of Water in Florida Streams, by M.I. Kaufman, 1972. Size: 17.5 x 28 inches. Scale: approx. 30 miles to 1 inch.

\section{MS 51 (Revised) 品 OUT OF PRINT}

The Chemical Type of Water in Florida Streams, by M.I. Kaufman, 1972, Revised 1975. Size: 17.5 x 28 inches. Scale: approx. 30 miles to 1 inch.

\section{MS 52 怘 OUT OF PRINT}

Bouguer Anomaly Map of Northwest Florida and Adjacent Shelf, by S. Chaki and W.R. Oglesby, n.d. Size: $23 \times 32$ inches.

\section{MS 53 OUT OF PRINT}

The Shallow Aquifer of Southwest Florida, by H. Klein, 1972. Size: 23 x 28 inches. Scale: approx. miles to 1 inch.

\section{MS 54 司 OUT OF PRINT}

A Hydrologic Description of Lake Minnehaha at Clermont, Florida, by P.W. Bush, n.d. Size: 23 x 36 inches. Scale: approx. 1200 feet to 1 inch.

\section{MS 55 品 OUT OF PRINT}

Quantity and Quality of Surface Water in Marion County, Florida, by W. Anderson and G.L. Faulkner, 1973. Size: $24 \times 36$ inches. Scale: approx. 4 miles to 1 inch.

\section{MS 56 OUT OF PRINT}

Top of the Floridan Artesian Aquifer, by R.O. Vernon, 1973. Size: 21.5 x 18.5 inches. Scale: approx. 50 miles to inches.

\section{MS 57 OUT OF PRINT}

Bouguer Anomaly Map of the Florida Peninsula and Adjoining Continental Shelves, by W.R. Oglesby, M.M. Ball, and S.J. Chaki, n.d. Size: 24 x 36 inches. Scale: approx. 16 miles to 1 inch.

\section{MS 58 OUT OF PRINT}

Specific Conductance of Water in Florida Streams and Canals, by L.J. Slack and M.I. Kaufman, 1973. Size: $17.5 \times 22$ inches. Scale: approx. 30 miles to 1 inch.

\section{MS 58 (Revised) 물 OUT OF PRINT}

Specific Conductance of Water in Florida Streams and Canals, by L.J. Slack and M.I. Kaufman, 1973 , Revised 1975. Size: $17.5 \times 22$ inches. Scale: approx. 30 miles to 1 inch.

\section{MS 59 OUT OF PRINT}

Encroaching Salt Water in Northeast Palm Beach County, Florida, by H.G. Rodis, 1973. Size: 24 x 35 inches. Scale varies.

\section{MS 60 OUT OF PRINT}

Hydrology of Lake Tarpon Near Tarpon Springs, Florida, by J.D. Hunn, 1974. Size: 24 x 37 inches. Scale: approx. 1400 feet to 1 inch. 


\section{MS 61 OUT OF PRINT}

The Anclote and Pithlachascotee Rivers as Water Supply Sources, by R.W. Coble, 1973. Size: 24 x 37 inches.

Scales: approx. 4 miles to 1 inch and 2.5 miles to 1 inch.

\section{MS 62 믄 OUT OF PRINT}

Water-Level Fluctuations of Lakes in Florida, by G.H. Hughes, 1974. Size: 17.5 x 22 inches. Scale: approx. 30 miles to 1 inch.

\section{MS 63 믄 OUT OF PRINT}

An Index to Springs of Florida, by J.C. Rosenau and G.L. Faulkner, 1974. Size: 17.5 x 22 inches. Scale: approx. 30 miles to 1 inch.

\section{MS 63 (Revised) 물 OUT OF PRINT}

An Index to Springs of Florida, by J.C. Rosenau and G.L. Faulkner, 1974, Revised 1975. Size: 17.5 x 22 inches. Scale: approx. 30 miles to 1 inch.

\section{MS 64 品 OUT OF PRINT}

Low Streamflow in Florida - Magnitude and Frequency, by R.B. Stone, 1974. Size: 17.5 x 22 inches. Scale: approx. 30 miles to 1 inch.

\section{MS 65 品 OUT OF PRINT}

The Observation-Well Network of the U.S. Geological Survey in Florida, by H.G. Healy, 1974. Size: 17.5 x 22 inches. Scale: approx. 30 miles to 1 inch.

\section{MS 66 品 OUT OF PRINT}

Surface Water Features of Florida, by L.J. Snell and W.E. Kenner, 1974. Size: 17.5 x 22 inches. Scale: approx. 30 miles to 1 inch.

\section{MS 67 OUT OF PRINT}

Ground-Water Withdrawals in the Upper Peace and Upper Alafia River Basins, Florida, by A.F. Robertson and L.R. Mills, 1974. Size: 25 x 29.5 inches. Scale: approx. 7 miles to 1 inch.

\section{MS 68 OUT OF PRINT}

Recharge Areas of the Floridan Aquifer in Seminole County and Vicinity, Florida, by C.H. Tibbals, 1975 . Size: 24 x 29 inches. Scale: approx. 1 mile to 1 inch.

\section{MS 69 OUT OF PRINT}

Hydrology of the Oklawaha Lakes Area of Florida, by P.W. Bush, 1974. Size: 24 x 37 inches. Scale: approx. 4 miles to 1 inch.

\section{MS 70 品 OUT OF PRINT}

Estimated Yield of Fresh-Water Wells in Florida, by C.A. Pascale, 1975. Size: 17.5 x 22 inches. Scale: approx. 30 miles to 1 inch.

\section{MS 71 品 OUT OF PRINT}

Terraces and Shorelines of Florida, by H.G. Healy, 1975. Size: 17 x 21 inches. Scale: approx. 30 miles to 1 inch.

\section{MS 72 OUT OF PRINT}

River Basin and Hydrologic Unit Map of Florida, by C.S. Conover and S.D. Leach, 1975. Size: 17.5 x 22 inches. Scale: approx. 30 miles to 1 inch.

\section{MS 73 回 OUT OF PRINT}

Potentiometric Surface and Areas of Artesian Flow of the Floridan Aquifer in Florida, May 1974, by H.G. Healy, 1975. Size: $17.5 \times 22$ inches. Scale: approx. 30 miles to 1 inch.

\section{MS 74 OUT OF PRINT}

Thickness of the Potable Water Zone in the Floridan Aquifer, by L.V. Causey and G.W. Leve, 1976. Size: $17.5 \times 22$ inches. Scale: approx. 30 miles to 1 inch.

\section{MS 75 OUT OF PRINT}

Nitrogen Loads and Concentrations in Florida Streams, by L.J. Slack and D.A. Goolsby, 1976. Size: 17.5 x 22 inches. Scale: approx. 30 miles to 1 inch.

\section{MS 76 OUT OF PRINT}

Program for Monitoring Surface-Water Quality in Florida, by L.J. Slack, 1977. Size: 20 x 24 inches. Scale: approx. 30 miles to 1 inch. 
MS 77 DUT OF PRINT

Dissolved-Solids Concentrations and Loads in Florida Surface Waters, by J.E. Dysart and D.A. Goolsby, 1977. Size: $17 \times 19$ inches. Scale: 30 miles to 1 inch.

\section{MS 78 OUT OF PRINT}

Environmental Geology Series - Pensacola Sheet, by W. Schmidt, 1978. Size: 17 x 22 inches. Scale: 1:250,000.

MS 79 몸 OUT OF PRINT

Environmental Geology Series - Gainesville Sheet, by M.S. Knapp, 1978. Size: 22 x 36 inches. Scale: 1:250,000.

\section{MS 80 OUT OF PRINT}

Environmental Geology Series - Ft. Pierce Sheet, by E. Lane, M.S. Knapp, and T. Scott, 1980. Size: 22 × 36 inches. Scale: $1: 250,000$.

\section{MS 81 OUT OF PRINT}

Runoff from Hydrologic Units in Florida, by G.H. Hughes. Size: $17.5 \times 22$ inches. Scale: 30 miles to 1 inch.

MS 82 믈 OUT OF PRINT

Chemical Quality of Water Used for Municipal Supply in Florida, 1975, by G.G. Phelps, 1978. Size: 17.5 x 22 inches.

Scale: 30 miles to 1 inch.

\section{MS 83 品 OUT OF PRINT}

Principal Uses of Freshwater in Florida, 1975, by G.G. Phelps, 1978. Size: 17.5 x 22 inches. Scale: 30 miles to 1 inch.

\section{MS 84 DUT OF PRINT}

Environmental Geology Series - Apalachicola Sheet, by W. Schmidt, 1978. Size: 22 x 36 inches. Scale: 1:250,000.

MS 85 믈 OUT OF PRINT

Environmental Geology Series - Orlando Sheet, by T.M. Scott, 1978. Size: 22 x 36 inches. Scale: 1:250,000.

\section{MS 86 OUT OF PRINT}

Top of the Floridan Aquifer of Northwest Florida, by T. Kwader and W. Schmidt, 1978. Size: 22 x 36 inches. Scale: $1: 250,000$.

\section{MS 87 OUT OF PRINT}

Freshwater Use in Florida, 1975, by S.D. Leach, 1978. Size: $22 \times 17.5$ inches. Scale: 30 miles to 1 inch.

\section{MS 88 品 OUT OF PRINT}

Environmental Geology Series - Valdosta Sheet, by M.S. Knapp, 1978. Size: 22 x 36 inches. Scale: 1:250,000.

\section{MS 89 믄 OUT OF PRINT}

Environmental Geology Series - Jacksonville Sheet, by T.M. Scott, 1978. Size: 22 x 36 inches. Scale: 1:250,000.

\section{MS 90 믐 OUT OF PRINT}

Environmental Geology Series - Tallahassee Sheet, by W. Schmidt, 1979. Size: 22 x 36 inches. Scale: 1:250,000.

\section{MS 91 믕 OUT OF PRINT}

Quality of Untreated Water for Public Supplies in Florida with Reference to the National Primary Drinking Water Regulations, by R.W. Hull and G.A. Irwin, 1979. Size: 27 x 22 inches. Scale: 100 miles to 1 inch.

\section{MS 92 믐 OUT OF PRINT}

Top of the Floridan Aquifer of North Central Florida, by M.S. Knapp, 1979. Size: 35 x 23 inches. Scale: 1:500,000.

\section{MS 93 OUT OF PRINT}

Environmental Geology Series - Daytona Beach Sheet, by T.M. Scott, 1979. Size: 21 x 33 inches. Scale: 1:250,000.

\section{MS 94 믈 OUT OF PRINT}

Potential Subsurface Zones for Liquid-Waste Storage in Florida, by J.A. Miller, 1979. Size: 22 x 18 inches. Scale: 50 miles to 1.5 inch.

\section{MS 95 믈 OUT OF PRINT}

Top of the Floridan Aquifer in the St. Johns River Water Management District, by T.M. Scott and M. Hajishafie, 1980. Size: 22 × 36 inches. Scale: 8 miles to 1 inch. 
MS 96 OUT OF PRINT

Water Quality of Florida Springs, by L.J. Slack and J.C. Rosenau, 1979. Size: 34 x 17.5 inches. Scale: 50 miles to inch.

\section{MS 97 OUT OF PRINT}

Environmental Geology Series - Tampa Sheet, by M.S. Knapp, 1980. Size: 22 x 36 inches. Scale: 1:250,000.

\section{MS 98 OUT OF PRINT}

Areas of Natural Recharge to the Floridan Aquifer in Florida, by J.W. Stewart, 1980. Size: $22 \times 17.5$ inches. Scale: 30 miles to 1 inch.

\section{MS 99 OUT OF PRINT}

Environmental Geology Series - Tarpon Springs Sheet, by R. Deuerling, 1981. Size: 22 x 36 inches. Scale: 1:250,000.

\section{MS 100 OUT OF PRINT}

Environmental Geology Series - West Palm Beach Sheet, by Lane, 1980. Size: 22 x 36 inches. Scale: 1:250,000.

\section{MS 101 매를 OU PRINT}

Environmental Geology Series - Miami Sheet, by E. Lane, 1981. Size: 22 x 36 inches. Scale: 1:250,000.

\section{MS 102 品 OUT OF PRINT}

Estimated Pumpage from Ground-Water Sources for Public Supply and Rural Domestic Use in Florida, 1977, by H.G. Healy, 1981. Size: 22 x 17 inches. Scale: 30 miles to 1 inch.

\section{MS 103 㗊 OUT OF PRINT}

Estimated Water Use in Florida, 1980, by S.D. Leach, 1982. Size: 22 x 17 inches. Scale: 30 miles to 1 inch.

\section{MS 104 매묘 OUT OF PRINT}

Potentiometric Surface of the Floridan Aquifer in Florida, May 1980, by H.G. Healy, 1982. Size: 22 x 17 inches. Scale: 30 miles to 1 inch.

\section{MS 105 맬 OUT OF PRINT}

Consumptive Use of Freshwater in Florida, 1980, by S.D. Leach, 1982. Size: 22 x 17 inches. Scale: 30 miles to 1 inch.

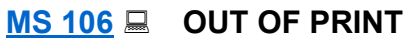

Estimated Irrigation Water Use in Florida, 1980, by R.M. Spechler, 1983. Size: $22 \times 17$ inches. Scale: 30 miles to 1 inch.

\section{MS 107 品 OUT OF PRINT}

Long-Term Streamflow Stations in Florida, 1980, by D.W. Foose and J.E. Sohm, 1983. Size: 22 x 17 inches. Scale: 30 miles to 1 inch.

\section{MS 108 맬 OUT OF PRINT}

Projected Public Supply and Rural (Self-Supplied) Water Use in Florida Through Year 2020, by S.D. Leach, 1984. Size: 22 x 17 inches. Scale: 30 miles to 1 inch.

\section{MS 109 品 OUT OF PRINT}

Wetlands in Florida, by P.S. Hampson, 1984. Size: 22 × 17 inches. Scale: 30 miles to 1 inch.

\section{MS 110 虽 OUT OF PRINT}

Sinkhole Type, Development, and Distribution in Florida, by W.C. Sinclair and J.W. Stewart, 1985. Size: 22 x 17 inches. Scale: 30 miles to 1 inch.

\section{MS 111 品 OUT OF PRINT}

Index Map of Shallow Stratigraphic Core Tests on File at the Florida Geological Survey, compiled by R.A. Johnson, 1986. Size: 22 x 17 inches. Scale: approx. 31 miles to 1 inch. (Included with IC 103).

\section{MS 112 물 OUT OF PRINT}

Geology and Waste Disposal in Florida, by P. Bond, 1987. Size: 30 x 40 inches. Scale: 50 mi to 15/16 inch.

\section{MS 113 品 OUT OF PRINT}

Mineral Resources of Sumter County, Florida, by J.W. Yon, R.W. Hoenstine, and S.M. Spencer, 1988. Size: 29 x 19.5 inches. Scale: 2 miles to 1 inch. 
MS 114 무은 OUT OF PRINT

Mineral Resources of Hernando County, Florida, by J.W. Yon, R.W. Hoenstine, and S.M. Spencer, 1988. Size:

$19.5 \times 29$ inches. Scale: 2 miles to 1 inch.

\section{MS 115 뭉 OUT OF PRINT}

Mineral Resources of Citrus County, Florida, by J.W. Yon, R.W. Hoenstine, and S.M. Spencer, 1988. Size: 19.5 × 29

inches. Scale: 2 miles to 1 inch.

\section{MS 116 믄 OUT OF PRINT}

Mineral Resources of Levy County, Florida, by E. Lane, R.W. Hoenstine, J.W. Yon, and S.M. Spencer, 1988. Size:

$27.5 \times 30$ inches. Scale: 2 miles to 1 inch.

\section{MS 117 믈 OUT OF PRINT}

Mineral Resources of Marion County, Florida, by R.W. Hoenstine, E. Lane, F. Rupert, J.W. Yon, and S.M. Spencer, 1988. Size: 27 x 34 inches. Scale: 2 miles to 1 inch.

\section{MS 118 OUT OF PRINT}

Long-Term Stage Records of Lakes in Florida, 1987, by D.W. Foose, 1987. Size: $18 \times 21$ inches. Scale: 30 miles to 1 inch.

\section{MS 119 믈 OUT OF PRINT}

Potentiometric Surface of the Upper Floridan Aquifer in Florida, May 1985, by G.L. Barr, 1987. Size: 18 x 21 inches. Scale: 30 miles to 1 inch.

\section{MS 120 OUT OF PRINT}

Mineral Resources of Collier County, by J.W. Yon, S.M. Spencer, R.W. Hoenstine, and E. Lane, 1988. Size: 30 x 34 inches. Scale: 2 miles to 1 inch.

\section{MS 121 OUT OF PRINT}

Mineral Resources of Madison County, Florida, by S.M. Spencer, J.W. Yon, R.W. Hoenstine, and E. Lane, 1988. Size: $19.5 \times 29$ inches. Scale: 2 miles to 1 inch

\section{MS 122 문 OU PRINT}

Runoff to Streams in Florida, by R.P. Rumenik, 1988. Size: 21 x 18 inches. Scale: 30 miles to 1 inch.

\section{MS 123 OUT OF PRINT}

Freshwater Withdrawals and Water-Use Trends in Florida, 1985, by R.L. Marella, 1989. Scale: 30 miles to 1 inch.

\section{MS 124 OUT OF PRINT}

Ground-Water Sources and 1985 Withdrawals in Florida, by S. Conover, J. Vecchioli, and D.W. Foose, 1989. Scale: 30 miles to 1 inch.

\section{MS 125 虽 $\$ 2.00$}

A Guide Map to Geologic and Paleontologic Sites in Florida, by F.R. Rupert, 1989. Scale: approx. 20 miles to 1 inch.

\section{MS 126 뭉 OUT OF PRINT}

Mineral Resources of St. Johns County, Florida, by R.W. Hoenstine, P. Bond, S.M. Spencer, and J.W. Yon, 1989.

Scale: 2 miles to 1 inch.

\section{MS 127 D OUT OF PRINT}

Mineral Resources of Flagler County, Florida by E. Lane, P. Bond, R.W. Hoenstine, S.M. Spencer, and J.W. Yon, 1989. Scale: 2 miles to 1 inch.

\section{MS 128 OUT OF PRINT}

Mineral Resources of Putnam County, Florida, by S.M. Spencer, R.W. Hoenstine, E. Lane, and J.W. Yon, 1989.

Scale: 2 miles to 1 inch.

\section{MS 129 品 OUT OF PRINT}

Mineral Resources of Jefferson County, Florida, by P. Bond, R.W. Hoenstine, and E. Lane, 1989. Scale: 2 miles to 1 inch.

\section{MS 130 OUT OF PRINT}

Mineral Resources of Lee County, Florida, by E. Lane, T. Scott, R.W. Hoenstine, and J.W. Yon, 1990. Scale: 2 miles to 1 inch. 
MS 131 OUT OF PRINT

Mineral Resources of Alachua County, Florida, by R.W. Hoenstine, J.W. Yon, E. Lane, and S.M. Spencer, 1990.

Scale: 2 miles to 1 inch.

\section{MS 132 OUT OF PRINT}

Transmissivity and Well Yields of the Upper Floridan Aquifer in Florida, by W.J. Andrews, 1990. Scale: 30 miles to 1 inch.

\section{MS 133 品 OUT OF PRINT}

Mineral Resources of Clay County, Florida, by S.M. Spencer, J.W. Yon, R.W. Hoenstine, and E. Lane, 1991. Scale:

2 miles to 1 inch.

\section{MS 134 品 OUT OF PRINT}

Mineral Resources of Union and Bradford Counties, Florida, by E. Lane, R.W. Hoenstine, F.R. Rupert, and S.M. Spencer, 1991. Scale: 2 miles to 1 inch.

\section{MS 135 믈 OUT OF PRINT}

Mineral Resources of Hamilton County Florida, by S.M. Spencer, F. Rupert, R.W. Hoenstine, and E. Lane, 1993.

Scale: 2 miles to 1 inch.

\section{MS 136 OUT OF PRINT}

Mineral Resources of Columbia County Florida, by E. Lane, R.W. Hoenstine, and S.M. Spencer, 1993. Scale: 2 miles to 1 inch.

\section{MS 137 葛 OUT OF PRINT}

Mineral Resources of Suwannee County, Florida, by R.W. Hoenstine, S.M. Spencer, and E. Lane, 1993. Scale:

2 miles to 1 inch.

\section{MS 138 品 OUT OF PRINT}

Potentiometric Surface of the Upper Floridan Aquifer in Florida, May 1990, by G.L. Barr, 1992. Scale: 30 miles to 1 inch.

\section{MS 139 品 OUT OF PRINT}

Industrial Mineral Operations in Florida, by S.M. Spencer, 1993. (Included with IC-109). Scale: 25 miles to 1 inch.

\section{MS 140 品 OUT OF PRINT}

Potentiometric Surface of the Upper Floridan Aquifer in Florida, May and June, 1995, by G.L. Mahon, A.A. Sepulveda, and A.F. Choquette, 1997. Scale: 1:2,027,520.

\section{MS 141 品 OUT OF PRINT}

Freshwater Withdrawals and Water-Use Trends in Florida, 1990, by R.L. Marella, 1997. Scale: 1:2,027,520.

\section{MS 142 品 OUT OF PRINT}

Low Flow of Florida Streams, by A.F. Choquette, R.P. Rumenik, and J.W. Grubbs, 1997. Scale: 1:2,027,520.

\section{MS 143 매료 OUT PRINT}

Irrigated Crop Acreage and Water Withdrawals in Florida, 1990, by R.L. Marella, 1997. Scale: 1:2,027,520.

\section{MS 144 品 OUT OF PRINT}

Land Uses in the Ecosystem Management Areas of Florida, by A.A. Sepulveda, 1999. Scale approx. 1:2,027,520

\section{MS 145 品 OUT OF PRINT}

Freshwater Withdrawals and Water-Use Trends in Florida, 1995, by R. L. Marella, 2000. Scale: 1:2,027,520.

\section{MS 146 品 $\$ 7.50^{* *}$}

Geologic Map of the State of Florida (large), by T.M. Scott, K.M. Campbell, F.R. Rupert, J.D. Arthur, R.C Green, G.H. Means, T.M. Missimer, J.M. Lloyd, J.W. Yon, J.G. Duncan, 2001. Scale: 1:750,000.

${ }^{* *}$ Includes OFR 80, Text to Accompany the Geologic Map of the State of Florida.

\section{MS 147 品 OUT OF PRINT}

Geologic Map of the State of Florida (small), by T.M. Scott, 2000 (simplified version of MS 146). Scale: approx. $1: 4,224,000$.

\section{MS 149 品 OUT OF PRINT}

Potentiometric Surface of the Upper Floridan Aquifer in Florida, May 2000, by R.L. Marella and A.A. Sepulveda, 2004, Scale: approx. 1:2,027,520. 
MS 150 䓛 $\$ 2.00$

State of Florida Geological Highway Map and Geoscience Resource Guide, by Jon Arthur, Paulette Bond, Harley Means, Frank Rupert, and Tom Scott. GIS graphics by David Anderson and Clint Kromhout. Includes 57 sites of geologic interest plus a bibliography of selected field trip guidebooks. 2007; scale varies. Comes folded 9" x 4" and opens to flat size of $39 "$ x 27 " (2 sided).

\section{MS 151 몽 $\quad$ Free and online only}

Potentiometric Surface of the Upper Floridan Aquifer September 2012, by James R. Cichon, 2017. One color map sheet, $36.07 \times 38.33$ inches, scale 1:900,000.

\section{MS 152 Free and online only}

Potentiometric Surface of the Upper Floridan Aquifer May 2013, by James R. Cichon, 2018. One color map sheet, 36 x 38 inches, scale 1:900,000.

\section{MS 153 믈 Free and online only}

Potentiometric Surface of the Upper Floridan Aquifer May 2014, by James R. Cichon, 2018. One color map sheet, 36 x 38 inches, scale 1:900,000.

\section{MS 154 Free and online only}

Potentiometric Surface of the Upper Floridan Aquifer May 2015, by James R. Cichon, 2018. One color map sheet, 36 × 38 inches, scale 1:900,000.

\section{MS 155 Free and online only}

Potentiometric Surface of the Upper Floridan Aquifer September 2013, by James R. Cichon, 2018. One color map sheet, 36 x 38 inches, scale 1:900,000.

\section{MS 156 믈}

Potentiometric Surface of the Upper Floridan Aquifer September 2014, by James R. Cichon, 2018. One color map sheet, 36 × 38 inches, scale 1:900,000.

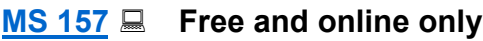

Potentiometric Surface of the Upper Floridan Aquifer September 2015, by James R. Cichon, 2018. One color map sheet, 36 × 38 inches, scale 1:900,000.

\section{MS 158 Free and online only}

Potentiometric Surface of the Upper Floridan Aquifer May 2018, by Casey K. Albritton, 2021. One color map sheet, 36 × 38 inches, scale 1:900,000.

\section{MS 159 品Free and online only}

Potentiometric Surface of the Upper Floridan Aquifer September 2018, by Casey K. Albritton, 2022. One color map sheet, 36 × 38 inches, scale 1:900,000.

\section{MS 160 Free and online only}

Potentiometric Surface of the Upper Floridan Aquifer May 2019, by Gary D. Fowler III and Casey K. Albritton, 2022. One color map sheet, 36 × 38 inches, scale 1:900,000.

\section{MS 161 Free and online only}

Potentiometric Surface of the Upper Floridan Aquifer September 2019, by Gary D. Fowler III and Casey K. Albritton, 2022. One color map sheet, 36 x 38 inches, scale 1:900,000.

\section{MS 162 Free and online only}

Potentiometric Surface of the Upper Floridan Aquifer May 2020, by Gary D. Fowler III and Mary E. Lupo, 2023. One color map sheet, 36 × 38 inches, scale 1:900,000. 


\section{OPEN FILE MAP SERIES}

Open File Map Series (OFMS) present interpreted geologic and related information and provide for rapid reporting of ongoing investigations and interim data. These maps are printed on demand, at $\$ 2.00$ apiece (does not include shipping tube). The price for certain maps is different where marked.

OFMS 1 물

Mines and Quarries Greater than 10 Acres in Size in the Suwannee River Water Management District, 1992, by

M. Macesich, N. Martinez, M. Groszos, F. Rupert, and R. White. Scale: 1:250,000.

OFMS 2 品

An Isopach Map of the Hawthorn Group in the Suwannee River Water Management District, 1992, by M. Groszos and F. Rupert. Scale: 1:250,000.

OFMS 3

Geologic Map of Nassau County, Florida, by T. Scott, 1992. Scale: 1:126,720.

OFMS 4 맬

Geologic Map of Duval County, Florida, by T. Scott, 1992. Scale: 1:126,720.

OFMS 5

Geologic Map of Clay County, Florida, by T. Scott, 1992. Scale: 1:126,720.

OFMS 6 品

Geologic Map of Putnam County, Florida, by T. Scott, 1992. Scale: 1:126,720.

OFMS 7

Geologic Map of Flagler County, Florida, by T. Scott, 1992. Scale: 1:126,720.

OFMS 8

Geologic Map of Volusia County, Florida, by T. Scott, 1992. Scale: 1:126,720.

OFMS 9

Geologic Map of Lake County, Florida, by T. Scott, 1992. Scale: 1:126,720.

OFMS 10

Geologic Map of Citrus County, Florida, by K. Campbell and T. Scott, 1992. Scale: 1:126,720.

OFMS 11

Geologic Map of Levy County, Florida, by K. Campbell, 1992. Scale: 1:126,720.

OFMS 12 맬

Geologic Map of Alachua County, Florida, by T. Scott and K. Campbell, 1992. Scale: 1:126,720.

OFMS 13 品

Geologic Map of Marion County, Florida, by T. Scott, 1992. Scale: 1:126,720.

OFMS 14

Geologic Map of Escambia County, Florida, by T. Scott, 1993. Scale: 1:126,720.

OFMS 15 曋

Geologic Map of Santa Rosa County, Florida, by T. Scott, 1993. Scale: 1:126,720.

OFMS 16

Geologic Map of Okaloosa County, Florida, by T. Scott, 1993. Scale: 1:126,720.

OFMS 17

Geologic Map of Walton County, Florida, by T. Scott, 1993. Scale: 1:126,720.

OFMS 18

Geologic Map of Washington County, Florida, by K. Campbell, 1993. Scale: 1:126,720. 
OFMS 19 品

Geologic Map of Bay County, Florida, by K. Campbell, 1993. Scale: 1:126,720.

OFMS 20 薦

Geologic Map of Calhoun County, Florida, by K. Campbell, 1993. Scale: 1:126,720.

OFMS 21 맬

Geologic Map of Franklin County, Florida, by F. Rupert, 1993. Scale: 1:126,720.

OFMS 22 品

Geologic Map of Gadsden County, Florida, by T. Scott, 1993. Scale: 1:126,720.

OFMS 23 品

Geologic Map of Gulf County, Florida, by F. Rupert, 1993. Scale: 1:126,720.

OFMS 24 品

Geologic Map of Holmes County, Florida, by K. Campbell, 1993. Scale: 1:126,720.

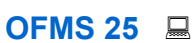

Geologic Map of Jackson County, Florida, by T. Scott, 1993. Scale: 1:126,720.

OFMS 26 品

Geologic Map of Liberty County, Florida, by F. Rupert, 1993. Scale: 1:126,720.

OFMS 27 맬

Geologic Map of Madison County, Florida, by K. Campbell, 1993. Scale: 1:126,720.

OFMS 28 呢

Geologic Map of Leon County, Florida, by T. Scott, 1993. Scale: 1:126,720.

OFMS 29 맬

Geologic Map of Taylor County, Florida, by K. Campbell, 1993. Scale: 1:126,720.

OFMS 30 맬

Geologic Map of Wakulla County, Florida, by F. Rupert, 1993. Scale: 1:126,720.

OFMS 31 물

Geologic Map of Jefferson County, Florida, by F. Rupert and J.W. Yon, 1993. Scale: 1:126,720.

OFMS 32 물

Geologic Map of Hamilton County, Florida, by T. Scott, 1993. Scale: 1:126,720.

OFMS 33 品

Geologic Map of Suwannee County, Florida, by F . Rupert, J. Lloyd, and K. Campbell, 1993. Scale: 1:126,720.

OFMS 34 물

Geologic Map of Lafayette County, Florida, by K. Campbell, 1993. Scale: 1:126,720.

OFMS 35 品

Geologic Map of Dixie County, Florida, by K. Campbell, 1993. Scale: 1:126,720.

OFMS 36 吕

Geologic Map of Gilchrist County, Florida, by F. Rupert and K. Campbell, 1993. Scale: 1:126,720.

OFMS 37 맸

Geologic Map of Columbia County, Florida, by T. Scott, 1993. Scale: 1:126,720.

OFMS 38 品

Geologic Map of Baker County, Florida, by T. Scott, 1993. Scale: 1:126,720.

OFMS 39 물

Geologic Map of Union and Bradford County, Florida, by T. Scott, 1993. Scale: 1:126,720.

OFMS 40 品

Geologic Map of Sumter County, Florida, by K. Campbell, 1993. Scale: 1:126,720.

OFMS 41 曷

Geologic Map of Hernando County, Florida, by K. Campbell, 1993. Scale: 1:126,720. 
OFMS 42 品

Geologic Map of Pasco County, Florida, by J. Arthur, 1993. Scale: 1:126,720.

OFMS 43 品

Geologic Map of Seminole County, Florida, by T. Scott, 1993. Scale: 1:126,720.

OFMS 44 品

Geologic Map of Pinellas County, Florida, by J. Arthur and K. Campbell, 1993. Scale: 1:126,720.

OFMS 45 뭉

Geologic Map of Hillsborough County, Florida, by K. Campbell and J. Arthur, 1993. Scale: 1:126,720.

OFMS 46 매

Geologic Map of Polk County, Florida, by K. Campbell, 1993. Scale: 1:126,720.

OFMS 47 品

Geologic Map of Orange County, Florida, by T. Scott, 1993. Scale: 1:126,720.

OFMS 48 品

Geologic Map of Osceola County, Florida, by T. Scott, 1993. Scale: 1:126,720.

OFMS 49 品

Geologic Map of Brevard County, Florida, by T. Scott, 1993. Scale: 1:126,720.

OFMS 50 品

Geologic Map of Manatee County, Florida, by K. Campbell, 1993. Scale: 1:126,720.

OFMS 51 물

Geologic Map of Hardee County, Florida, by T. Scott and K. Campbell, 1993. Scale: 1:126,720.

OFMS 52 맸

Geologic Map of Highlands County, Florida, by J. Arthur, 1993. Scale: 1:126,720.

OFMS 53 뭈

Geologic Map of St. Lucie County, Florida, by J. Duncan and T. Scott, 1993. Scale: 1:126,720.

OFMS 54 品

Geologic Map of Okeechobee County, Florida, by T. Scott, 1993. Scale: 1:126,720.

OFMS 55 뭈

Geologic Map of Indian River County, Florida, by T. Scott, 1993. Scale: 1:126,720.

OFMS 56 品

Geologic Map of Martin County, Florida, by J. Duncan and T. Scott, 1993. Scale: 1:126,720.

OFMS 57 맬

Geologic Map of Sarasota County, Florida, by K. Campbell and J. Arthur, 1993. Scale: 1:126,720.

OFMS 58 맬

Geologic Map of DeSoto County, Florida, by J. Arthur, 1993. Scale: 1:126,720.

OFMS 59 品

Geologic Map of Charlotte County Florida, by T. Scott and T. Missimer, 1993. Scale: 1:126,720.

OFMS 60 品

Geologic Map of Glades County, Florida, by K. Campbell, 1993. Scale: 1:126,720.

OFMS 61 맬

Geologic Map of Lee County, Florida, by T. Missimer and T. Scott, 1993. Scale: 1:126,720.

OFMS 62 品

Geologic Map of Hendry County, Florida, by T. Scott, 1993. Scale: 1:126,720.

OFMS 63 品

Geologic Map of Collier County, Florida, by J. Duncan, 1993. Scale: 1:126,720. 
OFMS 64 品

Geologic Map of Broward County, Florida, by J. Duncan, 1993. Scale: 1:126,720.

OFMS 65 品

Geologic Map of Palm Beach County, Florida, by T. Scott, 1993. Scale: 1:126,720.

OFMS 66/1 品

Sheet 1 - Geologic Map of Monroe County, Florida, by J. Duncan, 1993. This map sheet includes the mainland portion of Monroe County. Scale: 1:126,720.

OFMS $66 / 2$ 局

Sheet 2 - Geologic Map of Monroe County, Florida, by J. Duncan, 1993. This map sheet includes the Keys portion of Monroe County. Scale: 1:126,720.

OFMS 67 맸

Geologic Map of Dade County, Florida, by J. Duncan, 1993. Scale: 1:126,720.

OFMS 68 葛

Geologic Map of St. Johns County, Florida by T. Scott, 1994. Scale: 1:126,720.

OFMS 69 - OFMS 82 品 $\$ 28.00 /$ set

Generalized Prime Recharge for Aquifers of Primary Use, by K. Campbell, J. Lloyd, and T. Scott, 1993. Scale:

1:250,000. 14 map sheets, bound. Note: see individual sheets listed below. Order individual sheets or bound set.

OFMS 69

Generalized Prime Recharge for Aquifers of Primary Use: Pensacola Sheet, compiled by K. Campbell. J. Lloyd, and T. Scott, 1993. Scale: 1:250,000.

\section{OFMS 70}

Generalized Prime Recharge for Aquifers of Primary Use: Tallahassee Sheet, compiled by K. Campbell, J. Lloyd, and T. Scott, 1993. Scale: 1:250,000.

\section{OFMS 71}

Generalized Prime Recharge for Aquifers of Primary Use: Valdosta Sheet, compiled by K. Campbell, J. Lloyd, and T. Scott, 1993. Scale: 1:250,000.

\section{OFMS 72}

Generalized Prime Recharge for Aquifers of Primary Use: Jacksonville Sheet, compiled by K. Campbell, J. Lloyd, and T. Scott, 1993. Scale: 1:250,000.

\section{OFMS 73}

Generalized Prime Recharge for Aquifers of Primary Use: Apalachicola Sheet, (Note: No prime recharge to aquifers of primary use in this area), 1993. Scale: 1:250,000.

\section{OFMS 74}

Generalized Prime Recharge for Aquifers of Primary Use: Gainesville Sheet, compiled by K. Campbell, J. Lloyd, and T. Scott, 1993. Scale: 1:250,000.

\section{OFMS 75}

Generalized Prime Recharge for Aquifers of Primary Use: Daytona Beach Sheet, compiled by K. Campbell, J. Lloyd, and T. Scott, 1993. Scale: 1:250,000.

\section{OFMS 76}

Generalized Prime Recharge for Aquifers of Primary Use: Plant City Sheet, compiled by K. Campbell, J. Lloyd, and T. Scott, 1993. Scale: 1:250,000.

\section{OFMS 77}

Generalized Prime Recharge for Aquifers of Primary Use: Orlando Sheet, compiled by K. Campbell, J. Lloyd, and T. Scott, 1993. Scale: 1:250,000.

\section{OFMS 78}

Generalized Prime Recharge for Aquifers of Primary Use: Tampa Sheet, compiled by K. Campbell, J. Lloyd, and T. Scott, 1993. Scale: 1:250,000. 
OFMS 79

Generalized Prime Recharge for Aquifers of Primary Use: Fort Pierce Sheet, compiled by K. Campbell, J. Lloyd, and T. Scott, 1993. Scale: 1:250,000.

\section{OFMS 80}

Generalized Prime Recharge for Aquifers of Primary Use: West Palm Beach Sheet, compiled by K. Campbell, J. Lloyd, and T. Scott, 1993. Scale: 1:250,000.

\section{OFMS 81}

Generalized Prime Recharge for Aquifers of Primary Use: Miami Sheet, compiled by K. Campbell, J. Lloyd, and T. Scott, 1993. Scale: 1:250,000.

\section{OFMS 82}

Generalized Prime Recharge for Aquifers of Primary Use: Key West Sheet (Note: No prime recharge to aquifers of primary use in this area), 1993. Scale: 1:250,000.

\section{OFMS 83-01-83-07 品 \$14.00/set}

Surficial and Bedrock Geology of the Eastern Portion of the U.S.G.S. 1:100,000 Scale Homestead Quadrangle, by R. Green, K. Campbell, and T. Scott, 1995. 7 sheets, bound. STATEMAP. Note: see individual sheets listed below. Order individual sheets or bound set.

\section{OFMS 83-01}

Bedrock Geology of the Eastern Portion of the U.S.G.S. 1:100,000 Scale Homestead Quadrangle, by R. Green, K. Campbell, and T. Scott, 1995.

\section{OFMS 83-02}

Surficial Sediment Map of the Eastern Portion of the U.S.G.S. 1:100,000 Scale Homestead Quadrangle, by R. Green, K. Campbell, and T. Scott, 1995.

\section{OFMS 83-03}

North-South Geologic Cross Section A-A' Through the Eastern Portion of the U.S.G.S. 1:100,000 Scale Homestead Quadrangle, by R. Green, K. Campbell, and T. Scott, 1995.

\section{OFMS 83-04}

North-South Geologic Cross Section B-B' Through the Eastern Portion of the U.S.G.S. 1:100,000 Scale Homestead Quadrangle, by R. Green, K. Campbell, and T. Scott, 1995.

\section{OFMS 83-05}

North-South Geologic Cross Section C-C' Through the Eastern Portion of the U.S.G.S. 1:100,000 Scale Homestead Quadrangle, by R. Green, K. Campbell, and T. Scott, 1995.

\section{OFMS 83-06}

West-East Geologic Cross Section D-D' Through the Eastern Portion of the U.S.G.S. 1:100,000 Scale Homestead Quadrangle, by R. Green, K. Campbell, and T. Scott, 1995.

OFMS 83-07

West-East Geologic Cross Section E-E' Through the Eastern Portion of the U.S.G.S. 1:100,000 Scale Homestead Quadrangle, by R. Green, K. Campbell, and T. Scott, 1995.

OFMS 83-08-83-12 品 $\$ 10.00$

Surficial and Bedrock Geology of the Western Portion of the U.S.G.S. 1:100,000 Scale Homestead Quadrangle, by R. Green, K. Campbell, and T. Scott, 1996. 5 sheets, bound.

Note: see individual sheets listed below. Order individual sheets or bound set.

\section{OFMS 83-08}

Bedrock Geology of the Western Portion of the U.S.G.S. 1:100,000 Scale Homestead Quadrangle, by R. Green, K. Campbell, and T. Scott, 1996.

\section{OFMS 83-09}

Surficial Sediment Map of the Western Portion of the U.S.G.S. 1:100,000 Scale Homestead Quadrangle, by R. Green, and K. Campbell, 1996.

OFMS 83-10

West-East Geologic Cross Section A-A' Through the Western Portion of the U.S.G.S. 1:100,000 Scale Homestead Quadrangle, by R. Green, K. Campbell, and T. Scott, 1996. 
OFMS 83-11

West-East Geologic Cross Section B-B' Through the Western Portion of the U.S.G.S. 1:100,000 Scale Homestead Quadrangle, by R. Green, K. Campbell, and T. Scott, 1996.

OFMS 83-12

North-South Geologic Cross Section C-C' Through the Western Portion of the U.S.G.S. 1:100,000 Scale Homestead Quadrangle, by R. Green, K. Campbell, and T. Scott, 1996.

OFMS 84 品

Top of Rock of the Floridan Aquifer System in the Suwannee River Water Management District, by D. Allison, M. Groszos, and F. Rupert, 1995. Scale: 1:475,000.

\section{OFMS 86-01-86-08 屌 \$16.00/set}

Surficial and Bedrock Geology of the Western Portion of the U.S.G.S. 1:100,000 Scale Sarasota Quadrangle, by R. Green, T. Scott, K. Campbell, J. Arthur, and G.H. Means, 1997. 8 sheets, bound. STATEMAP. Note: see individual sheets listed below. Order individual sheets or bound set.

\section{OFMS 86-01}

Geologic Map of the Western Portion of the U.S.G.S. 1: 100,000 Scale Sarasota Quadrangle, by R. Green, K. Campbell, J. Arthur, and T. Scott, 1997.

\section{OFMS 86-02}

Surficial Sediments of the Western Portion of the U.S.G.S. 1:100,000 Scale Sarasota Quadrangle, by G.H. Means and R. Green, 1997.

\section{OFMS 86-03}

West-East Geologic Cross Section A-A' Through the Western Portion of the U.S.G.S. 1:100,000 Scale Sarasota Quadrangle, by R. Green, J. Arthur, K. Campbell, and T. Scott, 1997.

\section{OFMS 86-04}

West-East Geologic Cross Section B-B' Through the Western Portion of the U.S.G.S. 1:100,000 Scale Sarasota Quadrangle, by R. Green, J. Arthur, K. Campbell, and T. Scott, 1997.

OFMS 86-05

West-East Geologic Cross Section C-C' Through the Western Portion of the U.S.G.S. 1:100,000 Scale Sarasota Quadrangle, by R. Green, J. Arthur, K. Campbell, and T. Scott, 1997.

\section{OFMS 86-06}

North-South Geologic Cross Section D-D' Through the Western Portion of the U.S.G.S. 1:100,000 Scale Sarasota Quadrangle, by R. Green, J. Arthur, K. Campbell, and T. Scott, 1997.

\section{OFMS 86-07}

North-South Geologic Cross Section E-E' Through the Western Portion of the U.S.G.S. 1:100,000 Scale Sarasota Quadrangle, by R. Green, J. Arthur, K. Campbell, and T. Scott, 1997.

\section{OFMS 86-08}

North-South Geologic Cross Section F-F' Through the Western Portion of the U.S.G.S. 1:100,000 Scale Sarasota Quadrangle, by R. Green, J. Arthur, K. Campbell, and T. Scott, 1997.

\section{OFMS 87-01-87-08 品 \$16.00/set}

Surficial and Bedrock Geology of the Eastern Portion of the U.S.G.S. 1:100,000 Scale Sarasota Quadrangle and the Western Portion of the U.S.G.S. 1:100,000 Scale Arcadia Quadrangle, South-Central Florida, by R. Green, T. Scott, K. Campbell, and G.H. Means, 1998. 8 sheets, bound. STATEMAP. Note: see individual sheets listed below. Order individual sheets or bound set.

\section{OFMS 87-01}

Geologic Map of the Eastern Portion of the U.S.G.S. 1:100,000 Scale Sarasota Quadrangle and the Western Portion of the U.S.G.S. 1:100,000 Scale Arcadia Quadrangle, South-Central Florida, by R. Green, T. Scott, K. Campbell, and G.H. Means, 1998.

\section{OFMS 87-02}

Surficial Sediments of the Eastern Portion of the U.S.G.S. 1:100,000 Scale Sarasota Quadrangle and the Western Portion of the U.S.G.S. 1:100,000 Scale Arcadia Quadrangle, South-Central Florida, by G.H. Means and R. Green, 1998. 
OFMS 87-03

West-East Geologic Cross Section A-A' Through the Eastern Portion of the U.S.G.S. 1:100,000 Scale Sarasota Quadrangle and the Western Portion of the U.S.G.S. 1:100,000 Scale Arcadia Quadrangle, South-Central Florida, by R. Green, G.H. Means, K. Campbell, and T. Scott, 1998.

\section{OFMS 87-04}

West-East Geologic Cross Section B-B' Through the Eastern Portion of the U.S.G.S. 1:100,000 Scale Sarasota Quadrangle and the Western Portion of the U.S.G.S. 1:100,000 Scale Arcadia Quadrangle, South-Central Florida, by R. Green, G.H. Means, K. Campbell, and T. Scott, 1998.

\section{OFMS 87-05}

West-East Geologic Cross Section C-C' Through the Eastern Portion of the U.S.G.S. 1:100,000 Scale Sarasota Quadrangle and the Western Portion of the U.S.G.S. 1:100,000 Scale Arcadia Quadrangle, South-Central Florida, by R. Green, G.H. Means, K. Campbell, and T. Scott, 1998.

\section{OFMS 87-06}

North-South Geologic Cross Section D-D' Through the Eastern Portion of the U.S.G.S. 1:100,000 Scale Sarasota Quadrangle and the Western Portion of the U.S.G.S. 1:100,000 Scale Arcadia Quadrangle, South-Central Florida, by R. Green, G.H. Means, K. Campbell, and T. Scott, 1998.

\section{OFMS 87-07}

North-South Geologic Cross Section E-E' Through the Eastern Portion of the U.S.G.S. 1:100,000 Scale Sarasota Quadrangle and the Western Portion of the U.S.G.S. 1:100,000 Scale Arcadia Quadrangle, South-Central Florida, by R. Green, G.H. Means, K. Campbell, and T. Scott, 1998.

\section{OFMS 87-08}

North-South Geologic Cross Section F-F' Through the Eastern Portion of the U.S.G.S. 1:100,000 Scale Sarasota Quadrangle and the Western Portion of the U.S.G.S. 1:100,000 Scale Arcadia Quadrangle, South-Central Florida, by R. Green, G.H. Means, K. Campbell, and T. Scott, 1998.

\section{OFMS 88-01-88-08 品 \$16.00/set}

Surficial and Bedrock Geology of the Eastern Portion of the U.S.G.S. 1:100,000 Scale Arcadia Quadrangle, SouthCentral Florida, by R. Green, G.H. Means, T. Scott, J. Arthur, and K. Campbell, 1999. 8 sheets, bound. STATEMAP. Note: see individual sheets listed below. Order individual sheets or bound set.

\section{OFMS 88-01}

Geologic Map of the Eastern Portion of the U.S.G.S. 1:100,000 Scale Arcadia Quadrangle, South-Central Florida, by R. Green, G.H. Means, T. Scott, J. Arthur, and K. Campbell, 1999.

OFMS 88-02

Surficial Sediments of the Eastern Portion of the U.S.G.S. 1:100,000 Scale Arcadia Quadrangle, South-Central Florida, by G.H. Means and R. Green, 1999.

\section{OFMS 88-03}

West-East Geologic Cross Section A-A' Through the Eastern Portion of the U.S.G.S. 1:100,000 Scale Arcadia Quadrangle, South-Central Florida, by R. Green, T. Scott, and G.H. Means, 1999.

\section{OFMS 88-04}

West-East Geologic Cross Section B-B' Through the Eastern Portion of the U.S.G.S. 1:100,000 Scale Arcadia Quadrangle, South-Central Florida, by R. Green, T. Scott, and G.H. Means, 1999.

\section{OFMS 88-05}

West-East Geologic Cross Section C-C' Through the Eastern Portion of the U.S.G.S. 1:100,000 Scale Arcadia Quadrangle, South-Central Florida, by R. Green, T. Scott, and G.H. Means, 1999.

\section{OFMS 88-06}

North-South Geologic Cross Section D-D' Through the Eastern Portion of the U.S.G.S. 1:100,000 Scale Arcadia Quadrangle, South-Central Florida, by R. Green, T. Scott, and G.H. Means, 1999.

\section{OFMS 88-07}

North-South Geologic Cross Section E-E' Through the Eastern Portion of the U.S.G.S. 1:100,000 Scale Arcadia Quadrangle, South-Central Florida, by R. Green, T. Scott, and G.H. Means, 1999. 


\section{OFMS 88-08}

North-South Geologic Cross Section F-F' Through the Eastern Portion of the U.S.G.S. 1:100,000 Scale Arcadia Quadrangle, South-Central Florida, by R. Green, T. Scott, and G.H. Means, 1999.

\section{OFMS 89 品 $\$ 4.00$}

Surficial and Bedrock Geology of the Northern Portion of the U.S.G.S. 1:100,000 Scale Crestview Quadrangle, Northwestern Florida, by G.H. Means, R.C. Green, J.R. Bryan, T.M. Scott, K.M. Campbell, M.M. Gaboardi, and J.D. Robertson, 2000, 2 sheets. STATEMAP.

\section{OFMS 90 品 $\$ 4.00$}

Surficial and Bedrock Geology of the Southern Portion of the U.S.G.S. 1:100,000 Scale Crestview Quadrangle, Northwestern Florida, by R.C. Green, G.H. Means, T.M. Scott, M.M. Gaboardi, W.L. Evans, D.T. Paul, and K.M. Campbell, 2001, 2 sheets. STATEMAP.

\section{OFMS 91 品 $\$ 4.00$}

Surficial and Bedrock Geology of the Western Portion of the U.S.G.S. 1:100,000 Scale Marianna Quadrangle, Northwestern Florida, by R.C. Green, W.L. Evans, J.R. Bryan, D.T. Paul, and M.M. Gaboardi, 2 sheets. STATEMAP.

\section{OFMS 92 品 $\$ 4.00$}

Surficial and Bedrock Geology of the Eastern Portion of the U.S.G.S. 1:100,000 Scale Marianna Quadrangle, Northwestern Florida, by R.C. Green, W.L. Evans, J.R. Bryan, and D.T. Paul, 2003, 2 sheets. STATEMAP.

\section{OFMS 93 맸 $\$ 4.00$}

Geologic Map of the Western Portion of the U.S.G.S. 1:100,000 Scale Gainesville Quadrangle, Northern Florida, by W.L. Evans, R.C. Green, J.R. Bryan, and D. T. Paul, 2004, 2 sheets. STATEMAP.

\section{OFMS 94 品 $\$ 4.00$}

Geologic Map of the Eastern Portion of the U.S.G.S. 1:100,000 Scale Gainesville Quadrangle, Northern Florida, by R.C. Green, W.L. Evans III, D.T. Paul, and T.M. Scott, 2005. Scale: 1:100,000, 2 sheets. STATEMAP.

\section{OFMS 95 品 $\$ 2.00$}

Florida Springs Protection Areas, by T.H. Greenhalgh and A.E. Baker, 2005, 1 sheet.

\section{OFMS 97 回 $\$ \mathbf{\$ 4 . 0 0}$}

Geologic Map of the Western Portion of the U.S.G.S. 1:100,000 Scale Lake City Quadrangle, Northern Florida, by R.C. Green, D.T. Paul, W.L. Evans III, T.M. Scott, and S.B. Petrushak, 2006. Scale: 1:100,000, 2 sheets. STATEMAP.

\section{OFMS 98 品 $\$ 4.00$}

Geologic map of the eastern portion of the U.S.G.S. Perry $30 \times 60$ minute quadrangle, northern Florida [3 plates], by R.C. Green, D.T. Paul, S.B. Petrushak, C. Kromhout, and T.M. Scott, 2007. Scale: 1:100,000. STATEMAP. Includes Open-File Report 91, Text to accompany geologic map of the eastern portion of the U.S.G.S. Perry $30 \times 60$ minute quadrangle, northern Florida, by R.C. Green, D.T. Paul, and T.M. Scott, 2007, 32 p.

\section{OFMS 99 맸 $\$ 4.00$}

Geologic map of the western portion of the U.S.G.S. Perry 30 x 60 minute quadrangle, northern Florida [3 plates], by R.C. Green, D.T. Paul, D.J. Wagner, C. Kromhout, and T. M. Scott, 2008. Scale: 1:100,000. STATEMAP. Includes Open-File Report 92, Text to accompany geologic map of the western portion of the U.S.G.S. Perry 30 x 60 minute quadrangle, northern Florida, by R.C. Green, D.T. Paul, and T.M. Scott, 2008, 35 p.

\section{OFMS 100 品 $\$ 4.00$}

Geologic map of the eastern portion of the U.S.G.S. Ocala $30 \times 60$ minute quadrangle, north-central Florida [3 plates], by R.C. Green, C.P. Williams, D.T. Paul, C. Kromhout, and T.M. Scott, 2009. Scale: 1:100,000. STATEMAP. Includes Open-File Report 93, Text to accompany geologic map of the eastern portion of the U.S.G.S. Ocala $30 \times 60$ minute quadrangle, north-central Florida, by R.C. Green, C.P. Williams, D.T. Paul, C. Kromhout, and T.M. Scott, 2009,28 p.

\section{OFMS 101 品 $\$ 4.00$}

Geologic map of the western portion of the U.S.G.S. Ocala $30 \times 60$ minute quadrangle, north-central Florida [3 plates], by R.C. Green, C.P. Williams, A.D. Flor, D.T. Paul, C. Kromhout, and T.M. Scott, 2010. Scale: 1:100,000. STATEMAP. Includes Open-File Report 94, Text to accompany geologic map of the western portion of the U.S.G.S. Ocala $30 \times 60$ minute quadrangle, north-central Florida, by C.P. Williams, R.C. Green, A.D. Flor, D.T. Paul, T.M. Scott, and C. Kromhout, 2010, 29 p. 


\section{OFMS 102 品 $\$ 4.00$}

Geologic map of the eastern portion of the U.S.G.S. Inverness $30 \times 60$ minute quadrangle, central Florida [3 plates], by R.C. Green, C.P. Williams, K.E. Burdette, S.W. Bassett, A.D. Flor and D.T. Paul, 2011. Scale: 1:100,000. STATEMAP. Includes Open-File Report 96, Text to accompany geologic map of the eastern portion of the U.S.G.S. Inverness $30 \times 60$ minute quadrangle, central Florida, by C.P. Williams, K.E. Burdette, R.C. Green, S.W. Bassett, A.D. Flor, and D. T. Paul, 2011, 40 p.

\section{OFMS 103 品 $\$ 4.00$}

Geologic map of the western portion of the U.S.G.S. Inverness $30 \times 60$ minute quadrangle, central Florida [3 plates], by C.P. Williams, R.C. Green, S.W. Bassett, L.M. Hannon and A.D. Flor, 2012. Scale 1:100,000. STATEMAP. Includes OpenFile Report 97, Text to accompany geologic map of the western portion of the U.S.G.S. Inverness $30 \times 60$ minute quadrangle, central Florida, by C.P. Williams and R.C. Green, 2012, 29 p.

\section{OFMS 104 品 $\$ 4.00$}

Geologic map of the U.S.G.S. Tarpon Springs 30 × 60 minute quadrangle, central Florida [3 plates], by R.C. Green, W.L. Evans, C.P. Williams, C. Kromhout, S.W. Bassett, and L.M. Hannon, 2012. Scale: 1:100,000. STATEMAP. Includes Open-File Report 98, Text to accompany geologic map of the U.S.G.S. Tarpon Springs $30 \times 60$ minute quadrangle, central Florida, by R.C. Green, W.L. Evans III, C.P. Williams, C. Kromhout, and L.M. Hannon, 2012, 40 p.

\section{OFMS 105 매료 $\$ 4.00$}

Geologic map of the U.S.G.S. Daytona Beach 30 x 60 minute quadrangle, northeast Florida [3 plates], by R.C. Green, W.L. Evans III, S. W. Bassett, and L.M. Hannon, 2013. Scale: 1:100,000. STATEMAP. Includes Open-File Report 101, Text to accompany geologic map of the U.S.G.S. Daytona Beach 30 × 60 minute quadrangle, northeast Florida, by R. C. Green, W. L. Evans III, and S.W. Bassett, 2013, 37 p.

\section{OFMS 106 品 $\$ 4.00$}

Geologic map of the U.S.G.S. Saint Augustine $30 \times 60$ minute quadrangle, northeast Florida [3 plates], by R.C. Green, C.P. Williams, K.M. Campbell, P.W. Bambach, L.M. Hannon, S.W. Bassett, W.L. Evans III, D.T. Paul, and B. Apolinar, 2014. Scale: 1:100,000. STATEMAP. Includes Open- File Report 102, Text to accompany geologic map of the U.S.G.S. Saint Augustine 30 x 60 minute quadrangle, northeast Florida, by R.C. Green, C.P. Williams, K.M. Campbell,

P.W. Bambach, L.M. Hannon, S.W. Bassett, W.L. Evans III, D.T. Paul, and B. Apolinar, 2014, 34 p.

\section{OFMS 107 品 $\$ 4.00$}

Geologic map of the U.S.G.S. Orlando $30 \times 60$ minute quadrangle, central Florida [3 plates], by R.C. Green, C.P. Williams, P.W. Bambach, L.M. Hannon, B. Apolinar, K.M. Campbell, and S.B. Dyer, 2015. Scale: 1:100,000. STATEMAP. Includes Open-File Report 104, Text to accompany geologic map of the U.S.G.S. Orlando 30 x 60 minute quadrangle, central Florida, by R.C. Green, C.P. Williams, P.W. Bambach, L.M. Hannon, B. Apolinar, K.M. Campbell, and S.B. Dyer, 2015, 37 p.

\section{OFMS 108 品 $\$ 4.00$}

Geologic map of the U.S.G.S. Jacksonville 30 x 60 minute quadrangle, northeast Florida [3 plates], by R.C. Green, C.P. Williams, P.W. Bambach, B. Apolinar, L. M. Hannon, and K.M. White, 2016. Scale 1:100,000. STATEMAP. Includes OpenFile Report 105, Text to accompany geologic map of the U.S.G.S. Jacksonville $30 \times 60$ minute quadrangle, northeast Florida, by R.C. Green, C.P. Williams, P.W. Bambach, B. Apolinar, L.M. Hannon, and K.M. White, 2016,31 p.

\section{OFMS 109 品 $\$ 4.00$}

Geologic map of the U.S.G.S. Saint Petersburg $30 \times 60$ minute quadrangle, west-central Florida [3 plates], by R.C. Green, B. Apolinar, C.P. Williams, K.M. White, S.W. Bassett, and L.F. Nason, 2017. Scale 1:100,000. STATEMAP. Includes OpenFile Report 106, Text to accompany geologic map of the U.S.G.S. Saint Petersburg 30 x 60 minute quadrangle, westcentral Florida, by R.C. Green, B. Apolinar, C.P. Williams, K.M. White, S.W. Bassett, and L.F. Nason, 2017,41 p.

\section{OFMS $110 \quad$ 品 $\$ 4.00$}

Geologic map of the USGS Kissimmee $30 \times 60$ minute quadrangle, central Florida [3 plates], by R.C. Green, C.P. Williams, A.G. Lamarche, C.K. Albritton, K.M. White, and S.W. Bassett, 2018. Scale 1:100,000. STATEMAP. Includes Open-File Report 107, Text to accompany geologic map of the USGS Kissimmee $30 \times 60$ minute quadrangle, central Florida, by R.C. Green, C.P. Williams, A.G. Lamarche, C.K. Albritton, K.M. White, and S.W. Bassett, 2018, 42 p.

\section{OFMS $111 \quad$ 足 $\$ 4.00$}

Geologic map of the USGS Bartow $30 \times 60$ minute quadrangle central Florida [3 plates], by R.C. Green, C.P. Williams, A.G. Lamarche, C.L. Hebets, C.K. Albritton, and G.S. Evans, 2019. Scale 1:100,000. STATEMAP. Includes Open-File Report 108, Text to accompany geologic map of the USGS Bartow $30 \times 60$ minute quadrangle central Florida, by R.C. Green, C.P. Williams, A.G. Lamarche, C.L. Hebets, C.K. Albritton, and G.S. Evans, 2019, 38 p. 


\section{OFMS 112 매요 $\quad \$ 4.00$}

Green, R.C., Lamarche, A.G., Williams, C.P., Hebets, C.L., Evans, G.S., and Albritton, C.K., 2021, Geologic map of the USGS Vero Beach $30 \times 60$ minute quadrangle central Florida. Scale 1:100,000. 3 plates. STATEMAP. Includes Open-File Report 109, Green, R.C., Lamarche, A.G., Williams, C.P., Hebets, C.L., Evans, G.S., and Albritton, C.K., 2021, Text to accompany geologic map of the USGS Vero Beach 30 × 60 minute quadrangle central Florida, 38 p.

\section{OFMS 113 品 $\$ \mathbf{\$ 4 . 0 0}$}

Green, R.C., Williams, C.P., Hebets, C.L., Greene, J.W., Hall, N.P., Evans, G.S., and Duffey, B.M., 2022, Geologic map of the USGS Fort Pierce $30 \times 60$ minute quadrangle south Florida. Scale 1:100,000. 3 plates. STATEMAP. Includes Open-File Report 110, Green, R.C., Williams, C.P., Hebets, C.L., Greene, J.W., Hall, N.P., Evans, G.S., and Duffey, B.M., 2022, Text to accompany geologic map of the USGS Fort Pierce 30 x 60 minute quadrangle south Florida, 32 p. 


\section{OPEN FILE REPORTS}

Open File Reports (OFR) present the results of geologic investigations in an informal format and may serve as interim reports of ongoing projects. These items are print-on-demand.

\section{OFR 1 믈 OUT OF PRINT}

The Hawthorn Formation of Northeastern Florida, Part I: The Geology of the Hawthorn Formation of Northeastern Florida, by T.M. Scott, 1982, 45 p., 14 fig., appendix. (Updated by Report of Investigations 94)

OFR 2 믄 OUT OF PRINT

Dissertations and Theses on Geology Completed at Florida Universities, compiled by M.A. Cleveland, 1983, 36 p. (Updated by Special Publication 39)

OFR 3 뭉 $\quad \$ 2.00$

Notes on the Geology of Walton County, by W. Schmidt, 1984, 23 p., 3 pl.

OFR 4 므 OUT OF PRINT

An Overview of Peat in Florida and Related Issues, by P. Bond, 1984, 228 p., 28 fig., 9 tables. (Updated by Special Publication 27)

OFR 5 묭 $\$ 2.00$

Geology of Citrus County, Florida, by S. Spencer, 1984, 18 p., 3 fig.

OFR 6 믕 $\$ 2.00$

Geology of Hillsborough County, Florida, by K.M. Campbell, 1984, 20 p., 3 fig.

OFR 7 믐 OUT OF PRINT

Geology of Sumter County, by K.M. Campbell, 1984, 12 p., 4 fig. (Updated by Report of Investigations 98)

OFR 8 䓛 $\$ 2.00$

St. Vincent Island (St. Vincent National Wildlife Refuge), by K.M. Campbell, 1984 (rev.), 18 p., 5 fig.

OFR 9 몽 $\quad \$ 2.00$

Alum Bluff, Liberty County, Florida, by K.M. Campbell, 1985, 11 p., 2 fig.

OFR 10 을 $\$ 2.00$

Geology of Sarasota County, Florida, by K.M. Campbell, 1985, 15 p., 6 fig.

OFR 11 品 $\$ 2.00$

Geology of DeSoto County, Florida, by K.M. Campbell, 1985, 13 p., 4 fig.

OFR 12 을 $\$ 2.00$

Geology and Groundwater of Madison County, by R.W. Hoenstine and S.M. Spencer, 1986, 15 p., 4 fig.

OFR 13 㗊 $\$ 2.00$

Geology of Polk County, Florida, by K.M. Campbell, 1986, 14 p., 4 fig.

OFR 14 品 $\$ 2.00$

Status of Phosphatic Clay Waste Disposal, by J.W. Yon, 1983, 30 p., 13 fig.

OFR 15 品 $\$ 2.00$

The Lithostratigraphy of Nassau County in Relation to the Superconducting Supercollider Site Investigation, by T.M. Scott, 1987, 56 p., 16 fig., 2 tables.

OFR 16 啹 $\$ 2.00$

Geology of Union County, Florida by F. Rupert, 1987, 13 p., 3 fig.

OFR 17 薦 $\$ 2.00$

Geology of Bradford County, Florida by F. Rupert, 1987, 14 p., 3 fig.

OFR 18 品 $\$ 2.00$

The Geology and Geomorphology of Gilchrist County, Florida, by F. Rupert, 1988, 10 p., 4 fig. 
OFR 19 最 $\$ 2.00$

Geology and Geomorphology of Levy County, Florida, by F.R. Rupert, 1988, 18 p., 3 fig.

OFR 20 䓛 $\$ 2.00$

Leon Sinks Special Interest Area, by E. Lane, 1988, 5 p.

OFR 21 点 $\$ 2.00$

Geologic Interpretation of the Aquifer Pollution Potential in Alachua County, Florida, by M. Macesich, 1988,25 p., 3 fig.

OFR 22 品 $\$ 2.00$

The Geology of Wakulla Springs, by F.R. Rupert, 1988, 18 p., 5 fig.

OFR 23 品 $\$ 2.00$

Florida Caverns State Park, Jackson County, Florida, by W. Schmidt, 1988, 7 p., 1 fig.

OFR 24 品 $\$ 2.00$

The Geology of Flagler County, Florida, by J.D. Arthur, 1988, 13 p., 3 fig.

OFR 25 品 $\$ 2.00$

The Geology of Collier County, Florida, by K.M. Campbell, 1988, 14 p., 4 fig.

OFR 26 薦 $\$ 2.00$

Stratigraphic Correlation of Outcrop Gamma Ray Profiles in Florida, by R.A. Johnson, 1989, 29 p., 16 fig.

OFR 27 屌 $\$ 2.00$

The Geology of Hamilton County, Florida, by F.R. Rupert, 1989, 5 p., 2 fig.

OFR 28 品 $\$ 2.00$

Heavy-Mineral Reconnaissance off the Gulf Coast of Northwest Florida, by the Florida Geological Survey, 1988,66 p.

OFR 29 品 $\$ 2.00$

Characterization of the Sediments Overlying the Floridan Aquifer System in Alachua County, Florida, by R. Green,

J. Duncan, T. Seal, J.M. Weinberg, and F. Rupert, 1989, 114 p.

OFR 30 品 $\$ 2.00$

Summary of the Geology of Glades County, Florida, by K.M. Campbell, 1990, 11 p., 4 figures.

OFR 31 䓛 $\$ 2.00$

A Brief Overview of Miocene Lithostratigraphy - Northern Florida and Eastern Georgia, by T.M. Scott, 1990,6 p.

OFR 32 呢 $\$ 2.00$

The Geomorphology and Geology of Calhoun County, Florida, by F.R. Rupert, 1990, 7 p.

OFR 33 点 $\$ 2.00$

The Geomorphology, Geology and Hydrogeology of Baker County, Florida, by P. Bond, 1990, 16 p.

OFR 34 吊 $\$ 2.00$

The Geology and Geomorphology of Florida's Coastal Marshes, by F.R. Rupert and J.D. Arthur, 1990, 13 p.

OFR 35 \$2.00

Sand, Gravel and Heavy-Mineral Resources Potential of Surficial Sediments Offshore of Cape Canaveral, Florida, by B.W. Nocita, P. Kohpina, L.W. Papetti, M.M. Olivier, A.E. Grosz, S. Snyder, K.M. Campbell, R.C. Green, and

T.M. Scott, 1990, 55 p.

OFR 36 品 $\$ 2.00$

The Lithostratigraphy of the Hawthorn Group of Peninsular Florida, by T.M. Scott, 1990, 12 p.

OFR 37 遍 $\$ 2.00$

Core Drilling Project: Lee, Hendry and Collier Counties, by R.C. Green, K.M. Campbell, and T.M. Scott, 1990, 44 p.

OFR 38 品 $\$ 2.00$

Licensing of Geologists in Florida: A Result of the Population/ Development Explosion and Political Environmental Awareness, by W. Schmidt, 1990, 5 p. 
OFR 39 喝 $\$ 2.00$

Sand, Gravel and Heavy-Mineral Resource Potential of Holocene Sediments Offshore of Florida, Cape Canaveral to the Georgia Border: Phase I, by B.W. Nocita, L.W. Papetti, A.E. Grosz, and K.M. Campbell, 1991, 107 p.

\section{OFR 40 鴯 $\$ 2.00$}

Earthquakes and Seismic History of Florida, by E. Lane, 1991, 11 p. (Updates Information Circular 93)

\section{OFR 41 呢 $\$ 2.00$}

Radon Potential Study, Alachua County, Florida: Near-Surface Stratigraphy and Results of Drilling, by K.M.

Campbell and T.M. Scott, 1991, 42 p.

\section{OFR 42 呢 $\$ 2.00$}

A Gamma-Ray Profile Investigation of the Upper Pleistocene Miami Limestone of South Florida, by R.A. Johnson, 1991, 15 p.

\section{OFR 43 品 $\$ 2.00$}

The Geomorphology and Geology of Liberty County, Florida, by F.R. Rupert, 1991, 9 p.

\section{OFR 44 回 $\$ 2.00$}

Florida's Oil and Gas Reserves for 1991, by C.H. Tootle, 1991, 8 p.

\section{OFR 45 佪 $\$ 2.00$}

The Geomorphology and Geology of Dixie County, Florida, by F.R. Rupert, 1991, 6 p.

\section{OFR 46 品 $\$ 2.00$}

The Geomorphology, Geology and Hydrogeology of Lafayette County, Florida, by J.D. Arthur, 1991,10 p.

\section{OFR 47 圆 $\$ 2.00$}

Lithology and Palynology of Cave Floor Sediment Cores from Wakulla Spring, Wakulla County, Florida, by F. Rupert, 1991, $9 \mathrm{p}$.

\section{OFR 48 恶 $\$ 2.00$}

Lithologic Variation in the Miami Limestone of Florida, by R.A. Johnson, 1992, 26 p.

\section{OFR 50 品 \$2.00 OUT OF PRINT}

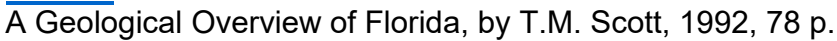

\section{OFR 51 䓛 $\$ 2.00$}

Geomorphology, Geology, and Hydrogeology of the Savannas State Reserve, Martin and St. Lucie Counties, Florida, by F.R. Rupert, 1992, 8 p.

\section{OFR 52 品 $\$ 2.00$}

Editorial Preparation of Florida Geological Survey Publications, E. Lane, 1992, 29 p.

\section{OFR 53 薦 $\$ 2.00$}

Guidelines for Authors, by E. Lane, 1992, 42 p. (Updates Special Publication 23).

\section{OFR 54 品 $\$ 2.00$}

Carbonate Units of the Intermediate Aquifer System in the Suwannee River Water Management District, by M.

Groszos, R. Ceryak, D. Allison, R. Cooper, M. Weinberg, M. Macesich, M.M. Enright, and F. Rupert, 1992,22 p.

\section{OFR 55 昌 $\$ 2.00$}

Neutron Log Signature of the Pliocene Tamiami Formation in Brevard and Indian River Counties, East-Central Peninsular Florida, by R.A. Johnson, 1993, 22 p.

\section{OFR 56 品 $\$ 2.00$}

Sarasota County Intermediate Aquifer System Core Drilling and Analysis, by K.M. Campbell, T.M. Scott, R. Green, and W.L. Evans, III, 1993, 21 p.

OFR 57 邑 $\$ 2.00$

An Overview of Florida Marine Mining and Marine Oil and Gas Production Regulations, by C.B. Garrett, 1993,5 p.

OFR 58 品 $\$ 2.00$

Florida Sinkhole Index, by S.M. Spencer and E. Lane, 1994, 18 p. 
OFR 59 品 $\$ 2.00$

Geomorphology and Geology of Escambia County, Florida, by F.R. Rupert, 1993, 6 p.

OFR 60 啹 $\$ 2.00$

The Geology of Warm Mineral Springs, Sarasota County, Florida, by F.R. Rupert, 1994, 7 p.

OFR 61 点 $\$ 2.00$

Lithostratigraphic and Hydrostratigraphic Cross Sections Through Pinellas and Hillsborough Counties, Southwest Florida, by R. Green, J.D. Arthur, and D. DeWitt, 1995, 26 p., 6 plates.

\section{OFR 62 品 $\$ 2.00$}

Core Drilling and Analysis: City of Sarasota, Downtown Well Field (revised), by K.M. Campbell, T.M. Scott, and R.C. Green. 1995, 16 p.

OFR 63 品 $\$ 2.00$

A Fossil Hunter's Guide to the Geology of Panhandle Florida, by F.R. Rupert, 1994, 11 p.

OFR 64 呢 $\$ 2.00$

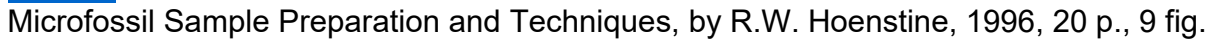

OFR 65 品 $\$ 2.00$

A Fossil Hunter's Guide to the Geology of the Northern Florida Peninsula, by F.R. Rupert, 1994, 12 p.

OFR 66 䓛 $\$ 2.00$

A Fossil Hunter's Guide to the Geology of Southern Florida, by T.M. Scott and F.R. Rupert, 1994, 12 p.

OFR 67 䓛 $\$ 2.00$

Topographic Maps: Useful Tools for the Florida Fossil Hunter, by F.R. Rupert, 1995, 11 p.

OFR 69 品 $\$ 2.00$

A Geological Investigation of the Offshore Area Along Florida's Central East Coast: Year 1, by H. Freedenberg, R. Hoenstine, Z.Q. Chen and H. Williams, 1995, 97 p.

\section{OFR 70 屌 $\$ 2.00$}

The Geomorphology and Geology of Taylor County, Florida, by F.R. Rupert, 1996, 7 p.

OFR 71 品 $\$ 2.00$

Economic Geology of the Heavy Mineral Placer Deposits in Northeastern Florida, by H. Elsner, 1997, 137 p.

OFR $72 \square \quad \$ 2.00$

Geologic and Geotechnical Assessment for the Evaluation of Sinkhole Claims, (reprint from Insurance Study of Sinkholes, Chapters V and VI, 1992) 1997. 40 p.

\section{OFR 73 吕 $\$ 2.00$}

Open-Ocean Water Level Datum Planes for Monumented Coasts of Florida, by J.H. Balsillie, J.G. Carlen, and T.M. Waters, 1998, 92 p.

\section{OFR 74 品 $\$ 2.00$}

Mineral Resources of Jackson County, Florida, by S.M. Spencer and J.M. Lloyd, 1999, 15 p.

\section{OFR 75 啹 $\$ 2.00$}

Mineral Resources of Escambia County, Florida, by S.M. Spencer, E. Lane, and R.W. Hoenstine, 1999,14 p.

\section{OFR 76 葛 $\$ \mathbf{2 . 0 0}$}

Annotated Bibliography of Mercury Studies Related to the Environment and Geologic Setting of Florida, by P. Bond, 1998, 56 p.

\section{OFR 78 虽 $\$ 2.00$}

Volumetric Beach and Coast Erosion Due to Storm and Hurricane Impact, by J.H. Balsillie, 1999,37 p. 
OFR 80 量 $\$ 2.00$

Text to accompany the Geologic Map of Florida (MS 146), by T.M. Scott, 2001, 29 p. Included with $\$ 7.50$ price of MS 146.

\section{OFR 81 욜 $\quad \$ 2.00$}

Lithostratigraphic and Hydrostratigraphic Cross Sections Through Levy-Marion to Pasco Counties, Southwest

Florida, by J.D. Arthur, R.A. Lee and L. Li, 2001, 31 p.

\section{OFR 83 品 $\$ 2.00$}

Florida Aquifer Storage and Recovery Geochemical Study: Year Three Progress Report, by J.D. Arthur, J.B. Cowart, and A.A. Dabous, 2001, 52 p.

\section{OFR 84 品 $\$ 2.00$}

Moment Versus Graphic Measures in Granulometry, by J.H. Balsillie, A.A. Dabous, C.T. Fischler, 2002,86 p.

\section{OFR 85 묘료 OUT OF PRINT}

First Magnitude Springs of Florida, by T.M. Scott, G.H. Means, R.C. Means and R.P. Meegan, 2002, 138 p.

\section{OFR 86 品 $\$ 2.00$}

Geology of Suwannee County, Florida, by F.R. Rupert, 2003, 9 p.

\section{OFR 87 薦 $\$ 2.00$}

A New Type of Sieve Shaker: The Meinzer II, A Comparative Study with Rotap Technology, by J.H. Balsillie and A.A. Dabous, 2003, 93 p.

OFR 88 量 $\$ 2.00$

A Mechanically Simple and Low Cost Subaqueous Surface Sediment Sampler, by J.H. Balsillie, 2003,9 p.

\section{OFR 91 品 Free}

Text to accompany geologic map of the eastern portion of the U.S.G.S. Perry $30 \times 60$ minute quadrangle, northern Florida (Open-File Map Series 98), by R.C. Green, D.T. Paul, and T.M. Scott, 2007, 32 p.

\section{OFR 92 물}

Text to accompany geologic map of the western portion of the U.S.G.S. Perry $30 \times 60$ minute quadrangle, northern Florida (Open-File Map Series 99), by R.C. Green, D.T. Paul, and T.M. Scott, 2008, 35 p.

\section{OFR 93 Free}

Text to accompany geologic map of the eastern portion of the U.S.G.S. Ocala $30 \times 60$ minute quadrangle, northcentral Florida (Open-File Map Series 100), by R.C. Green, C.P. Williams, D.T. Paul, C. Kromhout, and T.M. Scott, 2009, 28 p.

\section{OFR 94 邑 Free}

Text to accompany geologic map of the western portion of the USGS Ocala $30 \times 60$ minute quadrangle, northcentral Florida (Open-File Map Series 101) by C.P. Williams, R. C. Green, A.D. Flor, D.T. Paul, T.M. Scott, and C. Kromhout, 2010, 29 p.

\section{OFR 95 帛 $\$ 2.00$}

Geology of Washington County, Florida, by F. R. Rupert and G. H. Means, 2009, 16 p.

\section{OFR 96 品 Free}

Text to accompany geologic map of the eastern portion of the U.S.G.S. Inverness $30 \times 60$ minute quadrangle, central Florida (Open-File Map Series 102) by C.P. Williams, K.E. Burdette, R.C. Green, S.W. Bassett, A.D. Flor and D.T. Paul, 2011, 40 p.

\section{OFR 97 Free}

Text to accompany geologic map of the western portion of the U.S.G.S. Inverness 30 x 60 minute quadrangle, central Florida (Open-File Map Series 103), by C.P. Williams and R.C. Green, 2012, 29 p.

\section{OFR 98 吕 Free}

Text to accompany geologic map of the U.S.G.S. Tarpon Springs $30 \times 60$ minute quadrangle, central Florida (Open-File Map Series 104), by R.C. Green, W. L. Evans III, C.P. Williams, C. Kromhout, and S.W. Bassett, 2012, 40 p. 
OFR 99 品 Free

A geophysical delineation of the thickness of unconsolidated sediments on the inner continental shelf offshore of St. Lucie County, Florida, by D.C. Phelps and A.E. Baker, 2015, 8 p.

\section{OFR 100 ㅁeㄹ}

Geochemical and mineralogical study of core samples from W-19318 (USGS G-2984) Broward County, Florida, part of an aquifer storage and recovery feasibility study, by C. Fischler, 2015, $81 \mathrm{p}$.

\section{OFR 101 品 Free}

Text to accompany geologic map of the U.S.G.S. Daytona Beach 30x60 minute quadrangle, northeast Florida (Open-File Map Series 105), by R.C. Green, W.L. Evans III, and S.W. Bassett, 2013, 37p.

\section{OFR 102 Free}

Text to accompany geologic map of the U.S.G.S. Saint Augustine $30 \times 60$ minute quadrangle, northeast Florida (Open-File Map Series 106), by R.C. Green, C.P. Williams, K.M. Campbell, P.W. Bambach, L.M. Hannon, S.W. Bassett, W.L. Evans III, D.T. Paul, and B. Apolinar, 2014, 34 p.

\section{OFR 104 Free}

Text to accompany geologic map of the U.S.G.S. Orlando 30 x 60 minute quadrangle, central Florida (Open-File Map Series 107), by R.C. Green, C.P. Williams, P.W. Bambach, L.M. Hannon, B. Apolinar, K.M. Campbell, and S.B. Dyer, 2015, 37 p.

\section{OFR105品 Free}

Text to accompany geologic map of the U.S.G.S. Jacksonville $30 \times 60$ minute quadrangle, northeast Florida (Open-File Map Series 108), by R.C. Green, C.P. Williams, P.W. Bambach, B. Apolinar, L.M. Hannon, and K.M. White, 2016, 31 p.

\section{OFR 106 回 Free}

Text to accompany geologic map of the USGS Saint Petersburg 30 x 60 minute quadrangle, west-central Florida (Open-File Map Series 109), by R.C. Green, C.P. Williams, B. Apolinar, K.M. White, S.W. Bassett, and L.F. Nason, 2017, 41 p.

\section{OFR 107 말 Free}

Text to accompany geologic map of the USGS Kissimmee 30 x 60 minute quadrangle, central Florida (Oppen-File Map Series 110), by R.C. Green, C.P. Williams, A.G. Lamarche, C.K. Albritton, K.M. White, and S.W. Bassett, 2018, 42 p.

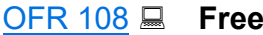

Text to accompany geologic map of the USGS Bartow $30 \times 60$ minute quadrangle central Florida, by R.C. Green, C.P. Williams, A.G. Lamarche, C.L. Hebets, C.K. Albritton, and G.S. Evans, 2019, 38 p.

\section{OFR 109 맬}

Green, R.C., Lamarche, A.G., Williams, C.P., Hebets, C.L., Evans, G.S., and Albritton, C.K., 2021, Text to accompany geologic map of the USGS Vero Beach $30 \times 60$ minute quadrangle central Florida, $33 \mathrm{p}$.

OFR 110 Free

Green, R.C., Williams, C.P., Hebets, C.L., Greene, J.W., Hall, N.P., Evans, G.S., and Duffey, B.M., 2022, Text to accompany geologic map of the USGS Fort Pierce 30 × 60 minute quadrangle south Florida, $32 \mathrm{p}$.

\section{$=$ Available online}




\section{POSTERS}

There will be a minimum charge of $\mathbf{\$ 4 . 0 0}$ per order for the shipping and handling of the free posters. Charges are to cover the survey's cost of mailing tubes and postage. This charge is not per poster, but per order.

POSTER 1 䓛 OUT OF PRINT

Florida Minerals. Nine illustrations of five Florida minerals, by FGS staff. Color, 23.5" x 18".

POSTER 2 薦 OUT OF PRINT

Selected Cenozoic Benthic Foraminifera from Florida, compiled by F. Rupert. 25" x 20".

POSTER 3 OUT OF PRINT

Florida's Fossil Mammals. Illustrates reconstructed skeletons of large Miocene-Pleistocene mammals, with text, by F. Rupert. Black and white, 18.5" x 24".

\section{POSTER 4 OUT OF PRINT}

Common Cenozoic Echinoids from Florida. Illustrates 22 fossil echinoid species, by R. Portell, C. Oyen and F. Rupert. Black and white, 22.5" x 35".

\section{POSTER 5 OUT OF PRINT}

Florida's Hydrogeologic Environment by P. Bond, 1992. Illustrates the hydrogeology of karst terrain, with text. Color, $34 " x$ 22".

\section{POSTER 5 (Revised) 品 Free}

Florida's Hydrogeologic Environment by P. Bond, 2002. Illustrates the hydrogeology of karst terrain, with rev. text and rev. color, 34" x 22".

\section{POSTER 6 맬 $\quad$ Free}

Earth Systems: The Foundation of Florida's Ecosystems, by E. Lane and F. Rupert, 1996. Color, 40" x 60".

\section{POSTER 7 品 FREE}

Geologic History of Florida, by L. Hatchett, 2000. Color, 25" x 37".

\section{POSTER 8 品 Free}

Protecting Florida's Springs by P. Bond, 2002. Same artwork as Poster 5 rev., illustrating the hydrogeology of karst terrain, with different text. Color, 34" x 22".

\section{POSTER 9 䓛 Free}

Florida's Industrial Minerals: Making Modern Life Possible, compiled by S. Spencer and F. Rupert, 2003. Color, 22" x 37".

\section{POSTER 10 물 Free}

Land Use and Spring Protection, by P. Bond, 2003. Color, 23" x 35".

\section{POSTER 11 매료 Free}

Florida's Sinkholes, by F. Rupert and S. Spencer, 2004. Color, 22" x 34".

\section{POSTER 12 品 Free}

Florida's First Magnitude Springsheds, by T. Greenhalgh, 2003. Color, 25" x 37".

\section{POSTER 13 매을 OUT OFINT}

Karst Educational Posters. 8 posters included, by Hazlett-Kincaid, Inc. Color, 2003, CD format only.

\section{POSTER 14 몰 OUT OF PRINT}

Springs of Marion County, Florida, by G.H. Means and D.S. Anderson, 2005. Color, 24" x 36", CD format only. 


\section{REPORTS OF INVESTIGATIONS}

\section{Reports of Investigations (RI) are comprehensive reports on geology and related topics, and are generally narrow in topical scope or in geographic area.}

\section{RI 1 OUT OF PRINT}

Ground Water in Seminole County, Florida, by V.T. Stringfield, 1934, 14 p.

\section{RI 2 OUT OF PRINT}

Ground Water in the Lake Okeechobee Area, Florida, by V.T. Stringfield, 1933, 31 p.

\section{RI 3 OUT OF PRINT}

The Dolomitic Limestones of Florida, by R.H. Hopkins, 1942, 105 p.

\section{RI 4 喝 OUT OF PRINT}

Interim Report on the Investigations of Water Resources in Southeastern Florida with Special Reference to the Miami Area in Dade County, by G.G. Parker, G.E. Ferguson, and S.K. Love, 1944, 39 p., 9 pl.

\section{RI 5 OUT OF PRINT}

Ground Water Conditions in Orlando and Vicinity, by A.G. Unklesbay, 1944, 61 p., 11 fig., 2 tables.

\section{RI 6 OUT OF PRINT}

Geology and Ground Water of the Fort Lauderdale Area, Florida, by R.C. Vorhis, 1948, 32 p., 12 pl.

\section{RI 7 OUT OF PRINT}

Water Resources Studies, 1951, 84 p., 20 fig., 3 tables. (1) Potential Yield of Ground Water of the Fair Point Peninsula, Santa Rosa County, by R.C. Heath and W.E. Clark, 1951, 66 p., 10 fig., 3 tables; (2) Geology and Hydrologic Features of an Artesian Submarine Spring East of Florida, by V.T. Stringfield and G.H. Cooper, Jr., 1951, 16 p., 6 fig.;

(3) Cessation of Flow of Kissengen Spring in Polk County, by G.M. Peek, 1951, 12 p., 5 fig.

\section{RI 8 OUT OF PRINT}

Eleven Archaeological Sites in Hillsborough County, Florida, by R.B. Bullen, 1952, 84 p., frontispiece, 24 fig., 6 tables.

\section{RI 9 品 OUT OF PRINT}

Miscellaneous Studies, 1953. (1) Dissolved Phosphorus in Florida Waters, by H.T. Odum, 40 p., 9 fig., 7 tables;

(2) Petrology of Eocene Limestones In and Around the Citrus-Levy County Area, Florida, by A.G. Fischer, 70 p., 15 fig., 6 tables.

\section{RI 10 OUT OF PRINT}

Ground Water of Central and Northern Florida, by H.H. Cooper, W.E. Kenner and E. Brown, 1953, 37 p., 23 fig.

\section{RI 11 OUT OF PRINT}

Ground-Water Resources of the Naples Area, Collier County, Florida, by H. Klein, 1954, 64 p., 15 fig., 7 tables.

\section{RI 12 믈 OUT OF PRINT}

Ground Water Resources of Pinellas County, Florida, by R.C. Heath and P.C. Smith, 1954, 139 p., 21 fig., 5 tables.

\section{RI 13 믈 OUT OF PRINT}

Water Resources of Palm Beach County, Florida, by M.C. Schroeder, D.L. Milliken, and S.K. Love, 1954, 63 p., 21 fig., 10 tables.

\section{RI 14 OUT OF PRINT}

The Avifauna of the Bone Valley Formation, by P. Brodkorb, 1955, 59 p., 2 pl., 8 tables.

\section{RI 15 OUT OF PRINT}

Geology and Ground-Water Resources of Highlands County, Florida, by E.W. Bishop, 1956, 115 p., 12 fig., 11 tables.

\section{RI 16 ㅁT OF PRINT}

Miscellaneous Studies, 1958. (1) Geology of the Area In and Around the Jim Woodruff Reservoir, by C.W. Hendry, Jr. and J.W. Yon, Jr., 52 p., 8 fig.; (2) Phosphate Concentrations Near Bird Rookeries in South Florida, by E.H. Lund, 16 p., 1 fig., 5 tables; (3) An Analysis of Ochlockonee River Channel Sediments, by E.H. Lund and P.C. Haley, 9 p., 3 tables. 


\section{RI 17 D OUT OF PRINT}

Biscayne Aquifer of Dade and Broward Counties, Florida, by M.C. Schroeder, H. Klein, and N.D. Hoy, 1958, 56 p., 24 fig.

\section{RI 18 믈 OUT OF PRINT}

Ground-Water Resources of Manatee County, Florida, by H.M. Peek, 1958, 99 p., 1 pl., 46 fig., 7 tables.

\section{RI 19 OUT OF PRINT}

Hydrologic Features of the Lake Istokpoga and Lake Placid Areas, Highlands County, Florida, (1) Lake Istokpoga Area, Highlands County, Florida, by F.A. Kohout, 25 p.; (2) Lake Placid Area, Highlands County, Florida, by F.A. Kohout and F.W. Meyer, 1959, 40 p.

\section{RI 20 OUT OF PRINT}

Ground-Water Resources of the Oakland Park Area of Eastern Broward County, Florida, by C.B. Sherwood, 1959, 40 p., 23 fig., 2 tables.

\section{RI 21 OUT OF PRINT}

The Artesian Water of the Ruskin Area of Hillsborough County, Florida, by H.M. Peek, 1959, 96 p., 47 fig., 7 tables.

\section{RI 22 OUT OF PRINT}

The Ground-Water Resources of Volusia County, Florida, by G.G. Wyrick, 1960, 65 p., 30 fig., 3 tables.

\section{RI 23 OUT OF PRINT}

Geology and Ground-Water Resources of Martin County, Florida, by W.F. Lichtler, 1960, 149 p.,

\section{RI 24 OUT OF PRINT}

(1) Hydrologic Conditions in the Vicinity of Levee 30, Northern Dade County, Florida, by H. Klein and C.B. Sherwood, 1961, 24 p., 11 fig.; (2) Hydrologic Studies in the Snapper Creek Canal Area, Dade County, Florida, by C.B. Sherwood and S.D. Leach, 1962, 32 p., 18 fig.; (3) Hydrologic Studies in the Snake Creek Canal Area, Dade County, Florida, by C.B. Sherwood and S.D. Leach, 1963, 33 p., 19 fig.; (4) Salt-Water Movement Caused by Control-Dam Operation in the Snake Creek Canal, Miami, Florida, by F.A. Kohout and S.D. Leach, 1964, 49 p., 22 fig.

\section{RI 25 OUT OF PRINT}

Water Resources of Hillsborough County, Florida, by C.G. Menke, E.W. Meredith, and W.S. Wetterhall, 1961, 101 p., 52 fig., 6 tables.

\section{RI 26 OUT OF PRINT}

The Drought of 1954-56, Its Effect on Florida's Surface-Water Resources, by R.W. Pride and J.W. Crooks, 1962, 65 p., 9 fig., 5 tables.

\section{RI 27 OUT OF PRINT}

Ground-Water Resources of Seminole County, Florida, by J.T. Barraclough, 1962, 91 p., 45 fig., 7 tables.

\section{RI 28 OUT OF PRINT}

Water Resources of Brevard County, Florida, by D.W. Brown, W.E. Kenner, J.W. Crooks, and J.B. Foster, 1962, 104 p., 45 fig., 10 tables.

\section{RI 29 OUT OF PRINT}

Aquifers and Quality of Ground Water Along the Gulf Coast of Western Florida, by J.T. Barraclough and O.T. Marsh, 1962, 28 p., 12 fig.

\section{RI 30 OUT OF PRINT}

Reconnaissance of the Geology and Ground-Water Resources of Columbia County, Florida, by F.W. Meyer, 1962, 73 p., 19 fig., 8 tables.

\section{RI 31 OUT OF PRINT}

Ground-Water Resources of Collier County, Florida, by H.J. McCoy, 1962, 82 p., 29 fig., 5 tables.

\section{RI 32 OUT OF PRINT}

Geology and Ground-Water Resources of Flagler, Putnam, and St. Johns Counties, Florida, by B.J. Bermes, G.W. Leve, and G.R. Tarver, 1963, 97 p., 38 fig., 7 tables. 


\section{RI 33 OUT OF PRINT}

Hydrology of Brooklyn Lake Near Keystone Heights, Florida, by W.E. Clark, R.H. Musgrove, C.G. Menke, and J.W. Cagle, Jr., 1963, 43 p., 26 fig., 2 tables.

\section{RI 34 OUT OF PRINT}

Geohydrologic Reconnaissance of Pasco and Southern Hernando Counties, Florida, by W.S. Wetterhall, 1964,28 p., 7 fig., 5 tables.

\section{RI 35 OUT OF PRINT}

Water Resources of Alachua, Bradford, Clay, and Union Counties, Florida, by W.E. Clark, R.H. Musgrove, C.G. Menke and J.W. Cagle, Jr., 1964, 170 p., 92 fig., 14 tables.

\section{RI 36 OUT OF PRINT}

Hydrology of the Biscayne Aquifer in the Pompano Beach Area, Broward County, Florida, by G.R. Tarver, 1964, 47 p., 24 fig., 4 tables.

\section{RI 37 OUT OF PRINT}

Geology and Ground-Water Resources of Glades and Hendry Counties, Florida, by H. Klein, M.C. Schroeder, and W.F. Lichtler, 1964, 101 p., 33 fig., 8 tables.

\section{RI 38 OUT OF PRINT}

Possibility of Salt-Water Leakage from Proposed Intracoastal Waterway Near Venice, Florida Well Field, by W.E. Clark, 1964, 33 p., 11 fig., 3 tables.

\section{RI 39 OUT OF PRINT}

Reconnaissance of Springs and Sinks in West-Central Florida, by W.S. Wetterhall, 1965, 42 p., 5 fig.

\section{$\underline{\mathrm{RI}} 40$ 点 OUT OF PRINT}

Water Resources of Escambia and Santa Rosa Counties, Florida, by R.H. Musgrove, J.T. Barraclough, and R.G. Grantham, 1965, 102 p., 46 fig., 1 table.

\section{RI 41 点 OUT OF PRINT}

Water Resources of the Econfina Creek Basin Area in Northwestern Florida, by R.H. Musgrove, J.B. Foster, and L.G. Toler, 1965, 51 p., 28 fig, 2 tables.

\section{RI 42 回 OUT OF PRINT}

Hydrology of Green Swamp Area in Central Florida, by R.W. Pride, F.W. Meyer, and R.N. Cherry, 1966, 137 p., 58 fig., 18 tables.

\section{RI 43 OUT OF PRINT}

Ground Water in Duval and Nassau Counties, Florida, by F.W. Leve, 1966, 91 p., 22 fig., 8 tables.

\section{RI 44 回 OUT OF PRINT}

Ground-Water Resources of Polk County, by H.G. Stewart, Jr., 1966, 170 p., 36 fig., 14 tables.

\section{RI 45 回 OUT OF PRINT}

Salt-Water Study of the Miami River and Its Tributaries, Dade County, Florida, by S.D. Leach and R.G. Grantham, 1966, 36 p., 21 fig.

\section{RI 46 点 OUT OF PRINT}

Fluoride in Water in the Alafia and Peace River Basins, Florida, by L.G. Toler, 1967, 46 p., 20 fig., 2 tables.

\section{$\underline{\mathrm{RI}} 47$ OUT OF PRINT}

Hydrologic Effects of Area B Flood Control Plan on Urbanization of Dade County, Florida, by F.A. Kohout and J.H. Hartwell, 1967, 61 p., 24 fig., 7 tables.

\section{RI 48 回 OUT OF PRINT}

Analysis of the Water-Level Fluctuations of Lake Jackson Near Tallahassee, Florida, by G.H. Hughes, 1967,25 p., 16 fig., frontispiece, 2 tables.

\section{$\underline{\mathrm{RI}} 49$ OUT OF PRINT}

Hydrologic Effects of Ground-Water Pumpage in the Peace and Alafia River Basins, Florida, 1934-1965, by M.I. Kaufman, 1967, 32 p., 10 fig., 14 tables. 


\section{$\underline{\mathrm{RI}} 50$ 品 OUT OF PRINT}

Water Resources of Orange County, Florida, by W.F. Lichtler, W. Anderson, and B.F. Joyner, 1968,150 p., 62 fig., 14 tables.

\section{RI 51 OUT OF PRINT}

Chemical Quality of Waters of Broward County, Florida, by R.G. Grantham and C.B. Sherwood, 1968, 52 p., 16 fig., 3 tables.

\section{RI 52 OUT OF PRINT}

Reconnaissance of the Ground-Water Resources of Baker County, Florida, by G.W. Leve, 1968, 24 p., 9 fig., 3 tables.

\section{RI 53 OUT OF PRINT}

Low Streamflow in the Myakka River Basin Area in Florida, by G.N. Flippo, Jr. and B.F. Joyner, 1968,34 p., 5 fig., 6 tables.

\section{RI 54 OUT OF PRINT}

Water Resources of Northeast Florida (St. Johns River Basin and Adjacent Coastal Areas), by L.J. Snell and W. Anderson, 1970, 77 p., 34 fig., 9 tables.

\section{$\underline{\mathrm{RI}} 55$ OUT OF PRINT}

Ground-Water Resources of the Lower Hillsboro Canal Area, Southeastern Florida, by H.J. McCoy and J. Hardee, 1970, 44 p., 21 fig., 3 tables.

\section{RI 56 OUT OF PRINT}

General Hydrology of the Middle Gulf Area, Florida, by R.N. Cherry, J.W. Stewart, and J.A. Mann, 1970,96 p., 45 fig., 4 tables.

\section{RI 57 嵒 OUT OF PRINT}

Evaluation of Quantity and Quality of the Water Resources of Volusia County, Florida, by D.D. Knochenmus and M.E. Beard, 1971, 59 p., 22 fig., 8 tables.

\section{RI 58 点 OUT OF PRINT}

Seepage Beneath Hoover Dike, Southern Shore of Lake Okeechobee, Florida, by F.W. Meyer, 1971,98 p., 41 fig., 9 tables.

\section{RI 59 回 OUT OF PRINT}

The Shallow-Aquifer System in Duval County, Florida, by R.W. Fairchild, 1972, 50 p., 15 fig., 10 tables.

\section{RI 60 OUT OF PRINT}

Hydrologic Effects of Water Control and Management of Southeastern Florida, by S.D. Leach, H. Klein, and E.R. Hampton, 1972, 115 p., 47 fig., 12 tables.

\section{RI 61 OUT OF PRINT}

Appraisal of Water Resources in the East Central Florida Region, by W.F. Lichtler, 1972, 52 p., 11 fig., 7 tables.

\section{RI 62 OUT OF PRINT}

Water Available in Canals and Shallow Sediments in St. Lucie County, Florida, by H.W. Bearden, 1972,50 p., 23 fig., 4 tables.

\section{RI 63 매요 OUT OF PRINT}

Hydrology of Western Collier County, Florida, by J. McCoy, 1972, 32 p., 11 fig., 3 tables.

\section{RI 64 OUT OF PRINT}

Hydrologic Conditions in the Lakeland Ridge Area of Polk County, Florida, by A.F. Robertson, 1973, 54 p., 23 fig., 6 tables.

\section{RI 65 点 OUT OF PRINT}

Water Resources of Broward County, Florida, by C.B. Sherwood, H.J. McCoy and C.F. Galliher, 1973,141 p., 64 fig., 7 tables. 


\section{RI 66 OUT OF PRINT}

Salinity Studies in East Glades Agricultural Area, Southeastern Dade County, Florida, by J.E. Hull and F.W. Meyer, 1973, 20 fig., 2 tables.

\section{RI 67 OUT OF PRINT}

Appraisal of the Water Resources of Eastern Palm Beach County, Florida, by L.F. Land, H. G. Rodis and J.J. Schneider, 1973, 40 fig., 5 tables.

\section{RI 68 OUT OF PRINT}

Hydrogeologic Aspects of a Proposed Sanitary Landfill near Old Tampa Bay, Florida, by R.N. Cherry and D.P. Brown, 1974, 8 fig., 3 tables.

\section{RI 69 OUT OF PRINT}

The Shallow Fresh-Water System of Sanibel Island, Lee County, Florida, with Emphasis on the Sources and Effects of Saline Water, by D.H. Boggess, 1974, 52 p., 23 fig., 2 tables.

\section{RI 70 品 OUT OF PRINT}

Indicators of Organic Contamination in Plantation Canal, Broward County, Florida, 1971-72, by T.N. Russo, 1974,38 p., 18 fig., 8 tables.

\section{RI 71 OUT OF PRINT}

Chemical and Biological Conditions of Lake Okeechobee, Florida, 1969-72, by B.F. Joyner, 1974, 94 p., 8 fig., 19 tables.

\section{RI 72 OUT OF PRINT}

Hydrologic Concepts of Artificially Recharging the Floridan Aquifer in Eastern Orange County, Florida - A Feasibility Study, by D.D. Knochenmus, 1975, 14 fig., 2 tables.

\section{RI 73 昜 OUT OF PRINT}

Water Balance of Lake Kerr - A Deductive Study of a Landlocked Lake in North-Central Florida, by G.H. Hughes, 1974, 49 p., 18 fig., 6 tables.

\section{RI 74 回 OUT OF PRINT}

Hydrologic Consequences of Using Ground Water to Maintain Lake Levels Affected by Water Wells Near Tampa, Florida, by J.W. Stewart and G.H. Hughes, 1974, 41 p., 20 fig., 2 tables.

\section{RI 75 回 OUT OF PRINT}

Evaluation of Hydraulic Characteristics of a Deep Artesian Aquifer from Natural Water-Level Fluctuations, Miami, Florida, by F.W. Meyer, 1974, 32 p., 9 fig., 2 tables.

\section{$\underline{\text { RI } 76}$ 品 OUT OF PRINT}

Water Resources of Walton County, Florida, by C.A. Pascale, 1974, 65 p., 28 fig., 8 tables.

\section{$\underline{\mathrm{RI}} 77$ OUT OF PRINT}

Ground-Water Resources of the Hollywood Area, Florida, by H.W. Bearden, 1974, 35 p., 17 fig., 3 tables.

\section{$\underline{\mathrm{RI}} 78$ 品 OUT OF PRINT}

Appraisal of the Water Resources of Charlotte County, Florida, by H. Sutcliffe, Jr., 1975, 53 p., 18 fig., 13 tables.

\section{RI 79 OUT OF PRINT}

Summary of Hydrologic Conditions and Effects of Walt Disney World Development in the Reedy Creek Improvement District, 1966-73, by A.L. Putnam, 1975, 115 p., 30 fig., 13 tables.

\section{RI 80 OUT OF PRINT}

Water Resources of Indian River County, Florida, by L.J. Crain, G.H. Hughes, and L.J. Snell, 1975,75 p., 38 fig., 4 tables.

\section{RI 81 OUT OF PRINT}

Hydrology of Three Sinkhole Basins in Southwestern Seminole County, Florida, by W. Anderson and G.H. Hughes, 1975, 35 p., 15 fig.

\section{$\underline{\mathrm{RI}} 82$ OUT OF PRINT}

Hydrologic Effects of the Tampa Bypass Canal System, by L.H. Motz, 1975, 42 p., 22 fig., 4 tables. 


\section{RI 83 OUT OF PRINT}

Ground-Water Resources of DeSoto and Hardee Counties, Florida, by W. E. Wilson, 1977, 102 p., 1 pl., 42 fig., 10 tables.

\section{RI 84 OUT OF PRINT}

The Highland Heavy-Mineral Sand Deposit on Trail Ridge in Northern Peninsular Florida, by E.C. Pirkle, W.A. Pirkle, and W.H. Yoho, 1977, 50 p., 5 fig., 12 tables.

\section{$\underline{\text { RI } 85}$ OUT OF PRINT}

The Geology of the Western Part of Alachua County, Florida, by K.E. Williams, D. Nicol, and A.F. Randazzo, 1977, 98 p., 22 fig.

\section{RI 86 OUT OF PRINT}

Regional Structure and Stratigraphy of the Limestone Outcrop Belt in the Florida Panhandle, by W. Schmidt and C. Coe, 1978, 25 p., 15 fig.

\section{RI 87 OUT OF PRINT}

The Geology and Water Resources of the Upper Suwannee River Basin, Florida, by R. Ceryak, M.S. Knapp, and T. Burnson, 1983, 165 p., 58 fig., 3 tables.

\section{RI 88 OUT OF PRINT}

The Limestone, Dolomite and Coquina Resources of Florida, by W. Schmidt, R.W. Hoenstine, M.S. Knapp, E. Lane, G.M. Ogden, Jr., and T.M. Scott 1979, 64 p., 13 fig., 5 maps.

\section{RI 89 品 OUT OF PRINT}

Stratigraphy and Oil Potential of the Lower Cretaceous Sunniland Formation in South Florida, by A.V. Applegate and F.A. Pontigo, Jr., 1984, 40 p., 20 fig., 3 tables.

\section{RI 90 嵒 OUT OF PRINT}

The Sand and Gravel Resources of Florida, by T.M. Scott, R.W. Hoenstine, M.S. Knapp, E. Lane, G.M. Ogden, Jr., R. Deuerling, and H.E. Neel, 1980, 41 p., 6 fig., 4 tables.

\section{RI 91 OUT OF PRINT}

The Hawthorn Formation of Central Florida: (1) Geology of the Hawthorn Formation in Central Florida, by T.M. Scott and P.L. MacGill; (2) Characterization, Evaluation, and Beneficiation of Central Florida Phosphate-Bearing Hawthorn Formation, by W.H. Eddy, B.E. Davis, and G.V. Sullivan, 1981, 107 p., 10 fig., 12 tables.

\section{RI 92 OUT OF PRINT}

Shallow Stratigraphy of Okaloosa County and Vicinity, Florida, by M.W. Clark and W. Schmidt, 1982,28 p., 19 fig.

\section{RI 93 OUT OF PRINT}

Biostratigraphy of Selected Cores of the Hawthorn Formation in Northeast and East-Central Florida, by

R.W. Hoenstine, 1984, 68 p., 16 fig., 1 table, 13 pl.

\section{RI 94 OUT OF PRINT}

The Hawthorn Formation of Northeastern Florida: (1) The Geology of the Hawthorn Formation of Northeastern Florida, by T.M. Scott; (2) Characterization and Beneficiation of the Northeastern Florida Phosphate-Bearing Hawthorn Formation, by B.E. Davis, G.V. Sullivan, and T.O. Llewellyn, 1983, 90 p., 17 fig., 5 tables (Updates Open File Report 1).

\section{RI 95 OUT OF PRINT}

Heavy Mineral Reconnaissance Off the Coast of the Apalachicola River Delta, Northwest Florida, by J.D. Arthur, J. Applegate, S. Melkote, and T.M. Scott, 1986, 61 p., 24 fig., 2 tables.

\section{RI 96 圆 OUT OF PRINT}

An Investigation of the Geology, Hydrogeology, and Hydrochemistry of the Lower Suwannee River Basin, by J.J. Crane, 1986, 205 p., 74 fig., 14 tables.

\section{RI 97 OUT OF PRINT}

Petrogenesis of Early Mesozoic Tholeiite in the Florida Basement and An Overview of Florida Basement Geology, by J.D. Arthur, 1988, 39 p., 12 fig., 7 tables.

\section{RI 98 OUT OF PRINT}

Geology of Sumter County, Florida, by K.M. Campbell, 1989, 28 p., 17 fig. (Updates Open File Report 7) . 


\section{$\underline{\mathrm{RI}} 99$ 品 OUT OF PRINT}

Reappraisal of the Geology and Hydrogeology of Gilchrist County, Florida, with Emphasis on the Wacassassa Flats, by N. Col, F. Rupert, M. Enright, and G. Horvath, 1997, 76 p.

\section{RI 100 品 OUT OF PRINT}

Florida Aquifer Storage and Recovery Geochemical Study, southwest Florida: Year One \& Year Two Progress Report, by H. Williams, J. B. Cowart and J. D. Arthur, 2002, 131 p.

\section{RI 101 OUT OF PRINT}

A Geological Investigation of Sand Resources in the Offshore Area Along Florida's Central-East Coast, by R. Hoenstine, H. Freedenberg, A. Dabous, B. Cross, C. Fischler, and M. Lachance, 2002, 14 p.

\section{RI 103 매요 $\$ 4.00$}

High Resolution Sea-Level History for the Gulf of Mexico Since the Last Glacial Maximum, by J.H. Balsillie and J.F. Donoghue, 2004, 65 p.

\section{$\underline{\mathrm{RI} 104}$ 邑 $\$ 4.00$}

Wekiva Aquifer Vulnerability Assessment, by J.R. Cichon, A.E. Baker, A.R. Wood, and J.D. Arthur, 2005,36 p.

\section{RI 107 邑 $\$ 4.00$}

A Sedimentological Analysis of Sea grass Bed Substrate from Bay County, Florida, by D.C. Phelps, M.M. Lachance, and J.G. Sparr, 2007. CD format only.

\section{RI 111 䓛 Free}

Demonstrating interconnection between a wastewater application facility and a first magnitude spring in a karstic watershed: Tracer study of the Southeast Farm Wastewater Reuse Facility, Tallahassee, Florida, by T.R. Kincaid, G.J. Davies, C. Werner, and R.S. DeHan, 2012, 192 p.

\section{RI 112 Free}

A review of selected Florida Aquifer Storage and Recovery (ASR) sites and their geochemical characteristics, by C. Fischler, P. Hansard, M. Ladle, and C. Burdette, 2015, 216 p.

\section{RI 113 䓛 Free}

Geochemical, Mineralogical and Petrographic Characterization of Rocks Comprising the Upper Floridan Aquifer System in South Florida, by C. Fischler and J.D. Arthur, 2014, 137p.

\section{RI 115 Free}

A petrographic, mineralogical and geochemical study of core samples from Paradise Run aquifer storage and recovery well (HIF-42) and Brighton Reservation aquifer storage and recovery exploratory well (BREX-1), by C. Fischler, 2015, $211 \mathrm{p}$.

\section{RI 121 品 Free}

The bathymetry, top of rock, and thickness of unconsolidated sediments offshore of the northeast and central east coast of Florida, by D.C. Phelps, S.W. Bassett, and A.E. Baker, 2017, 21 p.

\section{RI 122 品 Free}

Ground-penetrating radar survey of Ichetucknee Springs State Park south entrance parking lot and picnic area, by C. Albritton and T. Barnett, 2022, 17 p. 


\section{SPECIAL PUBLICATIONS}

Special Publications (SP) contain geologic and related information of significant interest to the scientific community and the general public. They may include topical compilations from conferences or symposiums.

\section{SP 1 OUT OF PRINT}

A Provisional Gazeteer of Florida Place-Names of Indian Derivation Either Obsolescent or Retained Together with Others of Recent Application, by J.C. Simpson, 1956, 158 p., 5 maps.

\section{SP 2 OUT OF PRINT}

Contributions to Florida Vertebrate Paleontology: (1) A New Species of Osteoborus From the Bone Valley Formation of Florida, by S. J. Olsen, 1956, 5 p.; (2) The Skull of Leptarctus ancipidens From the Florida Miocene, by S.J. Olsen, 1958, 11 p.; (3) Description of a Beryciform Fish from the Oligocene of Florida, by D.H. Dunkle, and S.J. Olsen, 1959, 20 p.; (4) Fossil Birds From Alachua Clay of Florida, by P. Brodkorb,1963, 17 p.

\section{SP 3 믈 OUT OF PRINT}

A List, Bibliography, and Index of the Fossil Vertebrates of Florida, by C.E. Ray, 1957, 175 p.

\section{SP 4 OUT OF PRINT}

Bibliography and Index of Articles Relating to the Ground-Water Resources of Florida, 1861-1955, by A.B. Unklesbay, R.C. Heath, and H.M. Peek, 1959, 104 p.

\section{SP 5 品 OUT OF PRINT}

Summary of the Geology of Florida and a Guidebook to the Classic Exposures, by H.S. Puri and R.O. Vernon, 1959, 255 p., 11 fig., 11 pl., 4 tables.

\section{SP 5 (Revised) 믈 OUT OF PRINT}

Summary of the Geology of Florida and a Guidebook to the Classic Exposures, by H.S. Puri and R.O. Vernon, Revised 1964, 312 p., 37 fig., 11 pl., 4 tables.

\section{SP 6 OUT OF PRINT}

Fossil Mammals of Florida, by S.J. Olsen, 1959, 74 p., 13 fig., 14 pl.

\section{SP 7 OUT OF PRINT}

An Investigation of the Darby and Hornsby Springs Sites, Alachua County, Florida, by E.M. Dolan and F.T. Allen, Jr., 1961, 124 p., 10 fig., 16 pl., 1 table.

\section{SP 8 品 OUT OF PRINT}

Rocks and Minerals of Florida, A Guide to Identification, Occurrence, Production and Use, by E.W. Bishop and L.L. Dee, Jr., 1961, 40 p., 25 fig., 1 map.

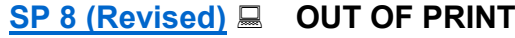

Guide to Rocks and Minerals of Florida, by E. Lane, (revised) 1987, 61 p., 23 fig., 13 maps.

\section{$\underline{\text { SP } 9} \square$ OUT OF PRINT}

Florida Petroleum Exploration, Production and Prospects, by C. Babcock, 1962, 79 p., 7 fig., 9 tables.

\section{SP 10 OUT OF PRINT}

Fossil Vertebrates of Vero, Florida, by R.D. Weigel, 1962, 58 p., 6 fig., 5 tables.

\section{SP 11 OUT OF PRINT}

Index to Water Resources Data-Collection Stations in Florida, 1961, prepared by the U.S. Geological Survey in cooperation with the Florida Geological Survey, 1964, 168 p., 3 fig., 2 tables.

\section{SP 12 品 OUT OF PRINT}

Vertebrate Fossil Localities in Florida, by S.J. Olsen, 1965, 28 p., 11 fig.

\section{SP 13 品 OUT OF PRINT}

The Water Mapping, Monitoring, and Research Program in Florida, by C.S. Conover, K.A. MacKichan, and R.W. Pride, 1965, 41 p., 14 fig., 2 tables.

\section{SP 14 OUT OF PRINT}

Adventures in Geology at Jackson Bluff, by J.W. Yon, Jr., 1965, 14 p., 7 fig. 


\section{SP 15 品 OUT OF PRINT}

The Dollar Bay Formation of Lower Cretaceous (Fredericksburg) Age in South Florida, Its Stratigraphy and

Petroleum Possibilities, by G.O. Winston, 1971, 99 p., 14 fig., 20 tables.

\section{SP 16 믐 OUT OF PRINT}

Environmental Geology and Hydrology, Tallahassee Area, Florida, prepared by the Bureau of Geology, 1972,61 p.

\section{SP 17 믈 OUT OF PRINT}

Proceedings, Seventh Forum on Geology of Industrial Minerals, April 28-30, 1971, H.S. Puri, editor, 1972,228 p.

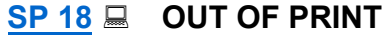

Availability and Potential Utilization of Byproduct Gypsum in Florida Phosphate Operations, by J.W. Sweeney and B.J. Timmons, 1973, 9 p., 4 fig., 2 tables.

\section{SP 19 머 OUT OF PRINT}

Environmental Geology and Hydrology, Tampa Area, Florida, by A.P. Wright, 1974, 94 p.

\section{SP 20 OUT OF PRINT}

Geologic Framework of the High Transmissivity Zones in South Florida, by H.S. Puri and G.O. Winston, 1974, 101 p.

\section{SP 21 믐 OUT OF PRINT}

The Geothermal Nature of the Floridan Plateau, D.L. Smith and G.M. Griffin, editors, 1977, 161 p., 34 fig., 12 tables.

\section{SP 22 OUT OF PRINT}

Florida: The New Uranium Producer, by J.W. Sweeney and S.R. Windham, 1979, 13 p., 2 fig., 3 tables.

\section{SP 23 OUT OF PRINT}

Guidelines for Authors with Comments for Editorial Reviewers, by E. Lane, 1980, 47 p., 8 fig., 2 tables. Updated by Open File Report 53.

\section{SP 24 OUT OF PRINT}

Catalogue of Type Invertebrate Fossils at the Bureau of Geology, by G. Shaak, 1980, 32 p.

\section{SP 25 믈 OUT OF PRINT}

Miocene of the Southeastern United States, Proceedings of a Symposium Held December 4-5, 1980, Tallahassee, Florida, T.M. Scott and S.B. Upchurch, eds., 1982, 319 p., 102 fig., 9 plates.

\section{SP 26 OUT OF PRINT}

The Florida Bureau of Geology, Past, Present, and Future, by R.W. Hoenstine and S. Weissinger, 1983, 49 p., 8 fig., 4 tables.

\section{SP 27 OUT OF PRINT}

An Overview of Peat in Florida and Related Issues, by P. Bond, K.M. Campbell, and T.M. Scott, 1986, 151 p., 28 fig., 9 tables. (Updates Open File Report 4).

\section{SP 28 믈 OUT OF PRINT}

Hydrogeological Units of Florida, compiled by SEGS Ad Hoc Committee, 1986, 8 p., 1 table. (Photocopy).

\section{SP 29 믐 OUT OF PRINT}

Karst in Florida, by E. Lane, 1986, 100 p., 59 fig., 4 tables. (Photocopy).

\section{SP 30 OUT OF PRINT}

Geologic Descriptions of Selected Exposures in Florida, by R.A. Johnson, 1989, 175 p.

\section{SP 31 믄 OUT OF PRINT}

Environmental Geology and Hydrogeology of the Ocala Area, Florida, by E. Lane and R.W. Hoenstine, 1990, 71 p.

\section{SP 32 믄 OUT PRINT}

Florida's Ground Water Quality Monitoring Program, Hydrogeological Framework, edited by T.M. Scott, J.M. Lloyd, and G.L. Maddox, 1991, 97 p., 77 fig., 2 tables.

\section{SP 33 D OUT OF PRINT}

Environmental Geology and Hydrogeology of the Gainesville Area, Florida, by R.W. Hoenstine and E. Lane, 1991, 70 p., 41 fig., 8 tables. 


\section{SP 34 OUT OF PRINT}

Florida's Ground Water Quality Monitoring Program, Background Hydrogeochemistry, edited by G.L. Maddox, J.M. Lloyd, T.M. Scott, S.B. Upchurch, and R. Copeland, 1993, 364 p.

\section{SP 35 品 $\$ 4.00$}

Florida's Geological History and Geological Resources, edited by E. Lane, 1994, 76 p.

\section{SP 36 OUT OF PRINT}

Plio-Pleistocene Stratigraphy and Paleontology of Southern Florida, edited by T.M. Scott and W.D. Allmon, 1992, 194 p.

\section{SP 37 OUT OF PRINT}

The Neogene of Florida and Adjacent Regions: Proceedings of the Third Bald Head Island Conference on Coastal Plains Geology, edited by V. Zullo, W.B. Harris, T.M. Scott, and R.W. Portell, 1993, 112 p.

\section{SP 39 믐 OUT OF PRINT}

Bibliography and Index of Graduate Theses and Dissertations on Florida Geology Through 1991 Including Selected Abstracts, compiled by A.N. Jordan and D.E. Mekeel, 1995, 298 p. (Updates Open File Report 2)

\section{SP 40 믈 OUT OF PRINT}

William F. Tanner on Environmental Clastic Granulometry, compiled by J.H. Balsillie, Chief editor: W.F. Tanner, $1995,142 \mathrm{p}$.

\section{SP 41 믈 $\$ 4.00$}

Shore-Breaking Wave Height Transformation, by J.H. Balsillie, and Wavelength and Wave Celerity During ShoreBreaking, by J.H. Balsillie, 2000, 40 p.

\section{SP 42 물 $\quad \$ 4.00$}

The Florida Geological Survey: An Illustrated Chronicle and Brief History, by E. Lane, 1998, 70 p.

\section{SP 43 品 $\$ 4.00$}

Seasonal Variation in Sandy Beach Shoreline Position and Beach Width, by J.H. Balsillie, and Open-Ocean Water Level Datum Planes: Use and Misuse in Coastal Applications, by J.H. Balsillie, 1999, 60 p.

\section{SP 44 呢 $\$ 4.00$}

Geological Assessment: The Foundation of Understanding the "Bucket" that Contains Our Precious Water Resources, by W. Schmidt and T.M. Scott, 1999, 42 p.

\section{SP 45 品 $\$ 4.00$}

On the Breaking of Nearshore Waves, by J.H. Balsillie, and Shore-Breaking Wave Energetics, by J.H. Balsillie, 1999, $183 \mathrm{p}$.

\section{SP 46 鸮 $\$ 4.00$}

The Wakulla Springs Woodville Karst Plain Symposium Transactions, October 9, 1998, compiled by W. Schmidt, J.M. Lloyd, and C. Collier, 2000, 179 p.,

\section{SP 47 鸮 $\quad \$ 4.00$}

Spring Creek Submarine Springs Group, Wakulla County, Florida, by Ed Lane, 2001, 34 p.

\section{SP 48 品 $\$ 4.00$}

Annotated and Illustrated Bibliography of Marine Subaqueous Sand Resources of Florida's Gulf of Mexico, 1942 -1997 , by J.G. Balsillie and R. R. Clark, 2001, 253 p.

\section{SP 49 물 $\$ 4.00$}

Geology and Hydrology of Lee County, Florida, ed. By T.M. Missimer and T.M. Scott, 2001, 230 p.

\section{SP 50 品 $\$ 4.00$}

Guidebook to the Correlation of Geophysical Well Logs within the St. Johns River Water Management District, by J. Davis, R. Johnson, D. Boniol and F. Rupert, 2001, 114 p. 


\section{SP 51 葛 $\$ 5.00$}

Workshop to Develop Blue Prints for the Management and Protection of Florida's Springs - Proceedings, compiled by R. DeHan, Ocala, FI., May 8-9, 2002. CD format only.

\section{SP 52 品 $\$ 4.00$}

Florida Spring Classification System and Spring Glossary, compiled by R. Copeland, 2003, 17 p. Also see insert with corrections and additions.

\section{SP 53 邑 $\$ 5.00$}

Significance of Caves in Watershed Management and Protection in Florida - Workshop Proceedings, April 16-17, 2003, Ocala, FL, compiled by R. DeHan. CD format only.

\section{SP 54 品 $\$ 5.00$}

Aquifer Storage Recovery IV: Science, Technology, Management and Policy - Proceedings, Tampa, FL, April 1516, 2004, CD format only.

\section{SP 56 鸮 $\$ 5.00$}

Wakulla Springs Scientific Symposium, May 13, 2004, Tallahassee, FL. Hosted by Florida Geological Survey and co-sponsored by Springs Initiative of DEP. CD format only.

\section{SP 57 局 OUT OF PRINT}

Geological and Geotechnical Investigation Procedures for Evaluation of the Causes of Subsidence Damage in Florida, compiled by Walt Schmidt, 2005, Online only.

\section{SP 58 品 $\$ 5.00$}

4th Annual Hydrogeology Consortium Workshop: Solving Water Pollution Problems in the Wakulla Springshed of North Florida, May 11-13, 2005, Tallahassee, FL. CD format only.

\section{SP 59 品 FREE AND ONLINE ONLY}

Florida Geomorphology Atlas, by Christopher P. Williams, Thomas M. Scott, and Sam B. Upchurch, 2022. Website only, with downloadable data and PDFs of the text.

\section{$=$ Available online}




\section{VIDEO SERIES}

Florida geoscience education and outreach series.

VS 1 回 $\$ 10.00$

Florida's Geology Unearthed Video Kit, includes DVD or VHS format, color, 60 mins., Educator's Guide, additional resource materials. 1996.

vs 2 足 $\$ 10.00$

Florida's Aquifer Adventure. Color, DVD or VHS format, 20 mins., 2004.

\section{HOW TO OBTAIN A COPY FOR EDUCATIONAL INSTITUTION LIBRARIES}

Publications Office. Please send written request, on institution letterhead, to place a copy of the Video Series in your school library for all teachers to use. 


\begin{tabular}{|ll|}
\hline \multicolumn{2}{|c|}{ KEY TO ABBREVIATIONS } \\
AR & Annual Report \\
B & Bulletin \\
BR & Biennial Report \\
IC & Information Circular \\
L & Leaflet \\
MS & Map Series \\
OFMS & Open File Map Series \\
OFR & Open File Report \\
RI & Report of Investigation \\
SP & Special Report \\
VS & Video Series \\
\hline
\end{tabular}

A

Adams, J.K. SP 17

Aggregates [See: Sand and gravel]

Alachua Clays AR 6(3); SP 2(4)

Alachua County

Geology MS 79; OFMS 12; OFR 21,29,

41; RI 85; SP 33

Geomorphology AR 3; SP 33

Mineral resources IC 46; MS 131

Paleontology B 10; SP 2,7

Water resources IC 36,43; OFR 21,29;

RI 35; SP 7,33

Alafia River Basin MS 67; RI 46,49

Alaqua Creek Valley B 12

Albritton, C.K. MS 158,159,160; OFMS

110,111,112; OFR 107,108,109; RI 122

Allen, G.T., Jr. SP 7

Allison, D. OFMS 84; OFR 54

Allmon, W.D. SP 36

Alum Bluff OFR 9

Alum Bluff Group B 14

Anclote River MS 61

Anders, R.B. IC 6

Anderson, W. IC 41,47,82; L 8;

MS 24,43,43(rev.),55; RI 50,54,81

Andrews, W.J. MS 132

Apalachicola Embayment B 58

Apalachicola River AR 10/11(1), 10/11(3)

Apalachicola River Delta RI 95

Apolinar, B. OFMS 106,107,108,109;

OFR 102,104,105,106

Applegate, A. IC 101,104; RI 89

Applegate, J. RI 95

Aquifer storage and recovery (ASR)

OFR 83; RI 100; SP 54

Aquifers B 70; IC 33,86; MS 16,53;

OFR 54,56,81; SP 28,44,54

Archaeological sites RI 8

Armbruster, J.T. MS 50

Armstrong, C.J. IC 87

Artesian [See also: aquifers;

groundwater; water supply] AR 3(3),

5(3),23/24(6); IC 4,10,21,33,48,52,61,68,

73,75,85; MS 4,56,73; RI 7,21,75

Arthur, J.D. B 68; MS 146, 150; OFMS

$42,44,45,52,57,58,86,88$; OFR 24,34 ,

$46,61,81,83$ RI 95,97,100,104; SP 54
Atlantic coast OFR 35,39,69

Aucilla River AR 9(3)

Avifauna [See: Birds]

B

Babcock, C. IC 42,45,49,54,55,60,63,65, 71,$80 ;$ SP 9,16

Back, W. SP 17

Baker, A.E. OFMS 95; OFR 99; RI 104,121

Baker County

Geology MS 88; OFMS 38; OFR 33

Geomorphology OFR 33

Water resources IC 20; OFR 33; RI 52,87

Bald Head Island Conference SP 37

Ball, M.M. MS 41,57

Balsillie, J.H. BR 22; OFR 73,78,79,87,88;

RI 103; SP 40,41,43,45, 48

Bambach, P.W. OFMS 106,107,108;

OFR 102,104,105

Banks, J.E. SP 21(2)

Barnett, T. RI 122

Barr, G.L. MS 119,138

Barraclough, J.T. IC 5,30,34,50; L 3; MS 26; RI 27,29,40

Basement geology B 55; IC 98; RI 97

Bassett, S.W. OFMS 102,103,104,105,

106,109,110; OFR 96,98,101,102,106,

107; RI 121

Bates, R.L. SP 17

Bay County

Geology B 57,58; L 13; MS 90; OFMS 19

Mineral resources SP 48

Water resources IC 57; MS 10,38,46; RI 41

Beaches AR 19(3), 21/22(4); B 7; OFR 78; RI 101; SP 41,43,48

Beard, M.E. RI 57

Bearden, H.W. IC 77; RI 62,77

Beck, K.C. SP 17

Bell, O.G. AR 15(3)

Bermes, B.J. IC 13,18,37; RI 32

Berry, E.W. AR 9(2), 21/22(5)

Bibliographies SP 39,48

Big Cypress

Land use MS 50

Watershed MS 45

Biostratigraphy [See: Stratigraphy]

Birds B 44

Biscayne Aquifer RI 11,17,36

Bishop, E.W. RI 15; SP 8

Boggess, D.H. IC 62,75; RI 69; SP 49

Bond, P. BR 15,16,17; MS 112,126,127,

129; OFR 4,33,76; P 5,5rev.,8,10; SP 27

Bone Valley Formation RI 14 SP 2(1)

Boniol, D. SP 50

Bouguer anomaly MS 41,52,57

Boulder zone SP 20

Boyle, J.R. IC 94,95,96,97,99

Bradford County

Geology MS 79,88; OFMS 39; OFR 17

Mineral resources IC 100; MS 134

Soils AR 7(4)

Water resources IC 36,43 ; RI 35

Bradley, W.F. SP 17
Brevard County

Geology B 64; MS 80,85; OFMS 49;

OFR 55,69; RI 101

Mineral resources OFR 35

Water resources B 64; IC 11,32; MS 17,25;

RI 28

Bridges, W.C. IC 79; SP 16

Brodkorb, P. RI 14; SP 2(4)

Brooklyn Lake RI 33

Broward County

Geology MS 100; OFMS 64

Water resources IC 77; L 5; MS 29; RI 6, $17,20,36,51,55,65,70,77$

Brown, D.P. RI 68

Brown, D.W. IC 11,16,32; RI 28

Brown, E. IC 7,11; RI 10

Bryan, J.R. OFMS 89,90,91,92

Buie, B.F. SP 17

Bullen, R.B. RI 8

Burdette, C. RI 112

Burdette, K.E. OFMS 102; OFR 96

Burnson, T. RI 87

Bush, P.W. MS 54,69

Byers, W.C. AR 7(3)

C

Cagle, J.W., Jr. IC 36,43; RI 33,35

Calhoun County

Geology B 58; MS 90; OFMS 20; OFR 32

Geomorphology OFR 32

Paleontology B 53

Water resources IC 57; MS 10; RI 41

Caloosahatchee River B 40; IC 62

Calver, J.L. B 39; IC 2; MS 8

Campbell, K.M. IC 102; L 11,13; MS 146; OFMS $10,11,12,18,19,20,24,27,29,33,34$, $35,36,40,41,44,45,50,51,57,60,69,70,71,72$, $73,74,75,76,77,78,79,80,81,82,83 / 1-7$, $83 / 8-2,86.87,88,89,90,91,106,107$; OFR 6 , $7,8,10,11,13,30,35,37,39,41,49,56,62,102$, 104; RI 98; SP 27

Carlen, J.G. OFR 73

Carver, R.E. SP 17

Cathcart, J.B. MS 2

Causey, L.V. MS 74

Caverns L 10; OFR 23,47; SP 53

Cenozoic B 27

Ceryak, R. OFR 54; RI 87

Chaki, S.J. MS 52,57

Charlotte County

Geology B 43; MS 97,99,100; OFMS 59

Mineral resources SP 48

Paleontology B 43

Water resources IC 53; RI 78

Charlotte Harbor B 43

Chen, C.S. B 45

Chen Z.Q. OFR 69

Cherry, R.N. IC 26; L 9; MS 20; RI 42,56, 68

Chipola Formation B 53 
Chloride concentration IC 16; MS12,20

Choctawhatchee Formation Fossils B 3,4, 8,13

Choctawhatchee River AR 10/11(3)

Choquette, A.F. MS 140,142

Cichon, J.R. MS 151,152,153,154,155, 156,157 ; RI 104

Citrus County

Geology B 33; MS 99; OFMS 10; OFR 5 , 81; RI 9(2)

Hydrogeology OFR 81

Mineral resources IC 105; RI 9(2); MS 115

Paleontology B 35

Water resources $L 9$

Clapp, F.G. AR 2(1)

Clark, M.W. B 57; RI 92

Clark, R.R. SP 48

Clark, W.E. IC 36,43; RI 7(1),33,35,38

Clay County

Geology MS 89,93; OFMS 5

Mineral resources IC 46,100; MS 133

Water resources IC 35,36,43; RI 33,35

Clays AR 15(3); IC 2,46; OFR 14

Cleveland, M.A. OFR 2

Coastal studies

Datum planes OFR 73; SP 43

Erosion OFR 78

Marshes OFR 34

Plains SP 37

Water resources RI 54

Waves SP 41,45

Coble, R.W. MS 61

Coe, C. RI 86

Col, N. RI 99

Colbert, E.H. B 10(3)

Collier, C. SP 46

Collier County

Geology L 12; MS 100,101; OFMS 63; OFR 25,37

Mineral resources MS 120; SP48

Petroleum IC 104; RI 89

Water resources IC 29,51; OFR 37;

RI 11,31,63

Columbia County

Geology MS 88; OFMS 37; RI 30

Geomorphology AR 3

Mineral resources MS 136

Water resources RI 30

Conductance [See: Specific Conductance] MS 58

Congleton, B. SP 17

Conover, C.S. SP 13; MS 28,34,34(rev.), 72,124

Conrad, G.M. B 22(1)

Contamination [See: Pollution]

Cooke, C.W. AR 20(2); B 17,27,29

Cooper, H.H., Jr. IC 3; RI 7(2), 10 Cooper,

R. OFR 54

Copeland, R.E. B 66,69,70; SP 32,34,52

Coquina RI 88

Corals B 53,56

Cores IC 103; MS 111; OFR 37,56,62

Couto, P.A. SP 17

Cowart, J.B. SP 21(6); OFR 83; RI 100

Cox, N.H. B 2

Coquina RI 88
Corals B 53,56

Cores IC 103; MS 111; OFR 37,56,62

Couto, P.A. SP 17

Cowart, J.B. SP 21(6); OFR 83; RI 100

Cox, N.H. B 2

Crain, L.J. RI 80

Crane, J.J. RI 96

Cretaceous IC 60; RI 87; SP 15

Crooks, J.W. IC 32, 39; RI 26, 28

Cross, B. RI 101

Cushman, J.A. AR 12(5),13(3); B 4,9

Cypress domes AR 23/24(3)

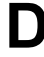

Dabous, A. A. OFR 83,87; RI 101

Dade County

Geology MS 101; OFMS 67,83/1-7,

83/8-12; OFR 48

Water resources IC 9; RI 4,17,24,45,47, $60,66,75$

Darby Spring SP 7

Datum planes OFR 73

Davis, B.E. RI 91(2),94(2)

Davis, D.R. IC 79

Davis, J. SP 50

Davis, J.H., Jr. B 25,30

Dee, L.L., Jr. SP 8,17

Deer Point Lake MS 38

DeHan, R. RI 111; SP 51,53

DeSoto County

Geology MS 80,97; OFMS 58,87; OFR 11

Water resources IC 53; RI 83

DeSouza, C.H. SP 17

Deuerling, R. MS 99; RI 90

Dever, G.R., Jr. SP 17

DeWitt, D. OFR 61

Diatomaceous earth AR 23/24(4)

Diatoms AR 23/24(5)

Dickey, J.B.R. AR 7(3)

Dion, N.P. IC 53; MS 27

Disney World [See: Walt Disney World]

Dissolved solids MS 14,77

Dixie County

Geology B 49; MS 79; OFMS 35; OFR 45

Geomorphology OFR 45

Dolan, E.M. SP 7

Dollar Bay Formation SP 15

Dolomite IC 104; RI 3,88

Donohue, J. F. RI 103

Drainage basins MS 28

Drought RI 26

DuBar, J.R. B 40,43

Duncan, J. B 64; MS 146; OFMS 53,56,63, 64, 66,67; OFR 29

Dunes B 23

Dunkle, D.H. SP 2(3)

Dunnellon Formation AR 6(3)

Duval County

Geology IC 64; MS 89; OFMS 4

Water resources IC 58,64,82; L 6; RI 43, 59

Dyer, S.B. OFMS 107; OFR 104

Dysart, J.E. MS 77

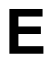

Earthquakes IC 93; OFR 40 East coast [See: Atlantic coast]
East Glades Agricultural Area RI 66

Echinoids B 34(2)

Econfina Creek basin IC 57; MS 10; RI 41

Ecosystem management areas MS 144

Eddy, W.H. RI 91(2)

Electrical conductance [See: Specific

conductance]

Elevations AR 5(2),12(3),17(3); B 32

Elsner, H. OFR 71

Enright, N.M. [See also: Martinez, N.]

OFR 54; RI 99

Environmental geology MS 78,79,80,84,85, $88,89,90,93,97,99,100,101$; SP 16,19,31, 33

Eocene

Fossils AR 21/22(5); B 35

Stratigraphy B 45

Petrology RI 9(2)

Erb, S.A. BR 29,30,31

Escambia County

Geology B 46; MS 78; OFMS 14; OFR 59

Geomorphology OFR 59

Mineral Resources OFR 75; SP 48

Petroleum IC 107

Water resources IC 30,50,74; L 3; MS 26; RI 40

Essig, D.F., Jr. IC 78; SP 16

Evans, G.S. OFMS 111,112; OFR 108,109

Evans, W.L. B 64; OFMS 93,94,97,104, 105,106; OFR 56,101,102

Evaporation potential MS 32

Everglades [See also: South Florida] AR 12(4); B 25

Exposures [See also: Outcrops] SP 5,30

E

Fair Point Peninsula RI 7

Fairchild, R.W. RI 59

Falling Waters State Recreation Area $\mathrm{L} 16$

Faulkner, G.L. B 31(Rev.); MS 55,63

Ferguson, G.E. B 31; RI 4

Fields, D.W. SP 17

Fischer, A.G. B 34(2); RI 9(2)

Fischler, C. B 68; OFR 100; RI 112,113,115

Fish SP 2(3)

Flagler County

Geology MS 93; OFMS 7; OFR 24;

RI 32

Mineral resources MS 127

Water resources IC 13,37,39; RI 32

Flippo, H.N., Jr. RI 53

Flood control RI 47

Floods IC 17,79

Flor, A.D. OFMS 101,102,103; OFR 94,96

Florida Bureau of Geology [See: Florida

Geological Survey]

Florida Caverns State Park L10; OFR 23

Florida Geological Survey BR 12,13,14,15, $16,17,18,19,20,21$; L 15,17; SP 26,42

Florida Keys L 14

Floridan Aquifer B 70; MS 16

Alachua County OFR 29

Brevard County B 64; MS 17

Chemical characteristics MS 27

Chloride MS 12

Dissolved solids MS $14 \quad E$

confina Creek basin MS 10

Fluoride MS 11,23 
Hardness of water MS 13

Hillsborough County MS 9

Orange County RI 72

Panhandle MS 10,11,23,86

Peace River basin MS 27

Peninsular Florida MS 92,95

Potable water MS 42,74

Potentiometric surface MS 4, 104,119, 138,140

Recharge MS 68,98; RI 72

Sediments OFR 29

Seminole County MS 5,68

Suwannee River Water Management

District OFMS 84

Top of MS 56,86,92,95,149; OFMS 84

Water quality MS 9,10,17

Floridan Plateau SP 21

Fluoride MS 11,23; RI 46,49

Foose, D.W. MS 107,118,124

Foraminifera AR 12(6),13(3); B 4,5(2),6,9, 16,19

Fossils [See: Paleontology]

Foster, J.B. IC 32,35,57,67,74; MS 46; RI 28,41

Fountain, R.C. SP 17

Fowler, G.D., III MS 160

Franklin County

Geology B 58; L 13; MS 84; OFMS 21; OFR 8

Mineral resources SP 48

Freedenberg, H. OFR 69; RI 101

Freiberger, H.J. MS 45

Freshwater MS 70,83,87,105,123,141,145

Fuller, W.R. SP 21(5)

Fuller's earth AR 2(3),4(3)

Furlow, J.W. SP 17

G

Gaboardi, M.M. OFMS 89

Gadsden County

Geology B 62; MS 90; OFMS 22; RI 16

Geomorphology B 10,26

Mineral resources AR 2(3)

Water resources IC 79

Galliher, C.F. RI 65

Gamma ray profiles OFR $26,42,81$

Gardner, J. B 14

Garnar, T. SP 17

Garrett, C.B. OFR 57

Gastropods B 3,12,14,15

Geochemistry RI 100; SP 34

Geography

Central Florida AR 13(4)

North Florida AR 6(4)

South Florida AR 18(2)

Geologic map of Florida MS 18,146,147, 150; OFR 80

Geological cross sections OFR 61, 81

Geological history SP 35

Geological resources MS 125; SP 35

Geologists

Licensing OFR 38

Geology of Florida B 29; MS 3,18,146,147; OFR 2,50,80; SP 5,39,44

Geomorphology B 41,51; OFR 18; SP 59
Geophysical explorations

Gamma ray OFR 26,42

Jacksonville IC 64

Neutron logs OFR 55

Georgia OFR 31

Geothermal SP 21

Gilchrist County

Geology B 49; MS 79; OFMS 36;

OFR 18; RI 99

Geomorphology OFR 18

Water resources RI 99

Glades County

Geology MS 80,100; OFMS 60,88;

OFR 30; RI 37

Water resources IC 59; RI 37,71

Goolsby, D.A. IC 58,74,82; MS 75,77

Goudarzi, G.H. SP 17

Grantham, R.G. IC 50; L 3,5 RI 40,45,51

Granulometry SP 40

Gravel [See: Sand and gravel]

Gravity [See: Bouguer anomaly]

Grayton Beach State Recreation Area L13

Green, R.C. BR 21; OFMS 83/01-07, 83/08-12,86,87,88,89,90,91,92,93,94,97, $98,99,100,101,102,103,104,105,106$, $107,108,109,110,111,112,113$; OFR 35,

$37,62,91,92,93,96,97,98,101,102,104$, $105,106,107,108,109,110$

Green Swamp IC 26; RI 42

Greenhalgh, T.H. BR 23; OFMS 95;

P 12,15

Gregory, J.T. B 22(2)

Gregory, W.K. B 5(1)

Griffin, G.M. SP 21(3)

Grosz, A.E. OFR 35,39,49

Groszos, M. OFMS 1,2,84; OFR 54

Groundwater [See also: Aquifers,

Artesian, Floridan Aquifer, Water]

B 11,70; IC 3; L 4; SP 4; RI 100

Alafia River basin MS 67; RI 49

Baker County RI 52

Bay County MS 46

Broward County IC 77; RI 6,20,77

Charlotte County IC 53

Chloride IC 16; MS 20

Collier County IC 29,51; RI 11,31

Columbia County RI 30

DeSoto County IC 53; RI 83

Duval County RI 43

Escambia County MS 26

Flagler County IC 13,37; RI 32

Glades County RI 37

Hardee County IC 53; RI 83

Hendry County RI 37

Highlands County RI 15

Hillsborough County RI 74,100

Lake County MS 44

Lake Okeechobee RI 2

Leon County B 47

Indian River County IC 18

Madison County B 61

Manatee County IC 6; RI 18

Martin County IC 12; RI 23

Nassau County IC 28; RI 43

Orange County MS 21; RI 5
Panhandle RI 29

Peace River basin MS 67; RI 49

Peninsular Florida B 1; IC 27; RI 10

Pinellas County IC 16; MS 20; RI 12

Polk County IC 23; RI 44

Public supply MS 102

Putnam County IC 15,37; RI 32

Quality RI 29; SP 32, 34

Saint Johns County IC 14,27; RI 32

Santa Rosa County MS 26; RI 7(1)

Sarasota County AR 23/24(6)

Seminole County IC 5,34; RI 1,27

Sources MS 124

South Florida B 27; RI 55

Volusia County IC 8; RI 22

Withdrawals MS 124; RI 49

Ground-penetrating radar (GPR) RI 122

Grubbs, J.W. MS 142

Gulf coast OFR 28; RI 29,56,95; SP 48

Gulf County

Geology B 58,63; L 13; MS84,90;

OFMS 23

Mineral resources SP 48

Paleontology B 16

Water resources IC 57; MS 10; RI 41

Gunter, H. AR 2(3), 3(3),4(2), 5(3), 7(2), 10/11(1), 12(3), 13(1,2), 14(1,2), 15(1), 16(1), 17(1,5), 18(1), 19(1), 20(1),

21/22(1-3), 23/24(1,3); BR 1,2,3,4,5,6,

$7,8,9,10,11,12$; B 2,32; IC 1

Gypsum SP 18

H

Hajishafie, M. MS 95

Haley, P.C. RI 16(3)

Hamilton County

Geology L 12; MS 88; OFMS 32; OFR 27; RI 87

Mineral resources MS 135

Water resources RI 87

Hamlin, H.P. IC 46

Hamon, J.H. B 44

Hampson, P.S. MS 109

Hampton, E.R. RI 60; MS 34,34(rev.),40

Hanan, R.V. MS 39

Hanna, G.D. AR 23/24(3)

Hannon, L.M. OFMS 103,104,105,106,

107,108; OFR 102,104,105

Hansard, P. RI 112

Hanshaw, B.B. SP 17

Hard rock phosphate [See also:

Phosphate]

AR 5(1)

Hardee County

Geology MS 80,97; OFMS 51,87

Water resources IC 53; RI 83

Hardee, J. RI 55

Harper, R.M. AR 3(4),6(4),7(2),13(4),

17(2),18(2)

Harris, W.B. SP 37

Hartwell, J.H. RI 47

Harvey, R.D. SP 17

Hatchett, L. P 7 
Hawthorn (Group and Formation)

B 10(3),59; OFMS 2 OFR 1,36; RI 91, 93,94

Hay, O.P. AR 8(2),9(2)

Hazlett-Kincaid, Inc. SP 54

Healy, H.G. IC $33,48,52,61,68,73,81,85$; MS 1,4,4(rev.),65,71,73,102,104

Heath, Ralph C. IC 5; RI 7(1),12; SP 4

Heath, Richard C. IC 25,69

Heavy minerals OFR $28,35,39,71$; RI 84,95

Hebets, C.L. OFMS 111,112; OFR 108, 109

Hendry, C.W., Jr. B 31(Rev.),47,50,52, 54(1); IC 10,21,89,90,91,92,94,95,96,97, 99; RI 16(1); SP 16,21

Hendry County

Geology MS 100; OFMS 62; OFR 37; RI 37

Petroleum RI 89

Water Resources OFR 37; RI 37,58

Henry, H.R. SP 21(2)

Hernando County

Geology B 54; MS 99; OFMS 41;

OFR 81; RI 34

Hydrogeology OFR 81

Mineral resources B 54; MS 114

Water resources IC 26; L 9; RI 34,42

Herring, R.R. IC 78

Hickman, R.C. IC 46

Highlands County

Geology MS 80; OFMS 52,88; RI 15

Water resources RI 15,19

Hillsboro Canal RI 55

Hillsborough County

Archeology RI 8

Geology IC 86; MS 97,99; OFMS 45;

OFR 6,61; SP 19

Mineral resources MS 2

Water resources IC 4,22,44,76,86;

MS 9,39,48,49; OFR 61; RI 21,25,68,

$74,82,100$; SP 19

Hoenstine, R.W. B 61; BR 24; L 11,12;

MS 113,114,115,116,117,120, 121,126,

$127,128,129,130,131,133,134,135,136$,

137; OFR 12,64,69,75; RI 88,90,93,101; SP $26,31,33$

Hollywood RI 77

Holmes County

Geology B 21; MS 90; OFMS 24

Mineral resources B 42,50

Hoover Dike RI 58

Hopkins, R.H. RI 3

Hornsby Springs SP 7

Horvath, G. RI 99

Howe, H.V. B 13,34(1)

Hoy, N.D. MS 5,7; RI 17

HUC units [See: Hydrologic units]

Hughes, G.H. MS 32,32(rev.),38,40,62,81;

RI 48,73,74,80,81; SP 16

Hull, J.E. IC 59 RI 66

Hull, R.W. B 31(Rev.); MS 91

Hunn, J.D. MS 48,49,60

Hurricane impact OFR 78

Hyde, L.W. L 4; MS 16,16(rev.)

Hydrogeological units SP 28

Hydrologic units MS 72,81
Ichetucknee Springs State Park L12;

RI 122

Indian River County

Geology IC 18; MS 80; OFMS 55;

OFR 55,69; RI 101

Paleontology AR 9,10,11,12; SP 10

Water resources IC 18; RI 80

Industrial minerals IC 102,105,109,112; MS 139; SP 17

Inglis Member B 34

Injection wells B 64; IC 74; OFR 83

Intracoastal waterway RI 38

Invertebrates SP 24

Irrigation MS 106,143

Irwin, G.A. MS 91

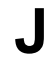

Jackson Bluff SP 14

Jackson Bluff Formation B 53

Jackson County

Geology B 37; L 10; MS 90; OFMS 25;

OFR 23; RI 16(1)

Geomorphology OFR 23

Mineral resources B 42; OFR 74

Paleontology B 16,22; SP 2

Water resources IC 57; MS 10; RI 41

Jefferson County

Geology B 48; MS 88; OFMS 31

Geomorphology AR 3

Mineral resources MS 129

Jim Woodruff Reservoir RI 16(1)

Johnson, R.A. IC 103; MS 111;

OFR 26,42,48,55; SP 30,50

Jones, G.B. AR 7(4)

Jones, G.P. SP 17

Jones, James B 66

Jordan, A.N. SP 39

Joyner, B.F. IC 41,47,56; L 8; MS 21,24; RI 50,53,71

K

Kaolin IC 2

Karst [See also: Caverns; Sinkholes;

Springs] SP 29,46,53

Kaufman, M.I. IC 53; MS 27,33,33(rev.), 35,35(rev.),37,37(rev.),51,51(rev.), 58,

58(rev.); RI 49

Kenner, W.E. IC 7,11,31,32,39,40; MS 22,

28,31,31(rev.),34, 34(rev.),66; RI 10,28

Keys [See: Florida Keys]

Keystone Heights RI 33

Kirk, N.M. AR 7(3)

Kirkland, R.T., Jr. L 2

Kissengen Spring RI 7(3)

Klein, H. IC 9,29; L 7; MS 42,53; RI 11,17, 24(1),37,60

Knapp, M.S. MS $79,80,88,92,97$; RI 87,88, 90
Knochenmus, D.D. $\quad$ MS 30,44; RI 57,72

Kohout, F.A. RI 19(1,2),24(4),47;

SP 21(2)

Kohpina, P. OFR 35

Kromhout, C. B 68; MS 150; OFMS 98,99, 100,101,104; OFR 93,94,98

Kurz, H. AR 23/24(2); B 23

Kwader, T. MS 86

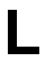

Laboratory methods OFR 64,79

Lachance, M.M. RI 107 [See also: Ladle, M.M.L.]

Ladle, M.M.L. RI 112 [See also:

Lachance, M.M.]

Lafayette County

Geology MS 79,88; OFMS 34; OFR 46

Geomorphology OFR 46

Water resources OFR 46

Lake basins AR 3(2),6(2)

Lake County

Geology MS 85,93; OFMS 9; OFR 81

Hydrogeology OFR 81

Water resources IC 26; MS 44,54; RI 42

Lake Istokpoga RI 19(1)

Lake Jackson RI 48

Lake Kerr RI 73

Lake Magdalene MS 49

Lake Minnehaha MS 54

Lake Okeechobee IC 59; RI 2,58,71

Lake Placid RI 19(2)

Lake Tarpon MS 60

Lake Thonotosassa MS 48

Lakeland Ridge RI 64

Lakes [See also: names of individual

lakes] AR3(2),6(2)

Depth IC 40

Stage characteristics IC 31

Water level MS 62,118; RI 74

Lamarche, A.G. OFMS 110,111,112; OFR $107,108,109$

Land, L.F. RI 67

Land, L.S. SP 17

Land pebble phosphates [See: Pebble phosphates]

Land use IC 72; MS 39,50,144; RI 47

Landfill [See: Sanitary landfill]

Lane, (B.)E. BR 18; IC 93; L14,15,16; MS $80,100,101,116,117,120,121,127$, $128,129,130,131,133,134,135,136,137$; OFR 20,40,52,53,58,75 P 6 RI 88,90; SP 8(rev.),23,29,31,33,35,42,47

LaPlace, N. OFR 49

Latimer, W.J. AR 7(2)

Lavender, J.A. IC 10,21

Leach, S.D. MS 72,87,103,105,108; RI 24(2,3,4),45,60

Lee, R.A. OFR 81

Lee County

Geology MS 97,99,100; OFMS 61; OFR 37; SP 49 
Mineral resources MS 130; SP 48

Petroleum RI 89

Water resources IC 7,62,75; RI 69; OFR 37; SP 49

Lehigh Acres Formation IC 104

Leon County

Geology B 47; MS 90; OFMS 28;

OFR 20; SP 14,16

Geomorphology AR 3,4; OFR 20

Water resources B 47; RI 48;SP 16

Leon Sinks Special Interest Area OFR 20

Leutze, W.P. IC 8

Leve, G.W. IC 15,27,28,37,58,64; L 6; MS 74; RI 32,43,52

Leverett, F. B 7

Levy County

Geology B 33; L 12; MS 79; OFMS 11; OFR 19, 81; RI 9(2)

Geomorphology OFR 19

Hydrogeology OFR 81

Mineral resources MS 116; RI 9(2)

Paleontology B 34,35

Li, L. OFR 81

Liberty County

Geology B 58; L 11; MS 90; OFMS 26;

OFR 9,43

Geomorphology OFR 43

Lichtler, W.F. IC 12,41,47; L 8; MS 21; RI 23,37,50,61

Limestone B 42,50,54; OFR 42; RI 3,9(2), 86,88

Lingham, C.W. B 31

Lithology OFR 47

Lithostratigraphy [See: Stratigraphy]

Llewellyn, TO. RI 94(2)

Lloyd, J.M. BR 20; IC 98,101,104,106, 107,108,110,111; L 19; MS 146; OFMS $33,69,70,71,72,73,74,75,76,77$, $78,79,80,81,82$; OFR 74 ; SP $32,34,46$

Long, L.T. SP 21(7)

Love, S.K. B 31; RI 4,13

Lowe, D.R. SP 17

Lowell, R.P. SP 21(7)

Lund, E.H. RI 16(2,3)

M

Macesich, M. OFMS 1; OFR 21

MacGill, P. RI 91(1)

MacKichan, K.A. L 2; MS 25; SP 13

Maddox, G. SP 32,34

Madison County

Geology B 61; MS 88; OFMS 27;

OFR 12

Mineral resources MS 121

Water resources B 61; OFR 12

Mahon, G.L. MS 140

Mammals AR 20(3); B 10(1); SP 6

Manatee County

Geology MS 97,99; OFMS 50,86,87

Mineral resources SP 48

Water resources IC 6,19; RI 18

Manatee Springs State Park L12

Mann, J.A. IC 76; L 9; RI 56

Mansfield, W.C. AR 10/11(5),15(2);

B 3,8,12,15,18
Marella, R.L. MS 123,141,143,145,149

Marianna Limestone Fossils B 5(2), 6

Marine resources

Atlantic coast OFR 35,39,69; RI 121

Mining OFR 57

Gulf coast RI 95

Heavy minerals OFR 35,39; RI 95

Petroleum IC 101,104; OFR 57

Sand and Gravel OFR 35,39

Marion County

Geology MS 79,93; OFMS 13; OFR 81;

SP 31

Geomorphology SP 31

Hydrogeology OFR 81

Mineral resources MS 117

Paleontology B 44

Water resources MS 55; RI 73; SP 31

Marls AR 16(2)

Marsh, O.T. B 46; IC 30; RI 29

Marshes OFR 34

Martens, J.H.C. AR 19(2)(3),21/22(4)

Martin County

Geology MS 80,100; OFMS 56;

OFR 51,69; RI 23, 101

Geomorphology OFR 51

Water resources IC 12; MS 80; RI 23,71; OFR 51

Martin, J.B. SP 16

Martinez, N. [See also: Enright, N.M.] OFMS 1

Matson, G.C. AR 2(1)

Maxwell, E.L. IC 66

Maul, T. OFR 49

May, J.P. SP 16

McCoy, H.J. IC 51; MS 29; RI 31,55,63,65

McDonald, H. SP 17

McGrain, P. SP 17

Means, G.H. B 66; BR 21; MS 146; OFMS $86,87,88,89,90,91$; OFR 85 ; P 14

Means, R.C. B 66; OFR 85

Meegan, R.P. B 66; OFR 85

Mekeel, D.E. SP 39

Melkote, S. RI 95

Menke, C.G. IC 36,43,44; RI 25,33,35

Mercury OFR 76

Meredith, E.W. IC 44; RI 25

Meyer, F.W. IC 26,59; RI 19(2),30,42,58, 66,75

Miami Limestone OFR 42,48

Miami River RI 45

Miller, J.A. MS 94

Milliken, D.L. RI 13

Mills, L.R. MS 67

Milton, C. B 55

Mineral industries

AR1(2),2(2),6(1),7(1),8(1),9(1),10/11(4), 13(2),14(1),15(1), 16(1),17(1),18(1),19(1), 20(1),21/22(1), 23/24(1); B 24,39; IC 66, $84,88,89,90,91,92,94,95,96,97,99,102$, 105,109,112; MS 8,139; SP 17

Mining and mineral resources B 30,39,50; IC 46,88,89,90,91,92,94,95,96,97,99,102, 105,109,112; MS 8,113,114,115,116,117, $120,121,126,127,128,129,130,131,133$, $134,135,136,137,139$; OFMS 1; OFR 28, $35,39,57,71,74,75$ RI 84,86,88; SP 8,18,22
Miocene

Choctawhatchee Formation $\mathrm{B} 3,8,13$

Fossils B 3,8,9,10,12,13; SP 2(2)

Hawthorn Group B 59

Lithostratigraphy OFR 31

Panhandle B 36

Southeastern U.S. SP 25

Missimer, T. B 65; MS 146; OFMS 59,61; SP 49

Moberg, M.W. AR 19(5)

Mollusks AR 10/11(5); B 14,15,18,35

Monitor wells IC 74

Monroe County

Geology L 14; MS 101; OFMS 66/1,66/2,83/1-7,83/8-12

Mineral resources SP 48

Paleontology B 19

Moodys Branch Formation B 34(2)

Mooney, C.N. AR 7(2)

Moore, W.E. B 37

Morrison, T.M. AR 7(2)

Mossom, S. AR 16(2),17(4),20(2)

Motz, L.H. RI 82

Musgrove, R.H. IC 17,30,36,43,50,57; L 3; RI 33,35,40,41

Mutis, E. SP 17

Myakka River Basin IC 56; RI 53

$\mathbf{N}$

Naples RI 11

Nason, L.F. OFMS 109; OFR 106

Nassau County

Geology MS 89; OFMS 3; OFR 15

Paleontology B 26

Water resources IC 28; RI 43

Natural resources [See also: Geography]

AR 18(2); B 17,25

Neel, H.E. RI 90

Neogene B 40,43,58; SP 37

Neutron Logs OFR 55

Nicol, D. RI 85

Nitrogen MS 75

Nocita, B.W. OFR 35,39,49

Norphlet Formation IC 107

0

Oakland Park RI 20

Observation wells MS 65

Ocala Group B 38

O'Carroll, T. B 61

Ochlockonee River AR 9(3),10/11(1);

RI16(3)

Odum, H.T. RI 9(1)

Offshore [See: Marine resources]

Ogden, G.M., Jr. RI 88,90

Oglesby, W.R. B 49; IC 88; MS 19,41,52, 57; SP 16

Oil [See: Petroleum]

Oil well locations MS 6

Okaloosa County

Geology MS 78; OFMS 16,89; RI 92

Mineral resources SP 48

Petroleum IC 107

Water resources IC 67 
Okeechobee County

Geology MS 80; OFMS 54,88

Water resources RI 71

Oklawaha Lakes area MS 69

Old Tampa Bay IC 76; RI 68

O'Leno State Park L12

Oligocene

Fossils B 5(1); SP 2(3)

Oliver, M.M. OFR 35

Olsen, S.J. SP 2(1),(2)(3);6,12

Olson, N.K. SP 17

Orange County

Geology MS 85; OFMS 47

Water resources IC 41,47; L 8; MS 21,24;

RI 5,50,72,79

Orthophosphate MS 33

Osceola County

Geology MS 80,85; OFMS 48

Osmond, J.K. SP 21(6)

Ostracods B 13,34

Outcrops [See also: Exposures] OFR 26; RI 86

Oyen, C. P 4

$\mathbf{P}$

Paleocene

Stratigraphy B 45

Paleoecology IC 100

Paleontology

Alachua County SP 2(4)

Birds B 44; SP 2

Bone Valley Formation SP 2(1)

Caloosahatchee River B 40

Echinoids B 34(2)

Eocene B 22(1)

Fish SP 2(3)

Hawthorn (Group and Formation) B 10(3)

Invertebrates SP 24

Mammals B 10; SP 6

Microfossils OFR 64

Miocene AR 8(3); B 10; SP 2(2)

Mollusks AR 10/11(5)

Moodys Branch Formation B 34(2)

Neogene B 40

Ocala Limestone AR 19(4)

Oligocene SP 2(3)

Ostracods B 13,34(1)

Pleistocene AR 8(2),8(3),8(4),9(2),

10/11(2);SP 36

Pliocene AR 8(3);SP 36

Quaternary AR 15(2)

Sample preparation OFR 64

Sites MS 125; OFR 63,65,66; SP 12

South Florida B 40,65; SP 36

Tertiary AR 15(2); B 34

Topographic map use OFR 67

Vero site AR 8(4),9(2); SP 10

Vertebrates AR8(2),8(3); B 10,22;

SP 2,6,10,12

Volusia County AR 10/11(5)
Moodys Branch Formation B 34(2)

Neogene B 40

Ocala Limestone AR 19(4)

Oligocene SP 2(3)

Ostracods B 13,34(1)

Pleistocene AR 8(2),8(3),8(4),9(2), 10/11(2);SP 36

Pliocene AR 8(3);SP 36

Quaternary AR 15(2)

Sample preparation OFR 64

Sites MS 125; OFR 63,65,66; SP 12

South Florida B 40,65; SP 36

Tertiary AR 15(2); B 34

Topographic map use OFR 67

Vero site AR 8(4),9(2); SP 10

Vertebrates AR8(2),8(3); B 10,22; SP 2,6,10,12

Volusia County AR 10/11(5)

Paleozoic IC 98

Palm Beach County

Geology MS 100; OFMS 65

Water resources MS 59; RI 13,55,58,

67,71

Palmer, K.V.W. B 35

Palynology IC 100; OFR 47

Panhandle [See also: individual county

names]

Apalachicola Embayment B58

Bouguer anomaly MS 52

Econfina Creek basin RI 41

Floridan Aquifer MS 11,86

Fossil hunter's guide OFR 63

Heavy minerals OFR 28

Limestone RI 86

Marine resources OFR 28

Papetti, L.W. OFR 35,39,49

Parker, G.G. B 27; RI 4

Pascale, C.A. IC 67,78; MS 70; RI 76; SP 16

Pasco County

Geology B 54; MS 99; OFMS 42;

OFR 81 ; RI 34

Hydrogeology OFR 81

Mineral resources B 54

Water resources IC 26; MS 47,61;

\section{RI 34,42}

Passerine birds B 44

Patterson, S. SP 17

Paul, D.T. OFMS 92,94,97,98,99,100,101, 102,106; OFR 91,92,93,94,96,102

Peace River Basin MS 27,67; RI 46,49

Peat AR 3(4),23/24(5); B 30; IC 100; OFR 4; SP 27

Pebble phosphate [See also: Phosphate] AR 7(2); MS 2

Peek, H.M. IC 4,6,19,22; RI 7(3), 18,21; SP 4

Peninsular Florida [See also: individual county names]

Biostratigraphy RI 93

Bouguer anomaly MS 57

Cretaceous IC 60

Floridan Aquifer MS 92,95
Floridan Aquifer MS 92,95

Fossil hunter's guide OFR 65

Hawthorn (Group and Formation) B 59;

OFR 36; RI 91,93,94

Geomorphology B 41,51; SP 5

Green Swamp area RI 42

Heavy minerals OFR 71; RI 84

Lithostratigraphy OFR 31,36

Trail Ridge RI 84

Water resources IC 27; RI 10,54, 56,61

Petroleum

Activities IC 54,55,63,65,71,80

Dollar Bay Formation SP 15

Exploration IC 1,42,45,49,101,106,107, 108,110,111; SP 9

Field maps MS 6

Lehigh Acres Formation IC 104

Norphlet Formation IC 107

Offshore IC 101,104; OFR 57

Policies IC 107

Production IC 42,45,49,101,104,106,107, 108,110,111; SP 9

Prospects AR 13(1),14(3),21/22(3); IC 49;

RI 89; SP 9,15

Regulations OFR 57

Reserves IC 107,108,110; OFR 44

Sunniland Formation RI 89

$\mathrm{pH}$, Streams \& canals MS 37

Phelps, D.C. OFR 99; RI 107,121

Phelps, G.G. MS 82,83

Phosphate AR 3(1),4(3),5(1),5(4),7(2);

IC 72; MS 33; OFR 14; RI 16(2),91,94; SP 18,22

Phosphorus RI 9(1)

Piezometric surface [See also:

Potentiometric surface] MS 1,4

Pinellas County

Geology MS 97,99; OFMS 44; OFR 61

Mineral resources SP 48

Soils AR 7(5)

Water resources IC 16; MS 20,60;

OFR 61; RI 12,68

Pirkle, E.C. B 52; RI 84

Pirkle, W.A. RI 84

Pithlachascotee River MS 61

Place names SP 1

Plantation Canal RI 36,70

Pleistocene

Fossils AR 8(1-4),9(2),10/11(2); B 6,18;

SP 6

Miami Limestone OFR 42

Tamiami Formation OFR 55

Pliocene

Fossils B6

Plio-Pleistocene B 43; SP 36

Polk County

Geology MS 80,85,97; OFMS 46;

OFR 13,81

Hydrogeology OFR 81

Mineral resources MS 2; SP 18

Paleontology B 19,22; RI 14; SP 2

Water resources IC 23,35,36,38;

RI $7,42,44,64$ 
Pollen [See: Palynology]

Pollution OFR 21; RI 70

Pontigo, F. RI 89

Ponton, G.M. AR 21/22(2,3),23/24(3);

B 5(2), 9

Potable water MS 42,74

Portell, R.W. P 4; SP 37

Potentiometric surface [See also:

Piezometric surface] MS 73,104, $119,138,140,149,151,152,153,154,155$, $156,157,158,159,160$

Pratt, R.W. SP 21(3)

Pride, R.W. IC 20,26,83; MS 28,36, 36(rev.); RI 26,42; SP 13

Public water supply IC 81 ; MS 91,102,108

Publications

Authoring OFR 53; SP 23

Editing OFR 52

List IC 87

Pumpage, Groundwater RI 49

Puri, H.S. B $36,38,49$; MS 3,18; SP5, 5(Rev.), 16,17,20

Putnam, A.L. RI 79

Putnam County

Geology MS 93; OFMS 6; RI 32

Mineral resources IC 46; MS 128

Water resources IC 15,37,39; RI 32

\section{$\mathbf{R}$}

Radon OFR 41

Ragland, J. IC 107

Rainfall

Annual and seasonal MS 40

Evaporation MS 32

Randazzo, A.F. B 54(2); RI 85

Ray, C.E. SP 3

Recharge MS 68,98; OFMS 69,70,71,72, $73,74,75,76,77,78,79,80$; RI 72

Reclamation IC 105

Reedy Creek Improvement Dist. RI 79

Reel, D.A. SP 21(3)

Reeves, W.D. B 42

Reichenbaugh, R.C. MS 47,48,49

Rich, F.J. IC 100

Richards, H.G. B 35

River basins MS 28

River pebble phosphates [See: Pebble

phosphates]

Roads AR 5(5); B 2

Roberts, Tina B 66

Robertson, A.F. MS 67; RI 64

Robertson, J.D. OFMS 89
Rocks and minerals SP 8,8 (rev.)

Basement B 55

Igneous and metamorphic B 55

Paleocene and Eocene B 45

Rodis, H.G. MS 59; RI 67

Rosenau, J.C. B 31(Rev.); MS 63,63(rev.), 96; SP 16

Rumenik, R.P. MS 122,142; SP 16

Runoff MS 22,81,122

Rupert, F.R. B 60,62,63; BR 19,23,26,27, 28; L 16,17,18; MS 117,125,134,135,146; OFMS 1,2,21,23,26,30,31,33,36,84; OFR $16,17,18,19,22,27,29,32,34,43,45$, 47,51,54,59,60,63,65,66,67,70,86,95; P 2,3,4,6,9,11; RI 99; SP 50

Ruskin RI 21

Russo, T.N. RI 70

8

Saint Andrews State Recreation Area L13

Saint George Island State Park L13

Saint Johns County

Geology OFMS 68; MS 89,93; RI 32

Mineral resources MS 126

Water resources IC 14,37,39; MS 89,93; RI 32

Saint Johns River IC 82 MS 25

Saint Johns River basin RI 54

Saint Johns River Water Management District SP 50

Saint Joseph Peninsula State Park L13

Saint Lucie County

Geology MS 80; OFMS 53; OFR 51,69

Geomorphology OFR 51

Water resources MS 80; RI 62; OFR 51

Saint Vincent Island OFR 8

Salt water intrusion IC 9,62,75; L 5,7; MS 47,59; RI 24(4),38,45,66,69

Sample preparation OFR 64

Sand RI 101

Sand and gravel AR 19(2); OFR 35,39,49; RI 84,90

Sanford, S. AR 2

Sanibel Island RI 69

Sanitary landfill MS 39; RI 68

Santa Rosa County

Geology B 46; MS 78; OFMS 15,89

Mineral resources SP 48

Petroleum IC 107

Water resources IC 30,50; MS 26; RI 7(1), 40

Sarasota County

Geology B 43; MS 97,99; OFMS 57,86, 87; OFR 10,56,60,62

Mineral resources SP 48

Paleontology B 43

Water resources AR 23/24(6), 23/24(7);

OFR 56; RI 38;

Savannas State Reserve OFR 51

Scaphopods B 3,12

Schmidt, W. B 57,58; L 10; MS 78,84,86, 90; OFR 3,9,23,38; RI 86,88,92; SP 44, 46,57

Schneider, J.J. RI 67

Schroeder, M.C. RI 13,17,37
Scott, G.W. IC 107

Scott, T.M. B 59,66; MS 80,85,89,93,95,130, 146; OFMS $3,4,5,6,7,8,9,10,12,13,14,15,16$, $17,22,25,28,32,37,38,39,43,47,48,49,51,53$, $54,55,56,59,61,62,65,68,69,70,71,72,73,74$, $75,76,77,78,79,80,81,82,83 / 1-7,83 / 8-12,86$, $87,88,89,91,92,94,97,98,99,100,101$;

OFR $1,15,31,35,36,37,41,50,56,62,66,80$, 85,91,92,93,94; RI 88,90,91(1),94(1),95;

SP $25,27,32,34,36,37,44,49$

Sea level [See also: Shorelines; Terraces] B 52; RI 103

Sea water intrusion [See: Salt water intrusion]

Seal, J.M. OFR 29

Sediment sampler OFR 88

Sedimentology SP 40,48

Seismicity IC 93; OFR 40

Sellards, E.H. AR 1,2(2,3),3(1-3),4,5, $6(1-3), 7(1,2), 8,9,10 / 11(1-3), 12(1,4,6)$, 14(2); B 1,2

Seminole County Geology MS 85; OFMS 43

Water resources IC 5,34; MS 5,68; RI 1,27,81

Sepulveda, A.A. MS 140,144,149

Shaak, G. SP 24

Shallow aquifer MS 53; RI 59

Shampine, W.J. MS 10,12,12(rev.),13, 13(rev.),14,14(rev.),15,17

Shattles, D.E. MS 9

Sherwood, C.B. IC 29; L 5; MS 29; RI 20 , 24(1-3), 51,65

Shorelines [See also: Sea level] MS 71

Shores [See also: Beaches, Waves]

SP $41,43,54$

Shufeldt, R.W. AR 9(2)

Sieving OFR 79,87

Simpson, G.G. AR 20(3); B 10(1)

Simpson, J.C. SP 1

Sinclair, W.C. IC 86; MS 110

Sinkholes [See also: Karst]

Development MS 110; SP 57

Geologic assessment OFR 72; SP 57

Index OFR 58

Leon Sinks OFR 20

Seminole County RI 81

Types MS 110

West-central Florida RI 39

Slack, L.J. MS 58,58(rev.),75,76,96; SP 16

Smith, D.L. SP 21

Smith, P.C. RI 12

Snake/Snapper Creeks RI 24

Snell, L.J. RI 54,80; MS 66

Snyder, S. OFR 35

Sohm, J.E. MS 107; SP 16

Soils [See also: individual county names] AR 4(1),7(4),7(5), 17(2)

South Florida [See also: individual county names] MS 19

Alafia River basin RI 46 Arcadia quadrangle OFMS 87,88 Bouguer anomaly MS 41 Brown Dolomite Zone IC 104 Caloosahatchee River area B 40 Cenozoic B 27 
Charlotte Harbor B 43

Dollar Bay Formation SP 15

Everglades B 25

Fossil hunter's guide OFR 66

Homestead Quadrangle OFMS 83

Lake Okeechobee RI 2

Lehigh Acres Formation IC 104

Miami Limestone OFR 42

Miocene SP 36

Natural resources AR 18(2); B 25

Paleontology B 40,43,65; SP 36

Peace River basin SP 27; RI 46

Phosphates RI 16(2)

Sarasota quadrangle OFMS 86,87

Stratigraphy B 40,43, 65; RI 89; SP 36

Sunniland Formation RI 89

Transmissivity SP 20

Vegetation B 25

Water control RI 60

Water quality MS 27; RI 46

Water resources B 27; MS 7,53; RI 2,4,55

Spechler, R.M. MS 106

Specific conductance MS 58

Spencer, S. B 60,61; IC 105,109,112;

MS 114, 115,116,117,120,121,126,127,128, $131,133,134,135,136,137,139$; OFR 5,12,

58,74,75; P 9,11

Springs [See also: Karst] B 31,31(Rev.),

66; OFR 85; OFMS 95; SP 51

Alachua County SP 7

Citrus County L 9

Darby Spring SP 7

Hernando County L 9

Hornsby Springs SP 7

Index MS 63

Kissengen Spring RI 7(3)

Polk County RI 7(3)

Sarasota County OFR 60

Submarine springs RI 7(2); SP 47

Wakulla Springs OFR 22,47

Warm Mineral Springs OFR 60

Water quality MS 96

West-central Florida RI 39

Sproul, C.R. B 47; IC 75; SP 21

STATEMAP Project OFMS $83,86,87,88$, $89,90,91,92$

Steinmetz, J.C. SP 17

Stewart, H.G., Jr. IC 23,38; RI 44

Stewart, J.W. MS 39,98,110; RI 56,74

Stone, R.B. MS 64; SP 16

Storms OFR 78

Stowasser, W.F. IC $84,88,89$

Stratigraphy AR 17(4); B 65; OFR 26

Alachua County OFR 41

Apalachicola embayment B 58

Biostratigraphy B 43; RI 93

Caloosahatchee River B 40

Dollar Bay Formation SP 15

Hawthorn B 59; RI 93

Hillsborough County OFR 61

Hydrostratigraphy OFR 61

Lithostratigraphy B 45; IC 103; MS

111; OFR 15,31,36,61

Ocala Group B 38

Okaloosa County RI 92

Panhandle B 58; RI 86
Pinellas County OFR 61

South Florida SP 36

Sunniland Formation RI 89

Streams

Chemical type MS 51

Color MS 35

Flow IC 69; MS 31,34,45,64,107,142;

RI 53

Nitrogen MS 75

Orthophosphate MS 33

$\mathrm{pH} \quad \mathrm{MS} 37$

Runoff MS 122

Specific conductance MS 58

Temperature MS 43

Stringfield, V.T. AR 23/24(4); B 11; IC 3; RI 1,2,7(2)

Structure AR 12,17(4)

Submarine springs [See also: Springs] RI 7(2); SP 47

Sulfate concentrations MS 15

Sullivan, G.V. RI 91(2),94(2)

Sumter County

Geology MS 99; OFMS 40; OFR 7,81;

RI 98

Hydrogeology OFR 81

Mineral resources MS 113

Water resources IC 26; RI 42

Sunniland Formation RI 89

Superconducting supercollider OFR 15

Surface water IC 7,20,25,39; MS 24,55,66, 76,77; RI 26

Surficial aquifer IC 86; RI 59

Sutcliffe, H., Jr. IC 56; RI 78

Suwannee County

Geology L 12; MS 88; OFMS 33; OFR 86; RI 87

Mineral resources MS 137

Water resources RI 87

Suwannee Limestone B 15,54

Suwannee River RI 87,96

Suwannee River Basin

Upper RI 87

Lower RI 96

Suwannee River State Park L12

Suwannee River Water Management District OFMS 1,2,84; OFR 54

Sweeney, J.W. IC $72,90,91,92$; SP 17,18 , 22

$\mathbf{T}$

Tamiami Formation OFR 55

Tampa Bay IC 76; RI 68

Tampa Bay Bypass Canal System RI 82

Tampa Formation (Tampa Limestone)

B 15,56

Tanner, W.F. OFR 79; SP 40

Tarver, G.R. IC 14,37; RI 32,36

Taylor, A.E. AR 7(3)

Taylor County

Geology MS 79,88; OFMS 29; OFR 70

Geomorphology OFR 70

Water resources IC 17

Taylor, K.L. B 64

Tectonics IC 98

Teel, J.R. MS 5
Terraces [See also: Sea level] MS 71

Pensacola Terrace B 7

Tertiary

Fossils B 18,34(1)

Tholeiite RI 97

Tibbals, C.H. MS 68

Tidal datums OFR 73; SP 43

Timmons, B.J. SP $16,17,18$

Toler, L.G. IC 57; MS 10,11,23; RI 41,46

Tootle, C.H. IC 107,108,110; OFR 44

Top of Floridan Aquifer MS 56,86,92,95; OFMS 84

Topographic maps OFR 67

Ordering [See page iv in this list]

Torreya State Park L 11

Trail Ridge IC 100; RI 84

Transmissivity zones IC 70 MS 132 SP 20

Trapp, H., Jr. L 3(Rev.)

Tucker, D.F. MS 40

$\mathbf{U}$

Union County

Geology MS 88; OFMS 39; OFR 16

Mineral resources MS 134

Water resources IC 36,43 ; RI 35

Unklesbay, A.G. RI 5; SP 4

Upchurch, S.B. B 66; SP 25,34

Uranium SP 22; RI 100

\section{V}

Vaughan, T.W. AR 2(1),19(4)

Vecchioli, J. MS 124

Vegetation B 23

North Florida AR 6(4)

South Florida B 25

Vernon, R.O. BR 13,14 B 21,24,31,33;

IC 70; MS 3,18,56; SP5,5(Rev.),16,17

Vero site AR 8(4),9(2),12(1),12(2); SP 10

Vertebrates B 10,22; SP 2,3,10,12

Visher, F.N. MS 32,32(rev.)

Volusia County

Geology MS 85,93; OFMS 8

Paleontology AR 10/11(5)

Water resources IC 8,24; MS 30;

RI 22,57 
Vorhis, R.C. RI 6

\section{W}

Wacassassa Flats RI 99

Wahl, F.M. SP 17

Waite, W.R. IC 105

Wakulla County

Geology B 58,60; MS 90; OFMS 30;

OFR 20,22,47

Water resources B 28; OFR 47,22; SP 47

Wakulla Springs OFR 22,47

Wakulla Springs Scientific Symposium SP 56

Walt Disney World RI 79

Walton County

Geology B 58; L 13; MS 78,90;

OFMS 17,89; OFR 3

Mineral resources B 50; SP 48

Paleontology B 12

Water resources IC 78; RI 76

Ward, E.L.M. MS 2

Warm Mineral Springs OFR 60

Washington County

Geology B 21; L 16; MS 90; OFMS 18;

OFR 95

Mineral resources B 42,50

Water resources IC 57; MS 10; RI 41

Waste disposal IC 70; MS 112; OFR 14

Waste, Liquid, Storage [See also: Injection wells] MS 94

Water

Biological characteristics RI 71; SP 53

Chemical characteristics MS 25, 27, 51;

RI 51,71,96

Color MS 35

Control RI 60

Data collection SP 11,13

Hardness MS 13

Levels IC 48,52,61,68,73,85; MS 62;

OFR 73; RI 48,74,75

$\mathrm{pH}$ MS 37

Phosphorus RI 9(1)

Potable MS 42,74

Quality IC 7; MS 9,10,17,51,55,76,82,91, 96; RI 9(1),29,51,57; SP 32,34,53

Resources L 1,2; RI 26; SP 4,11,44

Central and Northern B 61; RI 10

East Central RI 61

Middle Gulf RI 56

Northeast RI 54

Southeastern RI 4,60

Western Gulf Coast RI 29

Storage IC 70

Supply AR 4(2),5(3),21/22(2); MS 16,61,

$81,82,91,102$

Surface water MS 24,55,66,76,77

Temperature MS 25,43

Use MS 6,36,83,87,102,103,105,106,

$108,123,124,141,145$

Withdrawals MS 67,123,124,141,143,

145
Water-table contours MS 7

Waters, T.M. OFR 73

Waves

Breaking SP 41,45

Celerity SP 41

Height SP 41

Length SP 41

Weaver, C.E. SP 17

Weaver, J.L. SP 17

Weigel, R.D. SP 10

Weinberg, J.M. OFR 29,54

Weisbord, N.E. B 53,56

Weissinger, S. L 12; SP 26

Well Logs SP 50

Wells

Design IC 35

Freshwater MS 70

Monitor IC 74

Observation MS 65

Paleontology B16,19,20,26,28

Petroleum MS 6

Stratigraphy B 16,19,20,26,28; OFR 81

West coast [See: Gulf coast]

Wetlands MS 109

Wetterhall, W.S. IC 44; RI 25,34,39

White, K.M. OFMS 108,109,110; OFR

105,106,107

White, R. OFMS 1

White, W.A. B 41,51

Wickham, H.F. AR 12(2)

Willet, Alan B 66

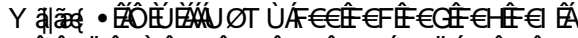

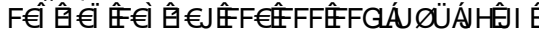

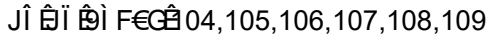

Williams, C.T. IC 105

Williams, H. OFR 69,79; RI 100

Williams, K.E. RI 85

Wilson, W.E. RI 83

Wimberly, E.T. IC 69

Windham, S. SP 16,21,22

Winston, G.O. SP 15,20

: RHEHU\$ $\$$ एा $\%$

Wood, A.E. B 10(2)

Woodard, H.J. IC 75

Woodville Karst Plain SP 46

Wright, A.P SP 16,19

Wyrick, G.G. IC 8, 24 RI 22

$Y$

Yoho, W.H. B 52; RI 84

Yon, J.W., Jr. B 48,49,50,54(1); IC 105!

MS 113,114,115,116,117,120,121,126, $127,128,130,131,133,146$; OFMS 31;

OFR 14; RI 16(1); SP 14,16

$\mathbf{Z}$

Zarillo, G. OFR 49

Zellars, M.E. SP 17

Zullo, V.A. SP 37 


\section{LIBRARIES HOLDING OUT-OF-PRINT FLORIDA GEOLOGICAL SURVEY PUBLICATIONS}

\section{Alabama}

The University of Alabama, Tuscaloosa

\section{Arkansas}

University of Arkansas, Fayetteville

\section{California}

Humboldt State University, Arcata; University of California, Berkeley; University of California, Davis; Natural History Museum of Los Angeles Co.; University of California, Los Angeles; U.S. Geological Survey, Menlo Park; California

Academy of Science, San Francisco; University of California, Santa Barbara; Stanford University, Stanford

\section{Colorado}

Colorado State University, Fort Collins Colorado School of Mines, Golden

\section{Florida}

Bartow - Florida Institute of Phosphate Research (FIPR) Library

Boca Raton - Florida Atlantic University Library

Brooksville - Southwest Florida Water Management District Library

Clearwater - St. Petersburg Jr. College

Coral Gables - University of Miami Library

Dania - Nova Southeastern University Library

Daytona Beach - Volusia County Library System

DeFuniak Springs - Walton County Public Library System

Deland - Stetson University Library

Fort Lauderdale - Broward County Library System

Fort Myers - Lee County Library System

Fort Pierce - St. Lucie County Library

Gainesville - University of Florida Library; Florida Museum of Natural History - Simpson Library

Havana - Northwest Florida Water Management District Library

Jacksonville - Jacksonville Public Library; Jacksonville University - Swisher Library; Museum of Science and History; University of North Florida Library

Lake Placid - Archbold Biological Station Library

Lakeland - Lakeland Public Library; Southeastern College - Steelman Media Center

Live Oak - Suwanee River Water Management District

Miami - Florida International University Library; Miami-Dade Public Library; University of Miami - RSMAS Library

Niceville - Okaloosa Walton Community College

North Miami - Florida International University - Biscayne Bay Campus 
Ocala - Marion County Public Library

Orlando - Orange County Library District; University of Central Florida Library

Palatka - St. Johns River Water Management District Library

Pensacola - University of West Florida

Punta Gorda - Edison Community College

St. Petersburg - Florida Marine Research Institute Library; St. Petersburg Public Library

Sarasota - Sarasota County Public Library; University of South Florida - Sarasota Campus

Tallahassee - Florida State University; Library State Library of Florida; Tallahassee Community College Library

Tampa - Tampa-Hillsborough County Library; University of South Florida Library

West Palm Beach - West Palm Beach Public Library; South Florida Water Management District

Winter Park - Rollins College Library

\section{Georgia}

Fernbank Science Center, Atlanta; Georgia State University; Atlanta Environmental Protection Agency, Atlanta; University of Georgia Libraries, Athens; Thomas University, Thomasville

\section{Illinois}

University of Chicago, Chicago Northern Illinois University, DeKalb

lowa

lowa State University, Ames University of lowa, lowa City

\section{Kansas}

Kansas Geological Survey, Lawrence

\section{Kentucky}

Kentucky Geological Survey, Lexington

\section{Louisiana}

University of Louisiana, Lafayette; University of New Orleans, New Orleans; Tulane University, New Orleans

\section{Maryland}

Maryland Geological Survey, Baltimore

\section{Massachusetts}

University of Massachusetts, Amherst; Harvard University, Cambridge; Massachusetts Institute of Technology; Cambridge Smith College, Northampton

\section{Michigan}

University of Michigan, Ann Arbor

\section{Minnesota}

University of Minnesota, Minneapolis

Mississippi

Department of Environmental Quality, Jackson; Mississippi State University

\section{Missouri}

Linda Hall Library, Kansas City; Washington University, St. Louis

\section{Nebraska}

Chadron State College, Chadron; University of Nebraska, Lincoln

\section{Nevada}

University of Nevada, Reno 


\section{New York}

State University of New York, Binghamton; Cornell University, Ithaca; American Museum of Natural History, New York; State University of New York, Stoney Brook

\section{North Carolina}

University of North Carolina, Chapel Hill

\section{Ohio}

Ohio University, Athens Cleveland Public Library, Cleveland Ohio Department of Natural Resources, Columbus Ohio State University, Columbus Miami University Library, Oxford

\section{Oklahoma}

Oklahoma State University, Stillwater

\section{Oregon}

Oregon State University, Corvallis

\section{Pennsylvania}

Franklin \& Marshall College, Lancaster The Academy of Natural Sciences, Philadelphia Carnegie Library,

Pittsburgh University of Pittsburgh, Pittsburgh Pennsylvania State University, University Park

\section{Rhode Island}

Brown University, Providence

\section{South Carolina}

Clemson University, Clemson

Texas

University of Texas, Austin; Texas A \& M University, College Station; Dallas Public Library, Dallas

\section{Utah}

Brigham Young University, Provo

\section{Virginia}

American Geological Institute, Alexandria; Virginia Tech., Blacksburg; Virginia Department of Mines, Minerals \& Energy, Charlottesville; U.S. Geological Survey, Reston; College of William and Mary, Williamsburg

\section{Washington, DC \\ Library of Congress}

Wisconsin

University of Wisconsin, Madison; Milwaukee Public Museum, Milwaukee; University of Wisconsin, Milwaukee

\section{Wyoming}

Geological Survey of Wyoming / University of Wyoming, Laramie

\section{INTERNATIONAL LIBRARIES}

\section{Australia}

University of Queensland, St. Lucia, Queensland

\section{Canada}

Geological Survey of Canada, Ottawa, Geological Survey of Canada, Vancouver, B.C.

\section{England}

British Geological Survey, Nottingham British Library, West Yorkshire

France

Bureau de Recherches Geologiques et Minieres, Bibliotheque Centrale, Orleans

Italy

Presidenza del Consiglio del Ministri, Rome 
Philippines

Mines \& Geosciences Bureau, Surigao City

Puerto Rico

Puerto Rico Bureau of Geology, Puerta de Tierra

\section{Sweden}

Sveriges Geologiska Undersokning, Uppsala 


\section{FLORIDA GEOLOGICAL SURVEY STAFF DIRECTORY}

Guy H. Means, Director and State Geologist

Main phone 850.617.0300.

Last four digits of main-office staff phone numbers shown below.

Full numbers are provided for satellite office staff.

ADMINISTRATION SECTION

Sarah Erb, OMC Manager, 0333

Traci Billingsley, Gov. Op. Consult., 0339

Mary Esposito, Admin. Assistant, 0336

Kathryn Armstrong, Admin. Assistant, 0321

Mabry Gaboardi Calhoun, OPS Env. Consultant, 0342

APPLIED GEOSCIENCE SERVICES SECTION

Mary Beth Lupo, Professional Geologist Administrator, 0323

Scott Barrett Dyer, Professional Geologist, 245.3120

Tommy Neet, Env. Specialist, 0330

Gary Fowler, Env. Consultant, 0313

Ericka McMahan, OPS Geologist, 0310

\section{GEOLOGICAL INVESTIGATIONS SECTION}

Clint Kromhout, Professional Geologist Administrator, 0332

Rick Green, Professional Geologist, 0318

Nickolaus Hall, Env. Specialist, 245.3122

Crystal Hebets, Env. Specialist, 0302
Christopher Williams, Professional Geologist, 0317

Casey Albritton, Env. Consultant, 0330

Jade Greene, Env. Specialist, 245.3133

Brittany Duffey, OPS Env. Consultant, 0331

\section{GEOSCIENCE INFORMATION AND DATA MANAGEMENT SECTION}

Alan Baker, Professional Geologist Administrator, 0337

Jan DeLaney, Gov. Op. Consult., 0329

Kathryn Etheridge, Archivist, 0316

Garrett Evans, Env. Specialist, 0311

Amanda Kubes, Env. Specialist, 0328

Michelle Ladle, Professional Geologist, 0314
Keith Wood, Env. Specialist, 0325

Emilie Speer, OPS Env. Specialist, 0338

Zanti Rains, OPS Env.

Melissa Pearson, OPS Env. Specialist, 0331

Dylan Cook, OPS Env. Specialist, 0311

Caroline Reeves, OPS Env. Specilaist, 0306

\section{GEOLOGIC SAMPLE ACQUISITION AND MANAGEMENT}

Dave Paul, Professional Geologist Administrator, 850.245.3131

Ben Davis, Env. Consultant, 245.2384

Nicholas Bloodworth, Eng. Specialist, 245.3134

Edward Chelette, Env. Specialist, 245.3121
William Gladwin, OPS Geologist, 245.3082

Jesse Hurd, Env. Specialist, 245.3124

Robert Speirs, Eng. Technician, 245.3132

Angelique Tran, Env. Specialist, 245.3125 